


\section{Geologic Structures in the Gulf of Mexico Basin}

By LOUIS E. GARRISON and RAY G. MARTIN, JR.

GEOLOGIGAL SURVEY PROFESSIONAL PAPER 773

Investigations conducted jointly with

the U.S. Naval Oceanographic Office

The principal structural features of the Gulf of

Mexico are illustrated by seismic-reflection profiles, accompanied by a discussion of the geology of the gulf basin

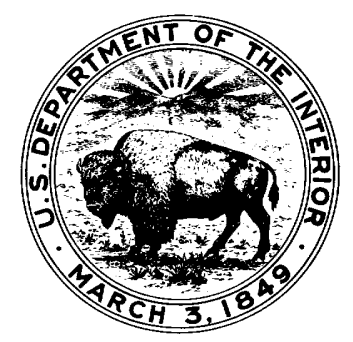

UNITED STATES GOVERNMENT PRINTING OFFICE, WASHINGTON : 1973 


\section{UNITED STATES DEPARTMENT OF THE INTERIOR}

ROGERS C. B. MORTON, Secretary

\section{GEOLOGICAL SURVEY}

V. E. McKelvey, Director

Library of Congress catalog-card No. 73-600145

For sale by the Superintendent of Documents, U.S. Government Printing Office Washington, D.C. 20402 - Price $\$ 2.00$ domestic postpaid or $\$ 1.75$ GPO Bookstore Stock Number 2401-00366 


\section{CONTENTS}

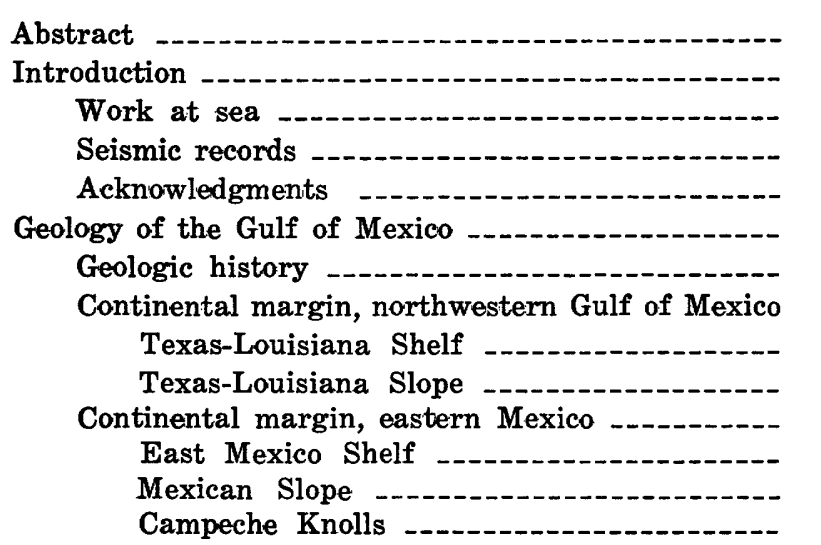

\begin{tabular}{|c|c|c|}
\hline Page & & Page \\
\hline 1 & Geology of the Gulf of Mexico-Continued & \\
\hline 2 & Eastern Gulf of Mexico carbonate provinces -- & 18 \\
\hline 5 & Banco de Campeche & O \\
\hline 5 & West Florida Margin & 18 \\
\hline 0 & Continental margin, northeastern Gulf of Mexico & 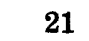 \\
\hline 7 & Central Gulf of Mexico basin & \\
\hline 8 & Continental rise & 2 \\
\hline 8 & Sigsbee Plain & 2 \\
\hline 9 & sippi Fan & 2 \\
\hline 9 & n limits of the Gulf of Mexico & 2 \\
\hline 9 & d of the gulf & 2 \\
\hline 12 & of Florida & 2 \\
\hline 12 & Yucatan Channel & 2 \\
\hline 14 & ions & 2 \\
\hline 15 & - & \\
\hline
\end{tabular}

\section{ILLUSTRATIONS}

Plate

Figure
1. Selected seismic-reflection profiles, Gulf of Mexico

Page In pocket

1. Bathymetric map of Gulf of Mexico showing major physiographic features

2. Map of Gulf of Mexico showing geophysical cruise tracks -.

3. Diagram showing USNS Elisha Kane and relative towing position of equipment

4. Tectonic sketch map of northwestern Gulf of Mexico and adjacent coastal plain -

5. Tectonic sketch map of southwestern Gulf of Mexico and adjacent regions of Mexico

6. Map showing distribution and morphological classification of diapirs, Golfo de Campeche

7. Tectonic sketch map of eastern Gulf of Mexico

8. Seismic-reflection profiles, Texas-Louisiana Shelf _-_...-...--

9. Seismic-reflection profiles, Texas-Louisiana Shelf _._._-_-_-_

10. High-resolution profile, Texas-Louisiana Shelf _.........11-13. Seismic-reflection profiles showing-

11. Continental slope, northwest Gulf of Mexico

12. Sigsbee Escarpment

13. Detail of Sigsbee Escarpment

14. Seismic-reflection profile and high-resolution profile, lower continental slope, northwest Gulf of Mexico

15. High-resolution profiles, continental shelf and slope, northwest Gulf of Mexico

16. Seismic-reflection profiles, East Mexico Shelf and upper slope, western Gulf of Mexico

17. Seismic-reflection profiles, continental shelf and slope, Golfo de Campeche -.......-.

18. High-resolution profiles, continental shelf and slope, Golfo de Campeche 
FIgURES 19-21. Seismic-reflection profiles showing-

19. Mexican Ridges - 54

20. Lower continental slope, western Gulf of Mexico -- 56

21. Lower continental slope, Golfo de Campeche _.....- 58

22. Seismic-reflection and high-resolution profiles, Banco de

Campeche -

23-34. Seismic-reflection profiles showing-

23. Campeche Escarpment and Canyon, southwestern Gulf of Mexico

24. South Florida shelf

25. West Florida Escarpment

26. Northeastern Gulf of Mexico

27. De Soto Canyon, northeastern Gulf of Mexico -...--

28. Knolls and domes in abyssal Gulf of Mexico

29. Challenger Knoll, central Gulf of Mexico

30. Mississippi Fan, eastern Gulf of Mexico _..........

31. Jordan Knoll and Catoche Tongue, southeastern Gulf of Mexico

32. Straits of Florida

33. Tortugas and Agassiz Valleys, Straits of Florida ---

34. Yucatan Channel and western Straits of Florida -...- 


\title{
GEOLOGIC STRUCTURES IN THE GULF OF MEXICO BASIN
}

\author{
By Louis E. Garrison and Ray G. Martin, Jr.
}

\section{ABSTRACT}

In 1969 , more than 25,000 kilometers of continuous seismicreflection profiles were recorded during a joint U.S. Geological Survey and U.S. Naval Oceanographic Office geophysical-geological survey of the Gulf of Mexico conducted aboard the USNS Elisha Kane. This report presents a selection of 63 profile segments that exemplify the variety of structural and stratigraphic features that characterize the several geologic provinces of the gulf.

The Gulf of Mexico is a relatively small mediterranean sea covering an area of more than 1.5 million $\mathrm{km}^{2}$. Its opening to the Atlantic Ocean and Caribbean Sea is confined into two narrow passages, the Straits of Florida and the Yucatan Channel, by the Greater Antilles Ridge from which Cuba emerges. The gulf is underlain by oceanic crust which is depressed substantially below the levels of equivalent crustal layers in normal ocean basins. In contrast to the neighboring Caribbean Sea, whose margins have either been created or highly modified by plate-tectonic processes, the gulf appears to have drifted passively with North America, gaining its present form wholly from a combination of sedimentary and intrabasin tectonic processes.

Present available evidence suggests that the gulf is a relatively old ocean basin, possibly in existence as early as Pennsylvanian time, although its size has been considerably diminished since the close of the Cretaceous by an overwhelming influx of terrigenous sediments in the northern sector. During the clastic deposition in the north, the carbonate platforms of Florida and Yucatan continued their upward growth in pace with subsidence and maintained their tops near sea level. The continental margin of the gulf has thus developed into two separate geological provinces, (1) a southeastern region of shallow carbonate banks and (2) a northwestern region of terrigenous embankments.

The vast wedge of terrigenous sediments which composes the northern continental margin is highly distorted by intrusions and massive uplifts of Louann Salt (Jurassic?). The diapiric salt features that dot the continental slope from the Mississippi Fan to northeast of Tampico end along the foot of the slope in massive salt fronts which produce the Sigsbee Escarpment in the northern part of the gulf and the Rio Grande escarpment in the northwestern part. These salt fronts are believed to be products of the seaward migration of salt from separate basins. A broad area of scarce, widely spaced domes in the northwest corner of the gulf separates the two areas of major slope diapirism. Its anomalous character may reflect the seaward extension of the San Marcos arch, a region of thin or absent salt which crosses the coastal plain of southern Texas.

The continental margin of the western gulf, where the coastal plain is constricted by the flanking Sierra Madre Oriental, is the narrowest in the basin. The structural framework of the submerged margin follows closely the pattern of alternating arches and basins known in the coastal plain from the Rio Grande in the north to the Banco de Campeche in the south. Off northeastern Mexico, continental-slope structures are a continuation of the saltcontrolled features of the Texas-Louisiana Slope. A similar province of salt structures deforms continental-margin sediments in the Golfo de Campeche and stretches northward into deep water from the salt anticlines of the Isthmian saline basin. Between these two provinces of salt diapirs are the Mexican Ridges, a region of linear anticlinal folds whose trends are essentially parallel to the strike of the coast. The folds have been attributed to initial deformation of salt under sedimentary load, but an alternative hypothesis is that they are the result of a decollement. Negative Bouguer anomalies associated with some of the folds indicate a low-density core and support a salt-origin hypothesis, but the lobate regional pattern of ridges suggests submarine landsliding.

A morphologic grouping of diapiric forms in the Golfo de Campeche indicates that the Sigsbee Knolls, the continental slope diapirs, and the salt structures of the Isthmian saline basin stem from separate salt masses. This in turn suggests that they may have formed in a series of salt basins ringing the ancient Yucatan Peninsula but sheds no light on the question of whether the salt formed in place or migrated outward from beneath the limestone bank.

The eastern and southern continental margins of the gulf are formed by the massive carbonate banks of Florida and Yucatan. They are bordered by impressive escarpments which impart to the eastern gulf a geometrically simple pattern of bold topographic elements. The West Florida Escarpment is formed by the seaward face of a Lower Cretaceous barrier reef which stretches discontinuously northward from the Straits of Florida to the terrigenous margin of the northeast gulf. The northeastern face of the Campeche Escarpment is likewise formed by a barrier reef which appears to be of limited extent and is not seen southward into the. Yucatan Channel or westward around Banco de Campeche. Similar Lower Cretaceous reefs are known to encircle the northern and western coastal-plain regions and to form the Golden Lane atoll in Mexico and the smaller Jordan Knoll atoll in the southeastern gulf. 
In the northeastern gulf, the Cretaceous reef of the Florida Escarpment and the overlying beds of the upper slope are being progressively buried beneath an advancing wedge of upper Tertiary clastic rocks from the northwest. The junction of these disparate elements forms the De Soto valley and, at least in part, the De Soto Canyon. Diapiric features clustered in the vicinity of De Soto Canyon are believed to represent the easternmost occurrence of Louann Salt in the northern gulf.

The principal features of the central region of the Gulf of Mexico are the continental rise, the broad, flat-floored Sigsbee Plain, and the Mississippi Fan. The continental rise is at the foot of the Sigsbee Escarpment and stretches westward from the Mississippi Fan to northern Mexico. It is underlain by successive wedges of sediment deposited as gravitational flows and interbedded turbidites originating on the continental slope. The Sigsbee Plain is an almost featureless expanse of deep sea floor interrupted only by the Sigsbee Knolls in its central sector. It is underlain by more than $300 \mathrm{~m}$ of near-horizontal Pliocene-Holocene turbidites and pelagic oozes beneath which Miocene and older beds dip northwest toward the Sigsbee Escarpment. The dominance of Quaternary deposition by the Mississippi River distributary system in the east-central gulf is manifested by the Mississippi Fan which covers more than $160,000 \mathrm{~km}^{2}$ of gulf floor. Its axis is alined with the strike of the Mississippi Trough which is southwest of the delta front, from which fan deposits extend southeast more than $600 \mathrm{~km}$ to the deepwater approaches of the Straits of Florida and Yucatan Channel. In the central gulf the fan deposits merge with horizontally layered deposits of the plain.

The southeasternmost sector of the gulf is an area of complex and little known geology in which the gulf opens to the Atlantic Ocean and Caribbean Sea through the relatively narrow Straits of Florida and Yucatan Channel. Across these openings occurs an abrupt structural transition from the relatively simple framework of the gulf to the complex Laramide tectonic front of Cuba. The exact nature of the gulf-Caribbean juncture is unknown, but it is believed to be a major fault zone of either normal or strike-slip displacement. The origin of the Straits of Florida is attributed to a combination of tectonic and sedimentary processes active since at least Jurassic time.

\section{INTRODUCTION}

The Gulf of Mexico is probably one of the most intensely studied small ocean basins in the world, where new insight has been gained on a host of complex geologic problems. For example, drilling has shown that the Sigsbee Knolls, whose origin was a subject for speculation for years, are underlain by salt diapirs. Geophysical studies have shown that the great escarpments that separate continental slope from basin floor throughout much of the gulf are underlain by massive salt in the northern gulf and by carbonate reefs in the south and east. The general locations of some of the major structural and physiographic features are now well known (fig. 1), but the mapping of such broad geologic provinces has not diminished geological interest in the Gulf of Mexico. On the contrary, the stage is now set for future studies which promise to yield a better understanding of fundamental earth processes operative in the region. If the investigations of the past have provided a geologic framework, the studies of the future will cover it with a rich fabric of detail. It was in the hope of bridging the gap between framework and fabric that the survey of the Gulf of Mexico by the USNS Elisha Kane was undertaken in 1969.

Of the many excellent earlier studies, none were on a gulf-wide scale, and most were concerned with specific problems in relatively restricted areas. It therefore seemed desirable to tie together this patchwork of studies with a net of geophysical tracks and sample lines which would allow extrapolation between older surveys and which would extend geologic coverage from the continental margins to the distal parts of the gulf. Such an investigation became possible in 1969 when the U.S. Naval Oceanographic Office and the U.S. Geological Survey agreed to undertake a cooperative geophysical-geological study of the Gulf of Mexico.

Data collection for the joint program began in January and ended in September 1969 and was accomplished in two phases. The first phase, which started from Corpus Christi, Tex., was the collection of geophysical data. It was divided into a shakedown track (leg A) and three consecutive cruise legs, each of approximately 22 days duration (fig. 2, B, C, and D). The data included continuous deeppenetration seismic-reflection profiles, continuous high-resolution shallow-penetration profiles, precision depth recordings, measurements of magnetic intensity, and continuous measurements of seasurface temperatures and salinities. Shipboard gravity measurements were made on leg D only. The second phase, consisting of three additional cruise legs of 21 days each, was designed principally for sediment studies. It was completed with the cooperation and assistance of scientists from Texas A. \& M. University, the University of Texas, Rice University, Louisiana State University, Florida State University, and the University of Mexico.

Possibly one of the most exciting results of the geophysical cruises was the assemblage of more than 25,000 kilometers of continuous seismic-reflection profiles which provide a vivid picture of the structure of the Gulf of Mexico. These records provide a tie between regions heretofore only described separately, and, being continuous over the length and breadth of the gulf, they permit long-distance correlations not previously apparent. Their excellent 


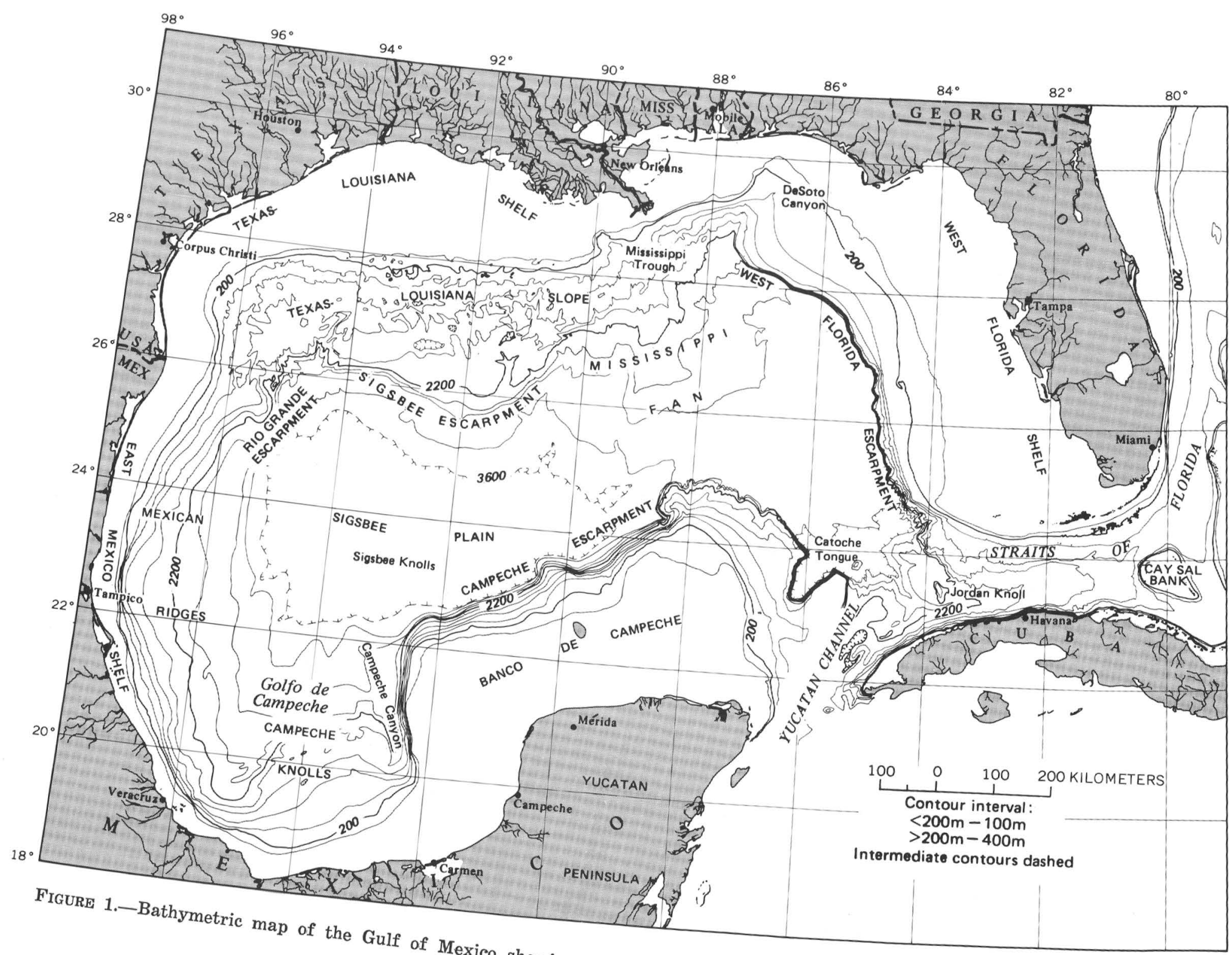

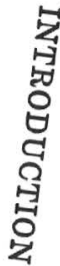
Uchupi (1967). 


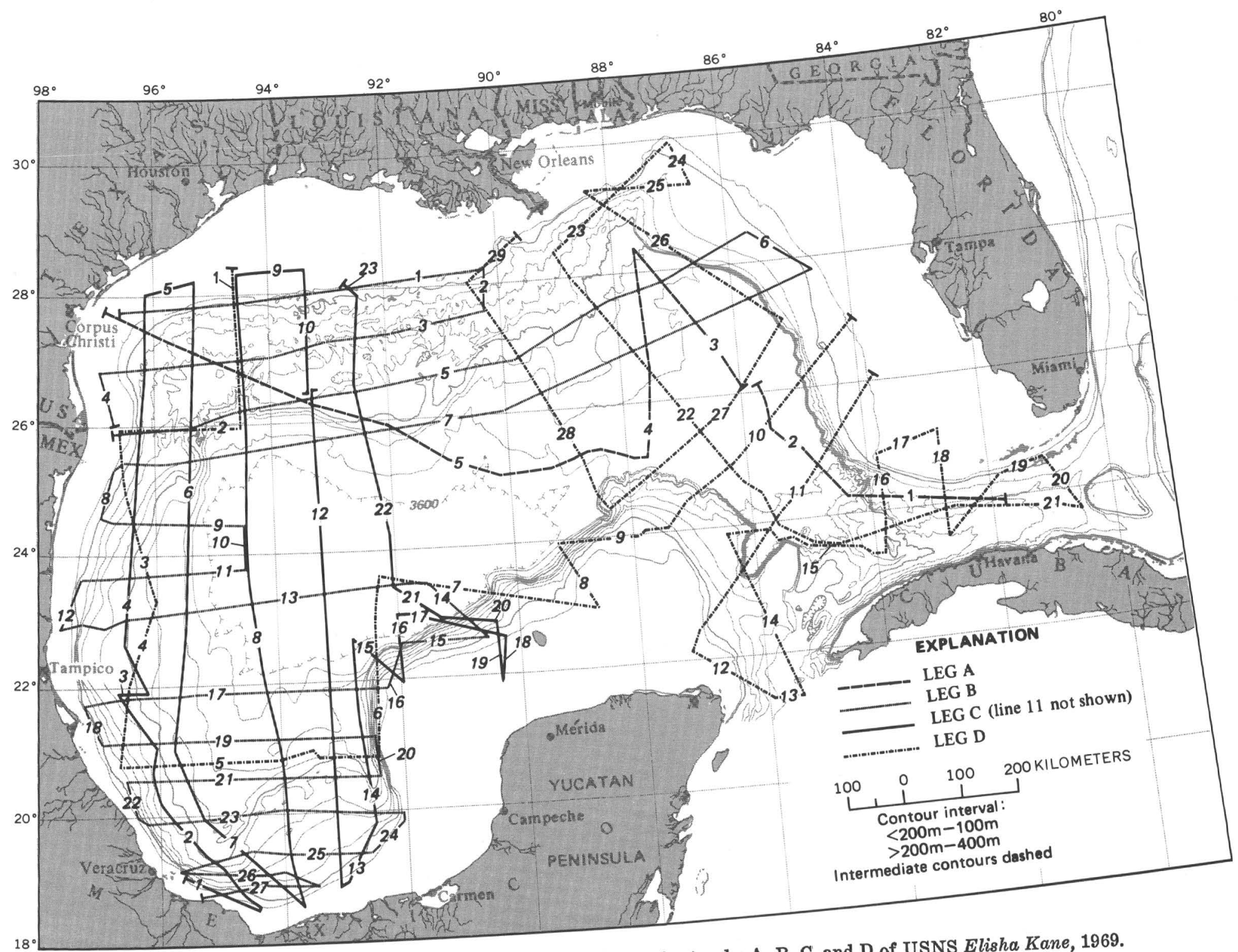

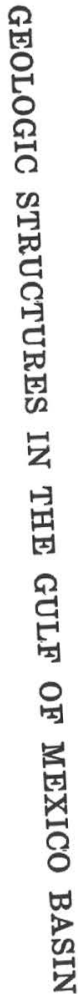

FIGURE 2.-Map of Gulf of Mexico showing geophysical cruise tracks A, B, C, and D of USNS Ehisha Kane, 
quality and ideal scale yield a wealth of structural detail found in few previous reports from this area, and, supplemented by the high-resolution $3.5 \mathrm{kHz}$ (kiloHertz) subbottom profiles, they clearly illustrate the deformation of sedimentary beds under a variety of dynamic conditions which now exist in the Gulf of Mexico.

For those who desire more detail, the complete collection of seismic records has been made available on microflm. ${ }^{1}$ However, for those whose requirements are less comprehensive, this report is presented as a summary, for which a selection of 63 seismic-profile segments has been assembled to exemplify and highlight the geologic structures that characterize the various structural provinces of the gulf.

The following text material contains a discussion of the seismic-profiling equipment and the resulting profiles. This is followed by a brief summary of the geology of the Gulf of Mexico which, it is hoped, will serve as a framework in which to fit the profile illustrations. Although useful in visualizing most of the main structures described in the text, the profiles are not specifically discussed in the main text and can be viewed independently. They are grouped in a special section and discussed in accompanying captions.

\section{WORK AT SEA}

The work at sea was conducted aboard the USNS Elisha Kane (T-AGS 27) a 290-foot $(88.8 \mathrm{~m}) 2,897$ ton oceanographic vessel operated by the Military Sea Transportation Service (MSTS, now Military Sealift Command) under the technical direction of the U.S. Naval Oceanographic Office. The ship's position along geophysical tracks was determined simultaneously by several systems. Loran-A, Omega, and the celestial sextant were effective over the entire Gulf of Mexico, whereas Loran-C was limited to the northern part. For leg D, principally in the eastern gulf, a satellite navigation system (Magnavox model $\mathrm{MX} / 702 / \mathrm{HP})^{2}$ was used. Radar was useful when the shoreline was within range. We estimate that minimum positional error varied from about $200 \mathrm{~m}$ for the satellite system to about $500 \mathrm{~m}$ for positions based on Loran-A. Maximum positional errors of as much as $5 \mathrm{~km}$ were noted south of lat. $20^{\circ} \mathrm{N}$. in the Golfo de Campeche where Loran-A was least effective.

\footnotetext{
1 National Geophysical and Solar-Terrestrial Data Center, Environmental Data Service, U.S. Department of Commerce, Boulder, Colo. 80302; NGDC File No. 00035.

2 The use of brand names in this report does not imply endorsement by the U.S. Geological Survey.
}

Two seismic-profiling systems were operated simultaneously and almost continuously over the entire track of the Kane. The principal system was the Seismic Section Profiler (SSP) built for the Geological Survey by the Marine Sciences Division of Teledyne Exploration. The acoustical source for this system is an electric discharge into the water. This discharge has as much as 160,000 joules of available electrical energy operating at about 15,000 volts. Discharging through four pairs of cables towed approximately $75 \mathrm{~m}$ behind the ship (fig. 3), the system was programed to fire every $6 \mathrm{sec}$ throughout the survey in order to maintain a uniform record scale. An exception to this firing rate was made on a single west-east line along the Texas-Louisiana outer shelf where a 4-sec firing rate was used.

Acoustic detectors for the SSP signals were 200foot (66-m) -long hydrostreamers consisting of 100 piezoelectric hydrophones. Generally, only one of these hydrostreamers was towed $114 \mathrm{~m}$ astern at a depth of about $6 \mathrm{~m}$; for parts of the survey, two were used to increase the signal-noise ratio and to provide better resolution of deep reflectors in the central gulf. The output of the hydrophones in each of these hydrostreamer arrays was summed through two preamplifiers (50 hydrophones per channel) located in a pod at the forward end of the array. Preamplification insures a low impedence input at low frequencies for onboard seismic amplifiers. Amplified signals were filtered to record the frequencies between 17 and $47 \mathrm{~Hz}$ on a modified Raytheon 196-B dry-paper recorder. An unfiltered $(16-250 \mathrm{~Hz})$ analog record was also obtained on magnetic tape.

Although the SSP yielded geologic information from depths as much as $4 \mathbf{- 5} \mathrm{km}$ below the sea floor, a separate high-resolution profiling system was necessary in order to detect reflectors in the uppermost $100 \mathrm{~m}$ of sediment. For this purpose, an EDOWestern model $240 \mathrm{~A}, 3.5-\mathrm{kHz}$ profiling system with a hull-mounted piezoelectric transducer was used. This system was fired once per second, and the results were shown on a Raytheon PFR 193C recorder. Resolution of less than $1 \mathrm{~m}$ was possible with this instrument, but because of the characteristics of its signal pulse length, it was not usable in water depths of less than about $50 \mathrm{~m}$.

\section{SEISMIC RECORDS}

The seismic profiles presented in this report are photographic reproductions of original field recordings on which no futher processing or enhancement has been attempted. In the interpretation of such records, a few helpful points should be kept in mind. 


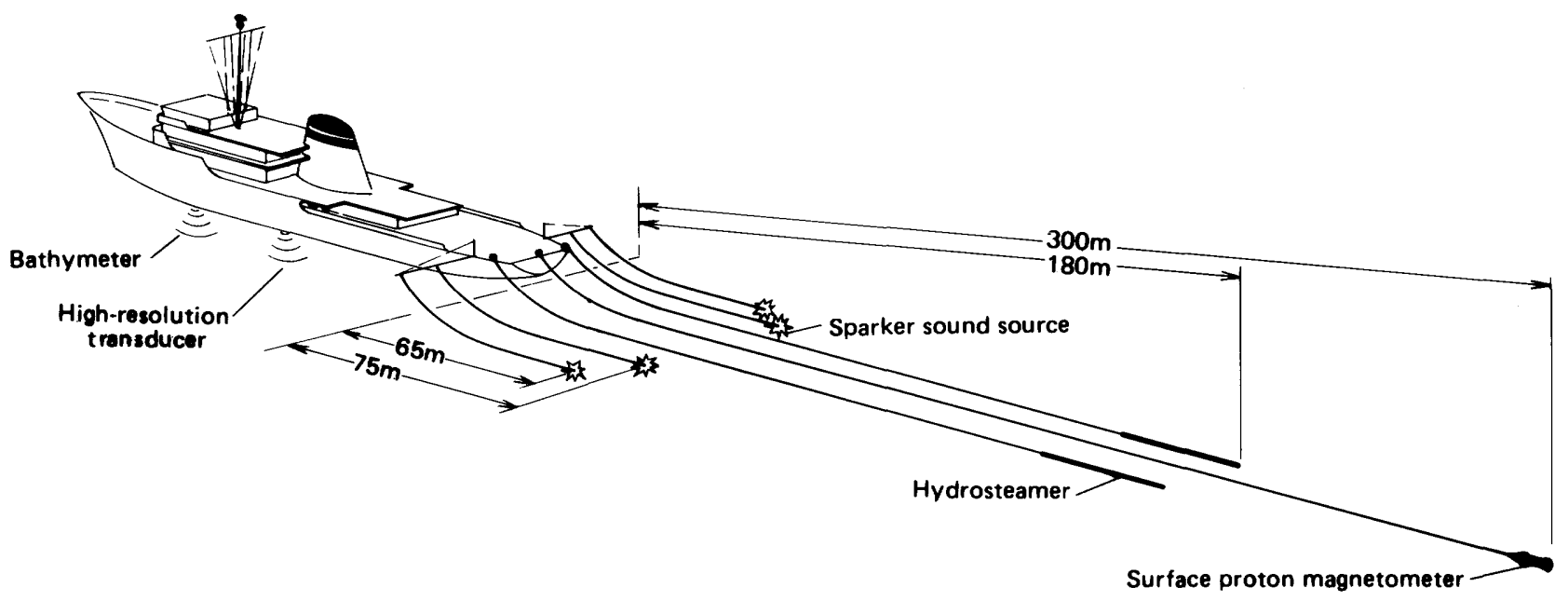

FIGURE 3.-Generalized diagram showing USNS Elisha Kane and relative towing position of equipment.

The technique of continuous seismic-reflection profiling at sea is based on the generation of a series of sound pulses in the water at precisely controlled and closely spaced intervals of time. The downward directed part of each of these pulses travels toward the sea floor and is partially reflected at boundaries between materials of differing acoustic impedance. Such boundaries occur at the sea bottom itself and at various subbottom layers across which physical properties of the sediments undergo changes. The acoustic energy reflected from these horizons returns to the sea surface, where it is detected by an array of hydrophones, converted to electrical energy, and transmitted through amplifiers and a band pass filter system to a graphic recorder.

The function of the graphic recorder is to transform the returning signals into a mode which can be interpreted as geological data. This is usually accomplished by using a moving stylus or a rotating helical contact blade to burn a mark on the recorder paper each time a sound pulse in the proper frequency range is detected. Because the contact point traverses the paper at a predetermined rate of speed, incoming signals are spaced out in a vertical relationship dependent upon the time of their arrival relative to shot time, the origin of the sound pulse which produced them.

The repetition of shot after shot as the ship moves over the bottom and the resulting alinement of burn marks side by side on the slowly moving recorder paper integrates the successive signals reflected from a given horizon into a line whose position on the record indicates the depth of the horizon below the sea surface. Signal returns from the various reflecting horizons below a ship moving along a sur- vey track are thus summed by the recorder in orderly fashion both vertically and horizontally into an approximation of a geologic cross section. However, a continuous seismic-reflection profile is only an approximate geologic cross section because (1) both vertical and horizontal scale are in units of time rather than distance, and (2) except for the sea-floor reflector, the geological identity of reflecting horizons is not inherent in the record.

Seismic-reflection profiles presented as illustrations commonly bear a vertical reference scale in units of time. Conversion to units of depth requires that velocities at which the sound waves traveled through the various media be known. Such information is not generally available, and depths assigned to various horizons in the accompanying captions are based on estimated velocities. The horizontal scale of a seismic-reflection profile is a function of the speed of the ship over the sea floor. The time function in this direction was supplied by marks placed on the record every 30 minutes. Translation to distance was made by plotting the ship's track and measuring the distance traveled during the particular time interval considered. In this report, both scales for the deeppenetration reflection profiles are given in units of time-seconds of traveltime for the vertical, and time (G.m.t.) of ship's position for the horizontal. The $3.5-\mathrm{kHz}$ high-resolution profiles illustrated herein are enlargements of small areas of the original record. The vertical scale of the high-resolution profiles is given in meters based on a water-column velocity of $1.5 \mathrm{~km} / \mathrm{sec}$; Greenwich mean time was used for the horizontal scale so the reader may make easy cross reference to the corresponding parts of deep-penetration profiles. 
Because of variations of sound velocity in sediment layers below the ship and variations in the ship's speed over the bottom caused by winds, currents, and other factors, vertical exaggeration in the profiles is not a constant. However, the differences from profile to profile within each system are small. An average vertical exaggeration of about $10: 1$ is a satisfactory approximation for the SSP profiles; 15:1, for the high-resolution profiles.

When the outgoing sound pulse is of sufficient strength and the sea-floor interface is highly reflective, echoing signals may return with sufficient energy to be reflected downward from the air-water interface so that a second round trip between surface and sea floor is accomplished. This appears on the record as a multiple of the sea-floor reflector at a depth equal to twice the actual water depth. The complexity of unprocessed seismic-reflection profiles is sometimes greatly increased by interference from second- and third-bounce multiples of the bottom reflector, of several subbottom reflectors, or by reflected signals that have travelled a variety of other bounce-path combinations between internal reflecting surfaces and the air-water interface. Such complicating events greatly increase the difficulty of record interpretation.

Ideally, all signals that are recorded as part of a seismic profile have been reflected from the sea floor directly beneath the survey vessel. In actual practice, side reflections often form an important part of the record. Side reflections are usually generated when a reflecting surface of greater elevation than normal sea bottom is encountered on one side of the ship's track. This could be a protruding bedrock peak or, on a finer scale, a boulder on an otherwise flat bottom. Such reflections are incorporated into the record at a time (depth) appropriate to their distance from the sound source and receiver; they may appear as hyperbolic curves below or somewhat above the sea-floor reflector.

The earliest signals in the sequence arriving at the hydrophone are those that have traveled a direct horizontal path from source to detector. These direct arrivals form a straight line on the record at a time following the shot time (time zero) which is proportional to the distance between source and detector. With recorder sweep rates of less than a second, the separation of time zero and the first arrival may be measurable, but in longer sweeps it may become negligible. In the records of this survey, the recorder printed a time-zero signal at the instant the shot was triggered. This appears as the first thin line at the top of the straight-line band of direct arrivals and is always counted as time (depth) zero.

Most recorders print the band of direct arrivals in proper sequence at the top of the page. If the arrival of the first bottom reflection then occurs at or near the end of the stylus sweep across the record, much of the subbottom information will be recorded at the beginning of the next sweep and will appear near the top of the page. Because a record of this nature is difficult to work with, many operators slow the stylus sweep in order to keep all incoming signals in their proper vertical order. This has the disadvantage of compressing the record vertically and possibly obscuring some of the otherwise available detail.

There are several mechanical solutions to this problem, but the one used in this survey was to regulate the timing of trigger pulse and stylus sweep so that the firing pulse could be produced in the middle or in the first or last quarter of the sweep. This had the advantage of maintaining the same vertical scale throughout the survey, while always keeping a maximum amount of subbottom data in the proper vertical sequence on the record. It had the disadvantage of allowing the straight-line band of direct arrival signals to pass through the center, lower quarter or upper quarter of the page, sometimes obscuring a narrow zone of data.

\section{ACKNOWLEDGMENTS}

As in all cases of scientific work at sea, a list of those responsible for the success of an operation would include scores of names of ship's crew, scientists, and technicians, and the host of others who lent their support ashore. Because it is not convenient to mention them individually, we would like to thank them collectively by expressing our appreciation to the U.S. Naval Oceanographic Office through Capt. T. K. Treadwell, U.S. Navy (retired), then commanding officer, whose personal interest and support made the survey possible; to the Kane's crew through her master, Capt. Jesse C. McCandless, MSTS; to the scientific crew through chief scientists Robert H. Feden and Herbert C. Eppert, Jr., of the U.S. Naval Oceanographic Office, and through David W. Scholl, who took a turn aboard as U.S. Geological Survey party chief. Finally, a special word of thanks is due Carl Berglund and the Marine Sciences Division of Teledyne Exploration whose cooperation and assistance are greatly appreciated.

We also wish to express our thanks to R. N. Bergantino of the U.S. Naval Oceanographic Office whose sketch of the USNS Kane appears on the cover. 


\section{GEOLOGY OF THE GULF OF MEXICO}

\section{GEOLOGIC HISTORY}

Although recently developed hypotheses of seafloor spreading and crustal-plate tectonics are yielding startling insights into the origins of the earth's major ocean basins, the origin and pre-Mesozoic history of the Gulf of Mexico are still largely matters for conjecture. Briefly stated, the principal hypotheses of the origin of the gulf are (1) that the gulf basin was once a landmass, the Llanoria of Miser (1921), which foundered along boundary faults bordering the present coastal plain from south-central Texas to Mobile Bay and the Florida and Yucatan platforms (Schuchert, 1935; Weaver, 1950 ; Eardley, 1954); (2) that the gulf was formed during late Triassic-Jurassic time when North America was rifted away from the African and South American continents (Yarborough, 1968; Ball and Harrison, 1969; Freeland and Dietz, 1971) ; and (3) that the gulf is an original ocean basin whose crust and mantle have been depressed below normal levels in response to the loading of an abnormal thickness of sediments (Ewing and others, 1960, 1962). Whatever the origin of the gulf, the general consensus of those who have weighed the evidence is that the basin is relatively old and that its morphology has evolved through a combination of intrabasin tectonic and sedimentary processes. Unlike the Caribbean basins whose margins have been either created or highly modified by plate-tectonic processes, the gulf, in the light of present evidence, appears to have drifted passively westward with the North American continent, being essentially undisturbed by the Mesozoic-Cenozoic cycle of sea-floor spreading (Antoine and Pyle, 1970).

Little is known about the pre-Mesozoic history of the area of the present gulf basin. Meyerhoff (1967) has hypothesized that the basin was present as early as the end of the Precambrian. More important is the circumgulf stratigraphic evidence (Meyerhoff, 1967; Wilhelm and Ewing, 1972), which suggests that marine conditions existed in the gulf region as early as Pennsylvanian-Permian time. Our best knowledge of gulf history spans only the interval since the Jurassic, a brief summary of which follows.

By Early Jurassic time, evaporite deposits, chiefly salt, were being precipitated in shallow basins around much of the gulf margin (Murray, 1966; Halbouty, 1967; Kirkland and Gerhard, 1971). This period of evaporite accumulation continued until late Middle or possibly Late Jurassic, during which time great thicknesses of salt were laid down. The conditions of formation of these deposits have not been established, nor, for that matter, have the precise boundaries of salt basins or their contiguity.

By Early Cretaceous (Aptian-Albian) time, organic reefs, flourishing in the southern gulf region, were outlining the areas of the present peninsular masses of Florida and Yucatan. There is evidence that these early reefs extended as an essentially continuous chain around the entire gulf, reaching northward across Louisiana and Texas as the WashitaFredericksburg reef trend (Antoine and others, 1967) and extending southward through eastern Mexico, near Tampico, in part as the El Abra reef and the Golden Lane atoll (Uchupi and Emery, 1968).

No conclusive evidence as to the nature of the central basin in Early Cretaceous time is yet available. Recent deep-sea drilling into the sediments in the southern part of this basin however, indicates that deep-water conditions existed there at least as early as Late Cretaceous (Santonian) time, and in the extreme southeast since Cenomanian time (Worzel and Bryant, 1970).

At the close of the Mesozoic, great changes took place in the character of the northern gulf. The subsidence of the Gulf Coast geosyncline and a concurrent increase in sedimentation rates created a vast wedge of clastic sediments which overwhelmed the Cretaceous reefs in Texas and Louisiana and began to fill the northern gulf. The coastal plain in that region prograded steadily southward into the basin during Tertiary time. Superimposed on this southeastward-growing wedge of terrigenous clastic material was a northeasterly shift of major depositional sites, as source areas migrated from the ancestral Rio Grande and Nueces River watersheds in Eocene time to those of the Mississippi River in Miocene time and later (Hardin, 1962, p. 8).

While voluminous sedimentation altered the northern sector of the gulf, the southeastern margin remained relatively unchanged. In the warm clear waters around the peninsulas of Florida and Yucatan, carbonate-secreting organisms grew in abundance. Although these southeastern areas also subsided steadily throughout the Tertiary Period, accumulation kept pace with sinking, and shallow-water carbonate deposits became very thick.

The continental margin in the Gulf of Mexico has thus developed into two separate geological provinces-an eastern and southern region of shallow carbonate banks, probably not greatly different from its Mesozoic ancestor, and a western region of ter- 
rigenous sediments built out into the gulf wholly during Cenozoic time.

\section{CONTINENTAL MARGIN, NORTHWESTERN GULF OF MEXICO}

TEXAS-LOUISIANA SHELF

The continental shelf in the northwestern Gulf of Mexico ranges in width from about $100 \mathrm{~km}$ off the Rio Grande in Texas to more than $200 \mathrm{~km}$ south of the Texas-Louisiana boundary (fig. 1). Farther east, it is again narrowed by the bulge of the Mississippi River Delta, whose presently active lobe almost entirely crosses the shelf southeast of New Orleans to empty directly onto the continental slope. The break in slope that marks the outer edge of the shelf is difficult to define throughout much of this region, but on the average it is at a depth of about $120 \mathrm{~m}$ (Curray, 1960). The surface of the shelf is generally smooth but is marked here and there by subdued topographic features such as stream channels and shorelines relict from times of glacially lowered sea level, as well as by low fault scarps and banks associated with salt structures (Ballard and Uchupi, 1970).

The principal influence on the structural character of the northwestern gulf shelf is the presence of vast amounts of salt in the sedimentary sequence, which lends a high degree of tectonic mobility to an otherwise relatively stable area. Deep-seated salt pillows have arched the Tertiary formations which otherwise have a gentle southward dip; tall slender columns of salt have pierced the Tertiary beds; and evaporitic material has migrated laterally and displaced and rearranged the thick clastic deposits by processes of faulting, slumping, and local thickening or thinning of beds.

The very large body of literature on salt and salt structures in the gulf region has been reviewed by Murray (1966) and Halbouty (1967). Halbouty reported that salt had been penetrated in 340 domal structures in the northwestern Gulf Coastal Plain. Lehner (1969) reported that in 10 out of 12 diapiric structures drilled on the continental slope in the northern gulf, salt was penetrated at depths of less than 1,000 feet $(305 \mathrm{~m})$ below the sediment surface.

In addition to structures known to be underlain by salt, a great number of diapiric forms have been located by geophysical means, and it is generally assumed that, with few exceptions, they, too, are salt structures. However, diapirs of shale origin are known in this region (Murray, 1968). Figure 4 summarizes the location of diapiric structures and known salt domes reported to date or shown by the Kane profiles.

Banks along the outer edge of the shelf mark the crests of shallow salt domes (Moore and Curray, 1963; Uchupi and Emery, 1968; Lehner, 1969), although such structures rarely penetrate the shallow sea floor of the shelf proper. Their presence is marked in the subbottom by an arching of beds and by a clustering of nearly vertical small-displacement faults above their deeply buried crests (figs. 8, 9). Over shallower diapirs, older beds are pushed upward and exposed to erosion on the sea floor, but in the unconsolidated sediments of the gulf shelf, the resulting topography would be slight and quickly erased (figs. 10, 15A).

Salt structures in the northern Gulf Coastal Plain are believed to be restricted to the area basinward from the inner system of coastal-plain faults (fig. 4) which extends from the western tip of Florida almost to the Rio Grande (Murray, 1961, p. 99, fig. 3.10). The apparent basinward limit of salt is the Sigsbee Escarpment at the base of the continental slope, although some geologists believe that salt is continuous beneath the deeper parts of the western gulf as well (Ewing and others, 1962).

Strike-fault systems of regional extent are an important factor in the geology of the northern Gulf Coastal Plain. In such systems, faulting is normal and down-to-basin, fault-plane dips being $35^{\circ}-70^{\circ}$, generally steeper nearer the surface and flattening basinward with depth. Most faults of this type show evidence of movement contemporaneous with sediment deposition and are termed "growth faults" (Ocamb, 1961; Hardin and Hardin, 1961). They are identifiable in the seismic sections by an increase in the thickness of beds on the downthrown block with respect to equivalent beds on the upthrown block, and a consequent increase of displacement with depth. Active growth faults are present on the continental shelf and appear in abundance in most seismic-reflection surveys. However, geophysical data on the continental shelf are not yet available in sufficient quantities to permit correlation of fault crossings into mappable regional trends.

\section{TEXAS-LOUISIANA SLOPE}

The dimensions of the continental slope off Texas and Louisiana are about the same as those of the adjacent shelf (fig. 1). The greatest slope width is about $240 \mathrm{~km}$ at a point south of eastern Louisiana, and its least width of $110 \mathrm{~km}$ is seaward of the Rio Grande. The average gradient of this vast area, according to Shepard (1963), is slightly less than $1^{\circ}$. 
In early studies of the bathymetry of the slope, it was found by Gealy $(1955$, p. 204) to have "a varied topography of high relief which does not resemble the topography of the continental slope of either the Atlantic or Pacific coast ..." and was aptly described as "hummocky." The origin of this hummocky topography was largely a matter for speculation until continuous seismic-reflection profiling revealed the extensive influence of intrusive structures (Moore and Curray, 1963). Although little doubt existed thereafter that these slope structures were an extension of the Gulf Coast salt basin, the presence of salt beneath the continental slope was not definitely established until salt was penetrated by drilling in structures on the upper slope (Lehner, 1969). Salt structures on the slope occur in a great variety of sizes and shapes, ranging from slender, rodlike forms which have pierced thousands of meters of sediment to reach the surface, to elongate ridges which arch the overlying sediment into broad anticlines.

Although patterns or trend are not apparent in

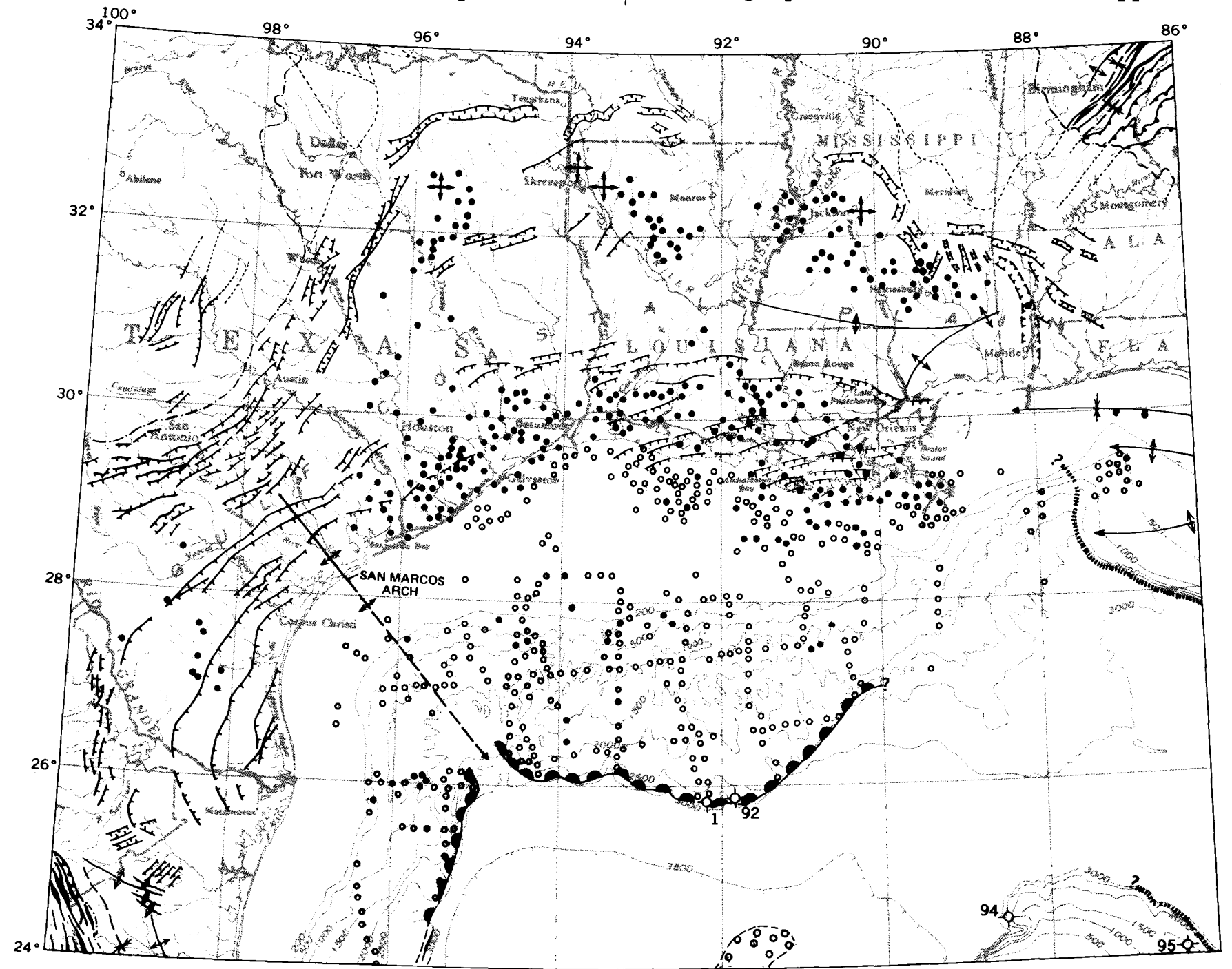

\begin{tabular}{|c|c|c|c|}
\hline 100 & & 100 & 200 MILES \\
\hline 100 & 0 & 100 & 200 KILOMETERS \\
\hline
\end{tabular}

FIGURE 4.-Tectonic sketch map showing major structural trends and features and JOIDES core sites in northwestern Gulf of Mexico and adjacent coastal plain of the United States and Mexico.

Onshore information primarily from King (1969), supplemented by data from Applin and Applin (1965),
Franco (1970a, b), Halbouty (1967), Murray (1961), and Sanchez M. and Lopez R. (1968).

Offshore information principally from Kane profiles; additional data from Bryant, Antoine, Ewing, and Jones (1968), Bryant and others (1969), Ewing and Antoine (1966), Ewing and others (1969), Halbouty (1967), 
the distribution of known domes on the continental slope (fig. 4), the basic division of slope topography made in earlier studies has been supported by more recent work. Modern seismic-reflection profiles show the hummocky upper-slope topography to be formed by the thinly covered crests of isolated diapiric structures. In contrast to the shelf, where piercement structures tend to be slender, rodlike, and more widely separated, diapirs in the upper slope seem to consist of ridgelike masses having thick spines which thrust upward a kilometer or more

\section{EXPLANATION}

\begin{tabular}{|c|c|}
\hline 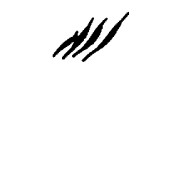 & $\begin{array}{l}\text { ANTICLINES - Elongate, closely spaced, and mainly } \\
\text { involving only sediments and sedimentary rocks in } \\
\text { Mexico and western Gulf; metamorphic rocks in } \\
\text { Yucatan Channel. Submerged areas are diagram- } \\
\text { matic in part }\end{array}$ \\
\hline$\stackrel{t \rightarrow}{\longrightarrow}$ & $\begin{array}{l}\text { ANTICLINAL AXIS - Axis of open fold or arch showing } \\
\text { direction of plunge; mainly involving basement rocks, } \\
\text { dashed where inferred }\end{array}$ \\
\hline & $\begin{array}{l}\text { SYNCLINAL AXIS - Axis of large fold or embayment } \\
\text { showing direction of plunge; many of these involve } \\
\text { basement rocks; dashed where inferred }\end{array}$ \\
\hline+ & DOME \\
\hline . & THRUST FAULT - Sawteeth on overth \\
\hline كــــ & $\begin{array}{l}\text { NORMAL FAULT - Hachures on downthrown side } \\
\text { CONCEALED FAULT - Involves basement surface only }\end{array}$ \\
\hline 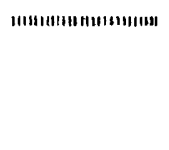 & $\begin{array}{l}\text { BARRIER REEF - Approximate trend of Lower Cre- } \\
\text { taceous reef revealed by seismic-reflection profiles } \\
\text { and bottom samples in eastern Gulf of Mexico, and } \\
\text { by geophysical data and drilling in Mexico }\end{array}$ \\
\hline - $\circ$ & $\begin{array}{l}\text { SALT DOMES - Diapiric structures known or inferred } \\
\text { to be formed by evaporites. Dot indicates domes in } \\
\text { which salt or caprock has been reached by drilling; } \\
\text { open circle denotes diapirs revealed by seismic- } \\
\text { reflection profiling. The apparent linear distribution } \\
\text { in places reflects the ship's track }\end{array}$ \\
\hline & $\begin{array}{l}\text { SALT FRONT - Leading edge of salt mass where lateral } \\
\text { as well as upward movement is inferred. Humps on } \\
\text { evaporite side }\end{array}$ \\
\hline $1-\phi-$ & $\begin{array}{l}\text { DRILL HOLE - Location and number of JOIDES Deep } \\
\text { Sea Drilling Project site }\end{array}$ \\
\hline.--1 & INNER MARGIN OF COASTAL PLAIN \\
\hline----1 & $\begin{array}{l}\text { ROVINCE - Mappable boundary } \\
\text { as shown by seismic reflection } \\
\text { Plain }\end{array}$ \\
\hline $\begin{array}{l}\text { Harbison } \\
(1970), \\
\text { lin and } \\
(1969) \\
(1971),\end{array}$ & $\begin{array}{l}\text { (1968), Lehner (1969), Malloy and Hurley } \\
\text { Martin (1972), Moore and others (1971), Now- } \\
\text { others (1965), Oglesby (1965), Pyle and others } \\
\text { Uchupi and Emery (1968), Vedder and others } \\
\text { Worzel and others (1968), and Worzel and Bryant }\end{array}$ \\
\hline
\end{tabular}

above the main structure (pl. 1, $A-A^{\prime}$; fig. 11). In areas between ridges, slightly disturbed bedded sediment is present to depths of at least $3-4 \mathrm{~km}$, although crests of adjacent salt structures may be covered by only 200-300 m of sediment. Small depressions on the crests of salt structures and basins between salt spines are usually filled or partially filled with flat-lying beds possibly derived from sediment shed off the tops of adjacent peaks.

The lower slope, on the other hand, is a region about 50-75 $\mathrm{km}$ wide that has smoother topography; it separates the upper slope from the Sigsbee Escarpment (pl. 1, $A-A^{\prime}$ ). In contrast to the upper slope which is underlain by salt stocks and massifs, the lower slope appears to be underlain by a single ridge of salt at least $500 \mathrm{~km}$ long. The top of the seaward face of this salt wall forms the Sigsbee Escarpment (Lehner, 1969). The surface of the salt mass is thinly covered by sediment. Lacking are the tall spines which create the rugged relief on the upper slope. Instead, the upper surface of the lowerslope salt mass is uneven, consisting of pillows and shallow depressions.

Ewing and Antoine (1966) conceived the northern gulf margin as having evolved under the control of a salt-flow process, whereby the accumulation of sediment updip creates a horizontal pressure gradient, as suggested by Bornhauser (1958), which causes the underlying salt to migrate seaward. The front of the mobile salt layer is thought to form a ridge behind which subsequent sedimentary deposits accumulate and induce the growth of additional ridges, each just seaward of the previous one. The Sigsbee Escarpment is the present frontal ridge. This theory finds support in the seismic-reflection studies by Amery (1969) who distinguished a layer of salt extruded southward for a distance of $10 \mathrm{~km}$ over flat-lying beds in front of the Sigsbee Escarpment. Because of the lack of diapiric structures in the continental rise south of the Sigsbee Escarpment, Antoine and Bryant (1969) concluded that the Sigsbee salt front is the southern limit of salt in the Gulf Coast geosyncline. This was also suggested by deJong (1968) whose seismic studies indicate that the salt beneath the continental slope thins rapidly toward its toe at the Sigsbee Escarpment and overlies a thick sequence of undisturbed strata of lower velocity which is probably truncated against the base of the salt.

Evidence of lobation of the Sigsbee salt front comes from a Kane seismic profile taken parallel to the escarpment (fig. 12, $C-C^{\prime}$ ). The profile reveals a reentrant in the salt front at least $25 \mathrm{~km}$ wide at 
that point, flanked by massive salt on either side. The first drill site for the JOIDES (Joint Oceanographic Institutions Deep Earth Sampling) Deep Sea Drilling Project was in this reentrant and penetrated $619 \mathrm{~m}$ of fine-grained terrigenous sediment, all Pleistocene in age (Ewing and others, 1969). This indication of the undulating shape of the salt front agrees well with Amery's (1969) suggestion of seaward growth by the extrusion of tongues of salt.

Upward growth of the salt front is indicated by a block of bedded sediment perched atop the western salt lobe (fig. $12, C-C^{\prime}$; fig. 13). The regularity of bedding within this exotic block suggests that it may originally have been deposited as part of the lower sequence of continental-rise sediments, but was elevated to its present position by rising salt.

It has been generally assumed that the Sigsbee Escarpment makes a sharp bend southward at about long $94^{\circ} 30^{\prime} \mathrm{W}$., in conformity with the change in trend of the continental slope in the northwest corner of the gulf (Gealy, 1955; Bryant, Antoine, Ewing, and Jones, 1968). More recent evidence, however, indicates that a break occurs in the continuity of the salt front in that region and that the scarplike feature which extends southward from lat $26^{\circ} \mathrm{N}$. is the front of a separate salt mass (fig. 11, $B-B^{\prime}$; fig. 14) related to the Rio Grande basin (Garrison and Berryhill, 1970). This suggests that the salt masses from the Gulf Coast salt basin and the Rio Grande salt basin have acted independently to produce two salt fronts separated by a reentrant in the continental slope near their junction (fig. 4). The structure of the lower slope in the area between the two salt fronts is anomalous with respect to that of the adjacent regions because of the scarcity of salt domes. The Kane profiles show a near-horizontal undulating basement surface about $3 \mathrm{~km}$ below sea level, which is interpreted to be the top of a salt layer. About $1 \mathrm{~km}$ of undisturbed sediment overlies the salt.

The absence of diapiric structures in this restricted area suggests that the salt connection between the Gulf Coast and Rio Grande salt basins thins drastically beneath the lower slope. Although salt domes do occur to the northwest on the upper slope, they tend to be widely scattered and less massive than those on the adjacent slope regions.

The distribution of salt structures in the northwest corner of the gulf is, in fact, analogous to that in the adjacent coastal plain of southern Texas, where the San Marcos arch, striking normal to the coast, may have been a structural divide between the
Gulf Coast and Rio Grande salt basins (fig. 4). The region over the crest of the structure has no salt domes, and salt is apparently thin or absent (Halbouty, 1967, p. 22). Similar conditions downdip on the continental slope suggest the possibility that the influence of the San Marcos arch continues seaward to affect the continental margin (Garrison and Berryhill, 1970).

\section{CONTINENTAL MARGIN, EASTERN MEXICO}

\section{EAST MEXICO SHELF}

The continental margin off eastern Mexico is the narrowest in the entire gulf (fig. 1). The coastal plain is constricted by the Sierra Madre Oriental, whose southeasterly strike converges with that of the coast. The edge of the shelf at a depth of about $200 \mathrm{~m}$ is less than $40 \mathrm{~km}$ offshore near Tampico (fig. 1) as compared with more than $200 \mathrm{~km}$ off Texas and Louisiana, but the shelf again widens eastward to about $130 \mathrm{~km}$ in Golfo de Campeche near Carmen. Relief on the shelf surface is low and generally formed by small fault scarps in the north or by reefs in the south. North of Tampico, some of the surface relief is attributable to salt intrusions, but terracelike features related to Pleistocene low sea levels have been reported on the shelf in the Golfo de Campeche (Uchupi, 1967).

The structure of the Mexican shelf is affected by elements that, although not always expressed topographically, lend a unique character to this part of the gulf continental margin. The northern part of the shelf and upper slope, almost as far south as Tampico, belongs to the Texas-Louisiana salt-dome province or, more properly, to the Rio Grande salt basin. The Rio Grande salt front strikes southwest toward Tampico and disappears beneath shelf deposits that thicken eastward off the flank of the Tamaulipas arch (fig. 5). Behind the salt front, diapiric structures and a thick sedimentary section lend the shelf its character.

From about $50 \mathrm{~km}$ north of Tampico southward to the volcanic terrane north of Veracruz, the shelf is within the Tampico structural embayment (Murray, 1961, p. 139). Structural features along this part of the coast appear related to basement highs which have created anticlinal structures in the overlying sediments (Franco, 1970a), or upon which Cretaceous reefs such as the Golden Lane atoll have formed.

South and east of Veracruz, coastal-plain and continental-shelf sediments were deposited in the Isthmian structural embayment which extends 

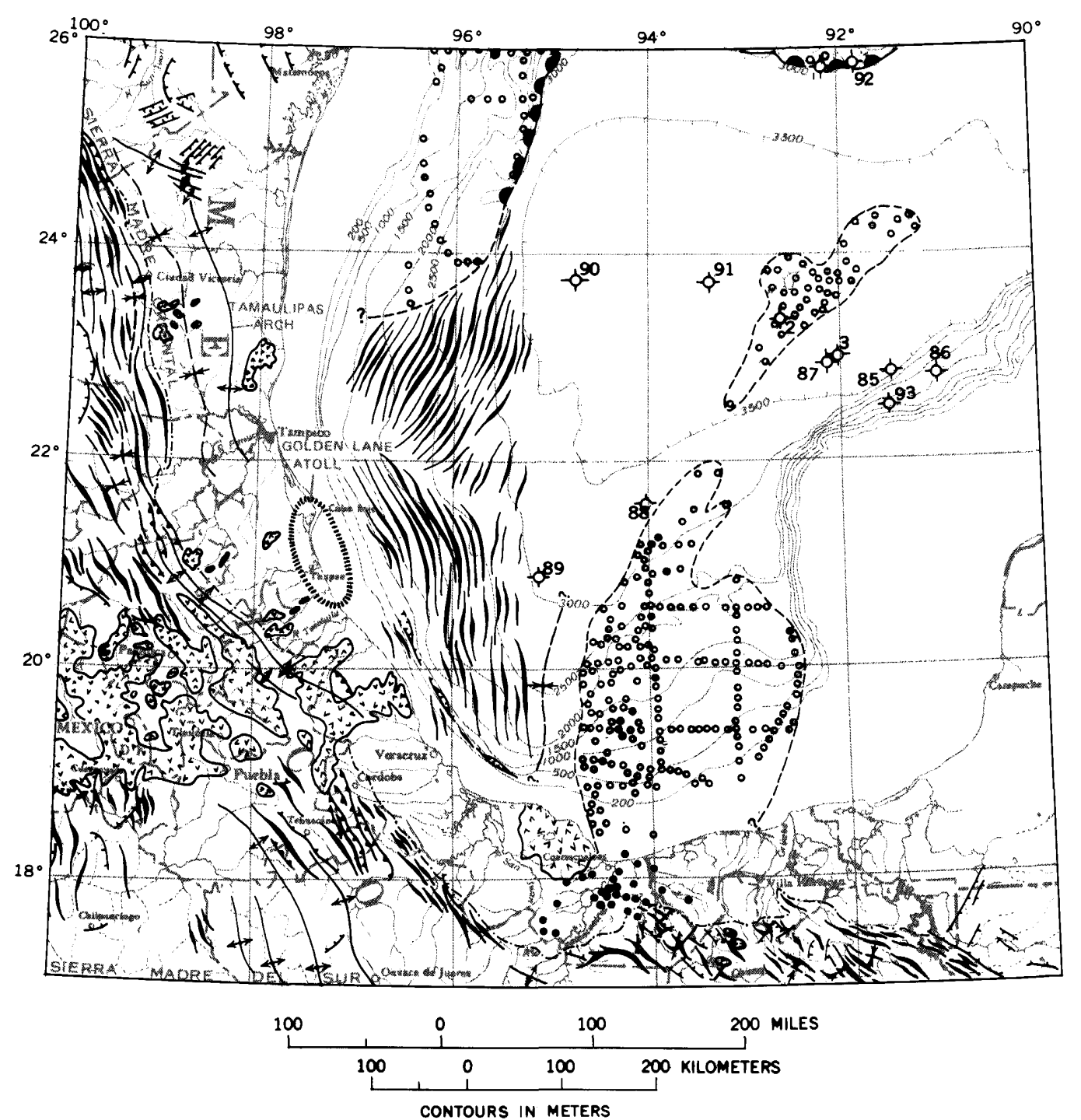

\section{EXPLANATION}

ANTICLINES - Elongate, closely spaced, and mainly involving only sediments and sedimentary rocks in Mexico and western Gulf; metamorphic rocks in Yucatan Channel. Submerged areas are diagrammatic in part

ANTICLINAL AXIS - Axis of open fold or arch; mainly basement rocks

SYNCLINAL AXIS - Axis of large fold or embayment; many of these involve basement rocks.

dashed where inferred

\section{THRUST FAULT - Sawteeth on overthrust side}

NORMAL FAULT - Hachures on downthrown side

BARRIER REEF - Approximate trend of Lower Cre taceous reef revealed by seismic-reflection profiles and bottom samples in eastern Gulf of Mexico, and by geophysical data and drilling in Mexico

- $\quad$ SALT DOMES - Diapiric structures known or inferred to be formed by evaporites. Dot indicates domes in which salt or caprock has been reached by drilling; open circle denotes diapirs revealed by seismicreflection profiling. The apparent linear distribution in places reflects the ship's track

SALT FRONT - Leading edge of salt mass where lateral as well as upward movement is inferred. Humps on evaporite side

EDGE OF DIAPIRIC PROVINCE - Mappable boundary of diapiric structures, as shown by seismic reflection profiles in the Golfo de Campeche and Sigsbee Plain

CONTINENTAL VOLCANIC ROCKS - Mainly Quaternary, but include some Oligocene to Pliocene in the Trans-Mexican Volcanic Belt

92. DRILL HOLE - Location and number of JOIDES Deep Sea Drilling Project site

- - - - INNER MARGIN OF COASTAL PLAIN

FigURE 5.-Tectonic sketch map of southwestern Gulf of Mexico showing major structural trends and features and JOIDES core sites in gulf basin and adjacent regions of Mexico. Sources of information given in figure 4. 
through the State of Tabasco into the State of Campeche (fig. 5). Part of the shelf in the center of this area has been elevated since late Tertiary time by activity associated with the volcanic Tuxtla uplift, which tilted layers of shelf sediments that were later truncated and covered by a few meters of Quaternary deposits (fig. 18, $A-A^{\prime}$ ).

Eastward from the Tuxtla region, shelf structure is influenced by salt diapirs of the Tabasco-Campeche (Isthmian) salt basin. In nearly all respects analogous to the salt basins of the northern gulf, the domes of this region create a shelf profile strikingly like that of Texas and Louisiana (figs. 17, 18). In the coastal plain to the south, these anticlinal salt structures are responsible for important accumulations of oil and gas. Beneath the slope and abyssal plain to the north, they extend to the Sigsbee Knolls of the central gulf basin (Worzel and others, 1968).

\section{MEXICAN SLOPE}

In contrast to the lack of relief on the shelf, the continental slope off eastern Mexico from the Rio Grande to Banco de Campeche offers a spectacular variety of topographic features. Formed by tectonic processes of regional extent, these features are segregated into three broad structural provinces (fig. 5). In the north, the salt diapirs along the Texas slope extend southward off Mexico in a continuation of the continental-slope structures of the northwest gulf. A somewhat similar province of salt structures forms the continental slope in eastern Golfo de Campeche, extending from the State of Tabasco to the northwest tip of Banco de Campeche. Between these two provinces of salt-growth structures are the Mexican Ridges.

The Mexican Ridges, first described by Bryant, Antoine, and Ewing (1968), are a series of linear anticlinal folds whose trends are essentially parallel to the slope (pl. 1). Individual ridges are continuous over great distances and have relief as great as $500 \mathrm{~m}$. They form a strikingly regular regional pattern with a wavelength averaging $10-12 \mathrm{~km}$ and extend almost $400 \mathrm{~km}$ along the Mexican slope from lat $24^{\circ} \mathrm{N}$. to Veracruz where they pass beneath upper slope deposits and are no longer distinguishable by seismic profiling. Near lat $22^{\circ} \mathrm{N}$., the fold system is interrupted by a low area in which folds, although present, are of much lower amplitude (fig. $\left.19, B-B^{\prime}\right)$. The apparently abrupt termination of normal high-amplitude fold ridges across this gap has led to speculation that a major fault zone crosses the slope at this point (Bryant, Antoine, Ewing, and Jones, 1968).
In an upslope direction, troughs of the ridge system are progressively filled by flat-lying deposits until the ridges are buried. Although seismic profiles show folding to persist landward for a short distance beneath upper-slope deposits, extent of the folds in that direction is not known. Downslope, the intensity of folding changes abruptly from tight steep structures to a few gentle undulations which mark the transition to undisturbed beds of the abyssal plain.

The origin of the folds on the Mexican slope is mostly a matter of conjecture. Jones, Antoine, and Bryant (1967) suggested that they are related to an underlying layer of salt whose initial deformation under sediment loading created a series of salt anticlines. Through subsequent increase in the sediment overburden and the upward growth of secondary salt structures, the fold ridges on the modern slope have evolved as anticlinal ridges. Indirect evidence of this process is offered by the mathematical models of Selig and Wermund (1966) which predict that under certain conditions of loading, salt will flow into parallel ridges whose spacing is comparable to that of the Mexican Ridges.

Gravity data over the Mexican Ridges from USGS-IDOE (U.S. Geological Survey-International Decade of Ocean Exploration) leg 1 (G. W. Moore, written commun., 1972) indicate a correlation between negative Bouguer anomalies (3-10 mgal) and the positions of certain ridge crests; this correlation suggests that at least some of the ridges have cores of low-density material, possibly salt or shale.

If salt is present beneath the fold system, according to Bryant, Antoine, Ewing, and Jones (1968), the ridges off the eastern Mexican coast might be continuous with the more complex structures of the Texas-Louisiana slope and, according to Antoine and Bryant (1969, p. 2547), could be "a natural model representing one 'end member' of a series of stages of development whose other 'end member' is the continental slope of Texas and Louisiana." Although the hypothesis is plausible, the evidence for a salt layer is sketchy. Alternative hypotheses suggested by Bryant, Antoine, Ewing, and Jones (1968) are: (1) Folding caused by compressional tectonic stresses, (2) folding related to faulting, and (3) gravity sliding of sedimentary rocks on a décollement surface.

Gravity sliding is a possible alternative to the salt deformation theory, especially after examination of the Kane data. Seismic-reflection records, such as those in figure 19 and on plate 1 of this report, show at least $3 \mathrm{~km}$ of bedded sediment to be involved in 
the folding with no indication of a salt basement to that depth. On many ridges, the form of the fold is repeated internally by each individual reflector with no indication that the fold is dying out upward, as would be the case were the beds folded over the crest of a rising diapir or draped over a buried anticline. Rather, the thinning of beds on the flanks of folds and their relative thickening over crests indicates considerable plastic movement of the folded sediments themselves. The degree of internal reflection decreases with the intensity of folding so that some folds contain only a few steeply dipping reflectors and some have none at all. It might be assumed that the reflectorless anticlines are piercement structures with salt cores, but from the data at hand, it is apparent that either in many such cases beds are so sharply tilted that they inhibit the reflection of acoustic signals or the interior of the fold has been so tightly compressed that bedding was destroyed.

Downslope movement of so thick a section of previously stable deposits would have been in response to steepening of the seaward slope of the basement. The form of the resulting folds in the sedimentary cover suggests that sliding of the sedimentary beds has been sporadic. If all the folds had formed in one movement, compressive forces would have been greatest at the bottom of the slope, and folds created there would be tightest. The Kane records, however, show an abrupt change from very tight folds to broad gentle undulations at the lower limit of folding. The gentle undulations are interpreted as a young set of folds affecting the previously undisturbed area as a result of renewed downslope movement. Presumably they, in turn, will be further compressed by future movement which will advance the fold ridges farther basinward.

The impression of large-scale submarine landsliding is heightened by the grouping of the fold ridges in two lobate areas whose general trend is consistent within each lobe but differs between lobes (fig. 5). Although convex downslope in both bases, ridges in the north lobe trend generally northeast, whereas those in the south lobe trend northwest, roughly parallel to the coast (Bryant, Antoine, Ewing and Jones, 1968; Bergantino, 1971). Between the lobes is a region of low undulatory folds, centered on lat $22^{\circ}$ N., whose wavelengths seem comparable to those of the main folds, but whose amplitudes and intensity of folding are far less. This region has clearly not been subjected to the degree of stress of the adjacent ridged areas and appears to have been little involved in the sliding. It opens fanlike toward the basin, conforming to the lobate shapes of the areas to north and south. In the shoreward part of this interlobe region, the gentle wavelike forms of the folds may represent the plunging ends of adjacent anticlines, whereas seaward they may be young folds resulting from renewed sliding. North-south seismic profiles that cross this zone show an abrupt change in style of folding but also show a continuity of beds from one style to the other that precludes faulting as a cause of the scarps noted by earlier investigators (Bryant, Antoine, and Ewing, 1968; Bryant, Antoine, Ewing, and Jones, 1968).

If the Mexican Ridges have been formed by largescale gravity sliding, the décollement surface itself has not yet been defined. It may be a layer of the low-density material whose presence was indicated in the cores of some ridges by G. W. Moore's (written commun., 1972) gravity data. This material could be interpreted as salt or shale.

\section{CAMPECHE KNOLLS}

The continental slope in the eastern part of the Golfo de Campeche is a province of diapirs strikingly similar in structural form to the slope off Texas and Louisiana (fig. 5). The slope diapirs are essentially continuous southward into the States of Tabasco and Campeche (Ballard and Feden, 1970), where salt has been drilled in similar structures in the Isthmian salt basin (Murray, 1961, p. 154). Northward, the slope diapirs continue toward the Sigsbee Knolls (Worzel and others, 1968), where caprock typical of salt domes was drilled by JOIDES (Burk and others, 1969). It is, therefore, generally assumed that salt underlies the entire continental slope region and is essentially continuous from the Isthmian salt basin to the Sigsbee Knolls.

The Campeche Knolls are bordered on the east by the carbonate Banco de Campeche with its steep escarpment, from which the knolls are separated by Campeche Canyon (fig. 1) (Creager, 1958). Although not a canyon in the erosional sense, this intervening belt of undisturbed sediment gains that appearance from the canyon-wall form of its steep bounding slopes of limestone on the east and diapirically elevated sediments on the west. (See pl. 1, $D-D^{\prime}, E-E^{\prime}$, $F-F^{\prime}$.) To the west, the knolls are bordered by a narrow tongue of flat-lying abyssal sediments, an extension of the Sigsbee Plain, which separates the western limits of the Campeche Knolls from the eastern edge of the Mexican Ridges.

An examination of the various structural forms shown in the Kane records suggests that the distribution of structures in this province of diapirs offers 
clues to the origin and history of the underlying salt (fig. 6). In the central region of the upper slope near lat $20^{\circ} \mathrm{N}$, an area of more than $20,000 \mathrm{~km}^{2}$ is underlain by salt massifs. The top of the salt mass in

this region is thrust upward into a multitude of peaks and spires, generally covered by about $1 \mathrm{~km}$ of strongly faulted and folded sedimentary beds. Because of the vertical displacement of these for-

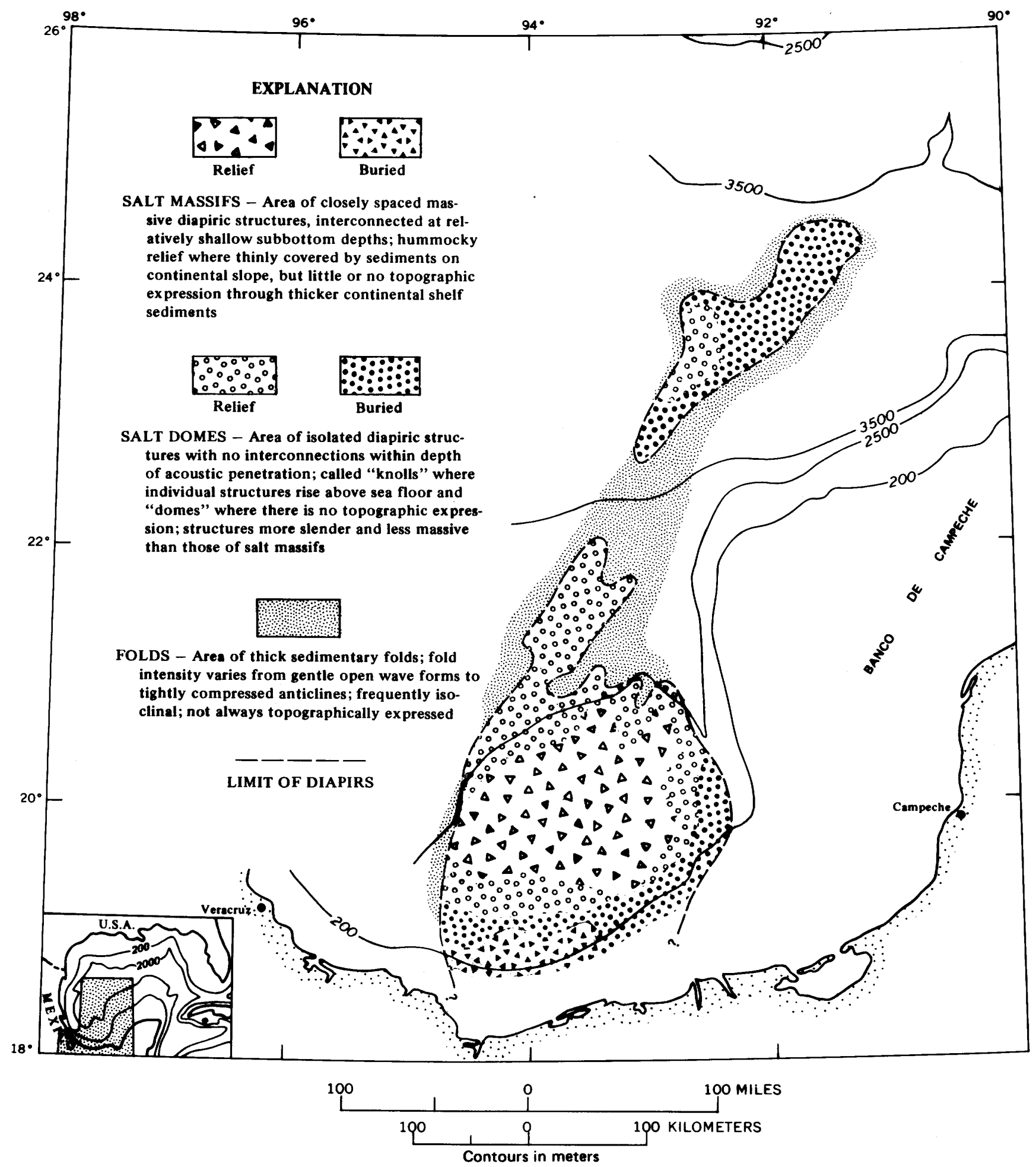

FIGURE 6.-Generalized map showing distribution and morphological classification of diapiric bodies and related features in Golfo de Campeche and Sigsbee Knolls region, Gulf of Mexico. 
merly horizontal sediments, the sea floor is hummocky, much like the topography of the continental slope in the northwest gulf. Because probable top-ofsalt reflectors can be carried at shallow depths on all seismic lines crossing the area, the central region is probably the crest of a single salt mass.

Surrounding the region of massive salt is a rather narrow belt of isolated salt domes, which in most cases penetrate the sea floor and form knolls with relief as great as $1,500 \mathrm{~m}$ (fig. 21). The higher knolls appear to be almost barren of sediments, although a few dozen meters of pelagic material on their flanks and crests might be essentially undetectable by seismic profiling. The lower knolls are commonly capped by several hundred meters of arched but not completely penetrated abyssal-plain sediments. Acoustic reflectors in these upper sediments are traceable for many kilometers into the adjacent undisturbed areas. Clearly, the growth of these isolated diapirs has been rapid relative to sedimentation rates and is active at present. In most cases, individual salt structures are separated by almost undeformed sediments and, especially toward the outer parts of the zone, do not connect with each other within the depths penetrated by our acoustic system. Because of the concentric relation of the zone of isolated structures to the central region, these stocks appear to have risen from the deeper edges of the main salt mass. Correlation of individual structures from line to line cannot be made because of the sparcity of data in the area, but the distribution of features suggests that the salt either occurs in ridges or that there is a strong northeasterly alinement of peaks, possibly related to deepseated ridges.

On the north and west sides of the belt of isolated diapirs, the strongly bedded continental-slope sediments have been folded (fig. 28, $C-C^{\prime}$ ) and sometimes thrust faulted by compressive forces created by the rising salt. Other more symmetrical folds appear to be the result of arching over growing but very deep salt stocks.

The zone of folds extends northward from the central region of slope diapirs and connects with the Sigsbee Knolls region of abyssal diapirs.

South of the central region of massive salt, another grouping of salt massifs appears to be present beneath deposits of the shelf and upper slope. The main body of salt bounded on the north and separated from the central salt mass by a belt of isolated diapirs, probably extends shoreward beneath the shelf and is associated with the salt domes of the
Isthmian salt basin in northern Tabasco. This salt basin was described as the oldest in southeastern Mexico by Viniegra (1971), who also reported evidence of yet another salt basin of possibly somewhat younger age to the southeast, extending through southern and central Guatemala and perhaps into western British Honduras.

At the other extreme, the abyssal diapirs of the Sigsbee Knolls region are far north of the Golfo de Campeche diapirs. They are mostly isolated structures, although a few appear to coalesce at depths discernible by reflection profiling (fig. 28, $A-A^{\prime}$, $E-F-G)$. Those structures that emerge from the sea floor have been described as knolls, whereas those "visible" only by acoustic means are called domes (Worzel and others, 1968). The former are fewest and form a discrete group, surrounded by diapirs whose tops are buried at various depths below the surface. The buried structures show no evidence of vertical movement since at least the beginning of deposition of the upper strongly bedded unit of abyssal turbidites approximately $400 \mathrm{~m}$ thick. By comparison with results from JOIDES drilling nearby, the base of this unit is the PleistocenePliocene boundary (Burk and others, 1969).

Although control lines are admittedly sparse (fig. 2), the grouping of diapiric forms in the Golfo de Campeche suggests that the salt may, to some extent, be concentrated in large domal masses, interconnected by thinner salt layers or regions where salt is absent. The Sigsbee knolls and domes in the abyssal plain are separated from the salt massifs of the central region by a long narrow belt of folded sediments in which no intrusive structures have been found. These folds could have originated over salt ridges similar to those postulated by Jones and others (1967) and Bryant, Antoine, Ewing, and Jones (1968) to have formed the Mexican Ridges. It is also conceivable that salt is thin or absent between the two diapiric regions and that the folded sediments formed by décollation as the basin tilted to the northwest.

At any rate, if the salt is not equally thick over the Campeche Knolls region, then it is likely that structural barriers confined original salt deposition to separate basins, or that such barriers have channelled the subsequent lateral migration of salt to the areas of its present concentration.

The zonation of salt structures strongly suggests northeasterly alinements, although the spacing of seismic lines was too great for actual correlation of ridge trends. This northeasterly trend also appears 
to be valid for fold crests in the area and has been noted in the salt structures of the Isthmian basin as well (Viniegra, 1971). According to current theories on the lateral migration of salt (Bornhauser, 1958; Ewing and Antoine, 1966; Selig and Wermund, 1966; Gussow, 1968), the ridges are approximately normal to the direction of salt flow and reflect the northwestward slope of the basement surface.

In reconstructing the history of the Gulf of Mexico, the origin of the Campeche-Sigsbee Knolls salt has been difficult to explain. The salt is essentially continuous from onshore to the abyssal plain, despite a general elevation change of some $4 \mathrm{~km}$, and its age is essentially identical at both endsMiddle to Late Jurassic (Kirkland and Gerhard, 1971; Viniegra, 1971); these factors pose problems for those who would have it a deep-water deposit (Ewing and others, 1962; Schmaltz, 1969).

To avoid some of these difficulties, Ewing and Antoine (1966) and Antoine and Bryant (1969) developed earlier ideas of de Cserna (1958) into a hypothesis that the Isthmian salt deposits extend northeastward under a large part of the Yucatan Peninsula. As the thickness of subsequent carbonate deposits grew and the salt attained mobility under the resulting pressures, it was prevented from migrating upward by the competent limestone and was thus forced to flow laterally toward the basin. Once clear of the limestone cap, the mobile salt rose diapirically through incompetent clastic material to form a chain of diapirs north and west of the Yucatan Peninsula.

The Kane seismic records neither prove nor refute this hypothesis but provide new evidence which must be considered in any theory of salt sources in the southwestern gulf. Between the Campeche and Sigsbee diapiric group, the absence of diapirs suggests that salt thins drastically; this seems to rule out the possibility that salt has migrated basinward beneath the abyssal-plain sediments from an original source on the Isthmus. Apparently the salt has thus had a history unlike that postulated for salt in the northwest gulf.

The evidence for two salt basins in the Isthmian region (Viniegra, 1971) couled with the separation of the Sigsbee and Campeche diapirs suggests that the salt is related to a chain of salt basins that once formed a semicircle around the western border of the ancestral Yucatan Peninsula. Whether these basins were beneath the limestone platform or whether they were essentially where the salt concentrations are at present, they have subsided dramatically.

\section{EASTERN GULF OF MEXICO CARBONATE PROVINCES}

BANCO DE CAMPECHE

A lithologic change of profound significance occurs in the continental margins of the Gulf of Mexico across a line drawn from Campeche Canyon in the southwest to De Soto Canyon in the northeast (fig. 1). The accompanying structural differences are no less important. To the northwest, the dominant factor in the post-Cretaceous development of the gulf has been the basinward migration of the continental margin as offlapping wedge after wedge of land-derived Tertiary sediments filled the subsiding Gulf Coast geosyncline. Southeast of this line, however, continent-derived clastic materials were not available in similar quantities, and the the direction of growth of the continental margins was principally vertical as carbonate sediments accumulated on shallow shelves. The resulting carbonate banks of Campeche and western Florida are therefore characterized by steep seaward-facing escarpments and great thicknesses of limestone and evaporites which formed as the upper surfaces of these deposits remained essentially at sea level while their bases subsided.

Banco de Campeche is the name generally applied to the submerged northern and western parts of the Yucatan platform. Structurally and stratigraphically, it is one of the least known regions of the Gulf of Mexico; only six wells on the Yucatan Peninsula and scanty geophysical data provide clues to its tectonic history (Antoine and Gilmore, 1970). Much of the land area adjacent to the shelf is a region of karst topography, and seismic-reflection profiles across the outer regions of the shelf show buried karst topography in that region as well (fig. 22). Thus, for much of its later history, at least, surface drainage has been of little importance to shelf construction, and sediments are the products of biological and chemical precipitation.

According to Logan and others (1969), shelves in the Gulf-Caribbean region can be grouped into two broad categories: (1) Protected shelf lagoons and (2) open, deeply submerged, inclined shelves. The Yucatan and West Florida shelves are considered to be examples of the second category.

The present shelf area extends $180-300 \mathrm{~km}$ seaward of the shoreline to a slope break in water depths varying from about $170-270 \mathrm{~m}$. Along the outer part of the western and northern shelf is a discontinuous chain of coral reefs and banks. These features offer no barrier to waves and wind-driven 
currents originating in the gulf, which sweep unimpeded across the shelf (Logan and others, 1969).

Seismic profiling around the outer part of the shelf indicates some modification to the shelf edge during changes of relative sea level. Some offlap and seaward pinchout of sedimentary lenses occurs, and prominent terrace levels have been reported at about $100-120$ feet $(30-37 \mathrm{~m}), 170-210$ feet (52-64 $\mathrm{m})$, and $300-450$ feet $(92-127 \mathrm{~m})$ below present sea level (Logan and others, 1969).

Relatively steep continental slopes surround the Banco de Campeche on three sides, although by no means are they uniform from place to place. The slope on the west side of the bank is one of the steepest and smoothest parts (fig. 23, pl. 1) ; with an inclination of more than $20^{\circ}$, it drops more than $3.25 \mathrm{~km}$ to form the eastern wall of Campeche Canyon. The northwest-facing sector of the Campeche slope has the lowest average inclination and the most rugged topography. Strongly scarred by canyons and slumps, the western part of the central slope has been more influenced by erosion than has any other comparable region in the gulf. The average slope is about $12^{\circ}$ in the central part, and acoustic profiles (fig. 23) show canyons incised to depths of more than $1 \mathrm{~km}$ from west of long $91^{\circ} \mathrm{W}$. to the mouth of Campeche Canyon. The northeast-facing sector is divided into upper and lower slopes. The upper slope has a maximum width of about 200 kilometers, an average declivity of about $5^{\circ}$, and a relatively smooth surface. The lower slope is steep, approaching $34^{\circ}$, and its seaward face forms a smooth concave profile which passes beneath abyssal deposits north of the Straits of Florida (pl. 1, $C-C^{\prime}$ ).

A continental-rise sediment section is absent at the base of the Campeche slope. On the west, the foot of the slope is buried by turbidite deposits in Campeche Canyon. The foot of the northwest slope is covered by slump masses and by turbidites of the Sigsbee Plain, and to the northeast, flat-lying deposits of the Mississippi Fan onlap the slope-face reflector.

An important aspect of the architecture of the Banco de Campeche is the presence, under its outer slope, of a reef of probable Early Cretaceous age near lat $24^{\circ} \mathrm{N}$., long $86^{\circ} \mathrm{W}$. (fig. 7). The reef was first noted by Ewing and Ewing (1966) in early profiles across the Campeche and West Florida Escarpments, but the concept that this structure may be part of a gulf-girdling reef system was formulated by Antoine, Bryant, and Jones (1967) and Uchupi and Emery (1968). Although the earliest evidence for the existence of a Campeche reef came from seismic-reflection profiles, the first positive proof that such a feature underlies the Campeche Escarpment was provided by the dredge hauls of Bryant and others (1969).

According to Antoine, Bryant, and Jones, (1967, p. 258), the reef at the escarpment face appears in seismic profiles as “*** (1) an 'anticline' in the subsurface near the scarp; (2) an apparent thinning of beds across the fold; (3) an increase in the sharpness of the fold with depth; and (4) an apparent outcrop of beds on the scarp."

From examination of the Kane profiles, the reef does not appear to extend completely around the perimeter of the Banco de Campeche, as hypothesized by Uchupi and Emery (1968), but is best developed in the area in and just north of Catoche Tongue (fig. 31, $B-B^{\prime}$ ). Dredge samples reported by Bryant and others (1969) from the scarp in that general region contained forereef or forebank fauna of Albian or late Aptian age. The Kane profiles show possible reef development as far west as the Campeche scarp crossing of line D-10 (pl. $1, C-C^{\prime}$ ), but beyond this point no acoustic evidence of reef structure can be seen. Disappearance of the reef could be due to various reasons: (1) It might be present but intermittent and missed in the wide line spacing; (2) it may have been made unrecognizable by erosion west of long $91^{\circ} \mathrm{W}$.; or (3) conditions may not have been favorable for reef building on the northwest and west sides of the Yucatan peninsula during Cretaceous time. On the basis of the distribution of Cretaceous reefs around a knoll in the approach to the Straits of Florida, Bryant and others (1969) suggested that "a proto-Florida Current" flowed through the area during the Early Cretaceous. If the present movement of oceanic waters westward and northwestward across the Banco de Campeche (Logan and others, 1969) is similarly related to paleocurrent directions, the construction of large barrier reefs north and west of the peninsula may not have been possible.

\section{WEST FLORIDA MARGIN}

In most respects, the west Florida continental margin is analogous to the Banco de Campeche. Separated by a gap less than $150 \mathrm{~km}$ wide, these two platforms form part of a vast area of shallowwater carbonate and evaporite accumulation which also includes the Bahamas. Seismic-refraction studies on the Campeche and west Florida platforms indicate that both are underlain by flat-lying beds with similar seismic velocities at similar depths 
(Antoine and Ewing, 1963). Furthermore, correlations of velocity layers with the stratigraphy from wells on the Florida and Yucatan peninsulas indicate the same ages associated with similar velocity ranges on both platforms, leading Antoine and Pyle (1970) to the conclusion that these two banks have had similar histories.

The surface of the West Florida Shelf, like that of the Banco de Campeche, is one of low relief broken only by reef structures or shoreline features associated with former periods of lowered sea level. Such features are most significant on the outer shelf where Jordan and Stewart (1959) have described Howell Hook, a drowned barrier spit and lagoon at depths of 140-185 m. In addition, many smaller spit and lagoon complexes and small reefs were shown

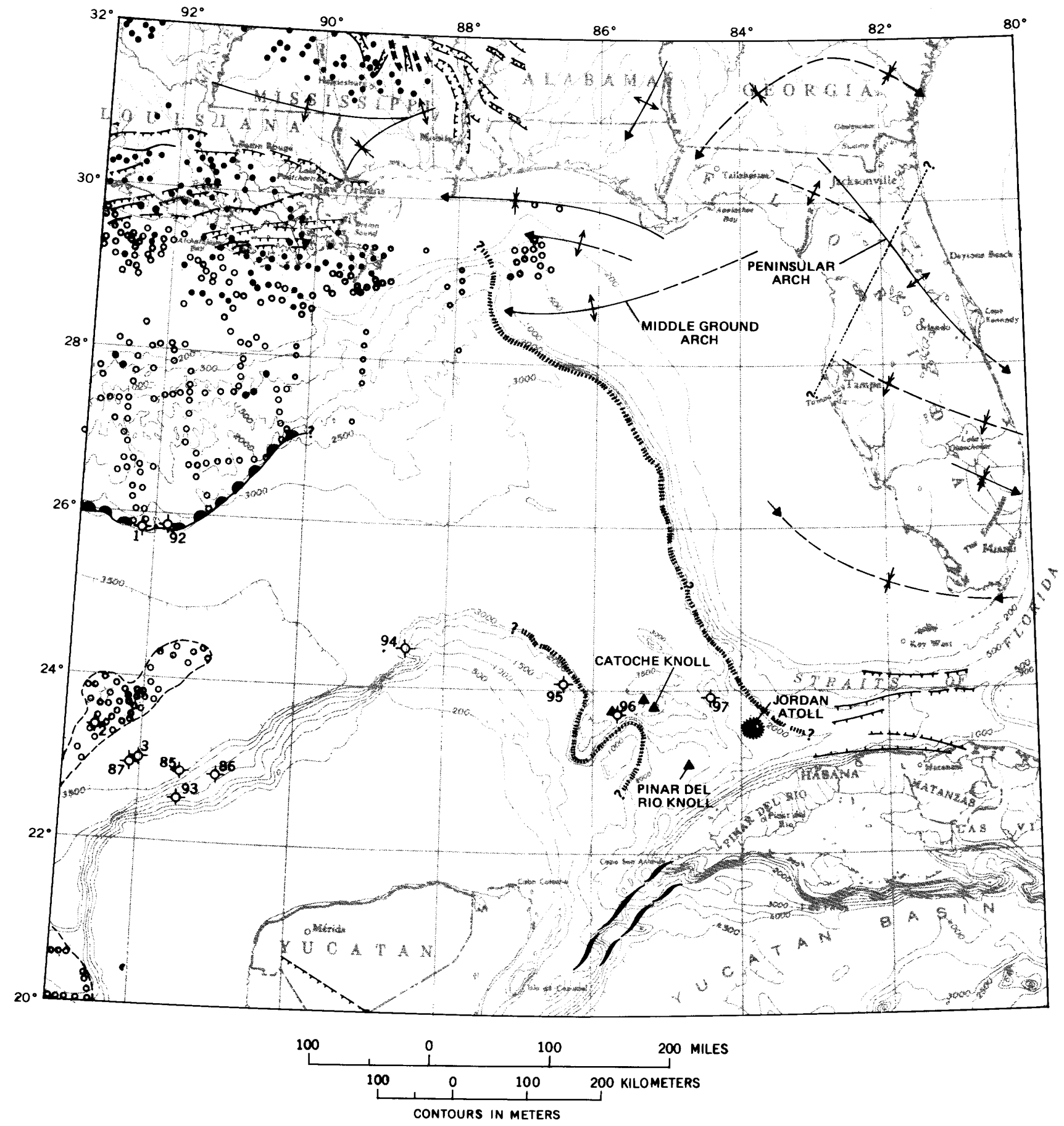

Figure 7.-Tectonic sketch map of eastern Gulf of Mexico and adjacent regions showing principal structural formation given in figure 4. 
by Ballard and Uchupi (1970) to be grouped around the 60 - and $160-\mathrm{m}$ depth contours. A living reef with an area of more than $750 \mathrm{~km}^{2}$ and a relief of as much as $18 \mathrm{~m}$ (Bergantino, 1971) is called Florida Middle Ground and is prominent on the shelf northwest of Tampa.

The standard, single-channel methods of continuous seismic-reflection profiling are generally not

\section{EXPLANATION}

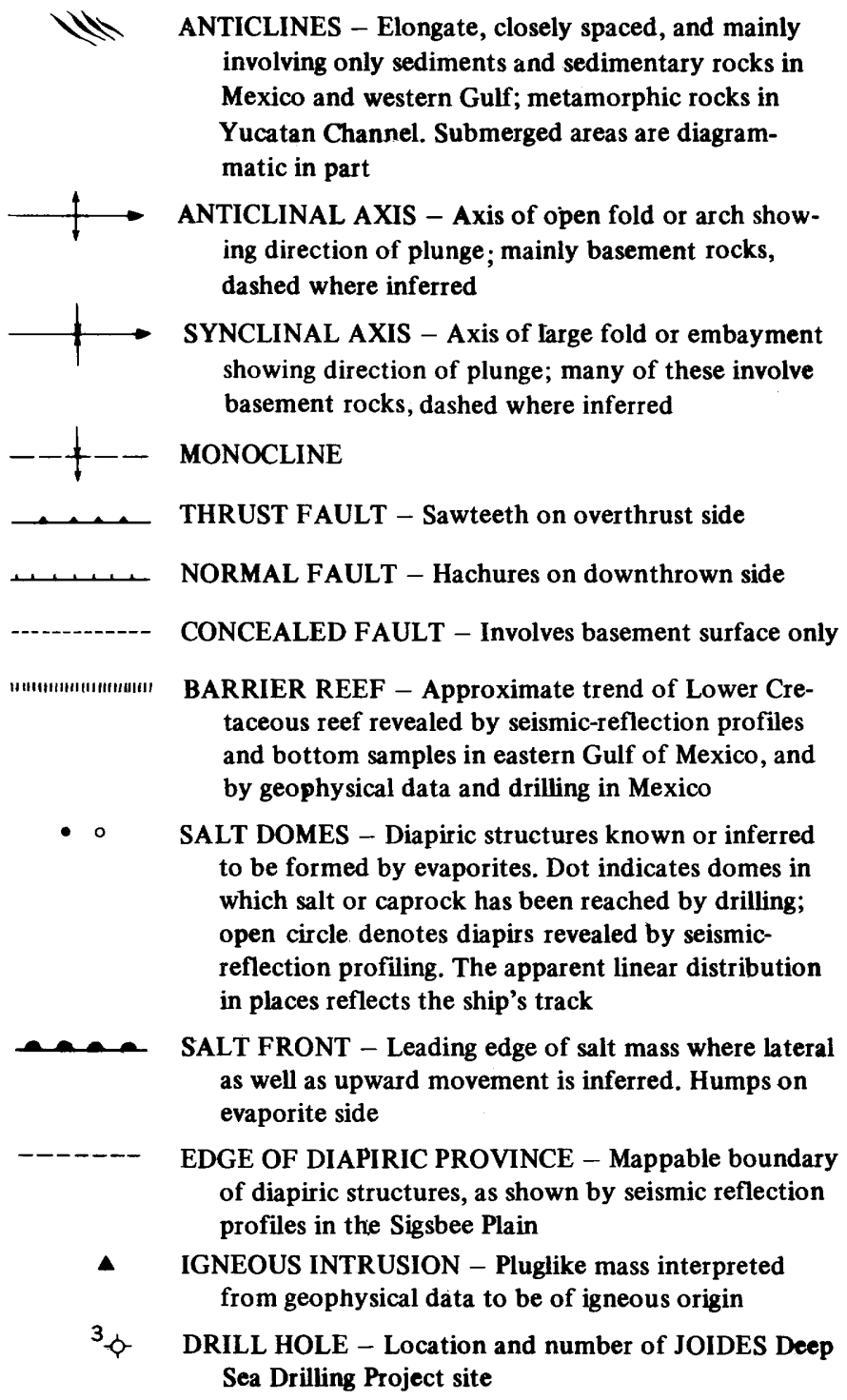

trends and features and JOIDES core sites. Sources of in- successful in obtaining structural information from the southern part of the West Florida Shelf. The competence of the carbonate beds so rapidly attenuates the outgoing sound pulses and so strongly reflects acoustical energy, that multiple echoes overwhelm the data, and such records are virtually useless unless costly techniques of data enhancement are used. Consequently, the interior framework of that region is little known except from the more generalized refraction work (Antoine and Ewing, 1963) and a few onshore and nearshore wells (Oglesby, 1965). Data from these sources indicate that the southern half of the shelf is a structural basin formed in Early Cretaceous time (fig. 7). The south Florida basin covers approximately 77,000 square miles under both shelf and peninsular Florida and, during Mesozoic-Cenozoic time, collected as much as 12,000 feet of carbonate and evaporite deposits (Oglesby, 1965; Antoine and Ewing, 1963).

The West Florida Escarpment forms the western boundary of the continental margin off Florida and separates the continental slope from the abyssal gulf floor (fig. 1). With a smooth, steeply sloping face in the north, and a gullied lesser gradient south of about lat $27^{\circ} \mathrm{N}$., the West Florida Escarpment (fig. 25) is remarkably similar to the escarpments surrounding much of Banco de Campeche. Cores and dredge samples recovered from the face of the escarpment have indicated that its lower slopes, like the eastern parts of the Campeche slope, also originated as a Lower Cretaceous reef that has since subsided approximately $2.5 \mathrm{~km}$ (Antoine and others, 1967). Seismic-reflection profiling in the area has tended to support this interpretation, as most records show a subsurface high associated with the scarp and a marked eastward dip of reflectors off its buried landward flank. Two widespread reflecting horizons which can be traced in the vicinity of De Soto Canyon landward for many kilometers and as far south as lat $27^{\circ} 30^{\prime} \mathrm{N}$., have been identified as the tops of Upper and Lower Cretaceous beds by seismic-refraction data and information from oil companies (Antoine and others, 1967).

Although the buried reef is thought to become intermittent south of lat $27^{\circ} \mathrm{N}$. (Pyle and others, 1968), it appears to persist in that direction at least into the Straits of Florida.

\section{CONTINENTAL MARGIN, NORTHEASTERN GULF OF MEXICO}

The northeastern Gulf of Mexico is a region of structural and lithologic transition. At the juncture 
of western clastic deposition and the eastern carbonate embankment, it is, in many respects, the counterpart of the eastern Golfo de Campeche, with the addition of a major source of terrigenous sediments. The continental margin in this part of the gulf attained its present form when the outbuilding prism of terrigenous sediments from the northwest buried the old Cretaceous reef off northern Florida and intertongued with the later Cenozoic carbonate deposits of the west Florida platform.

On the lower continental slope, the change in lithology is marked by a reentrant, or broad structural valley, referred to as De Soto valley by Martin (1972) to distinguish it from the De Soto Canyon of unrelated origin to the northeast (fig. 26, 27). The northwest wall of this valley is the face of the gulfward-prograding clastic embankment and is composed of a great thickness of mostly unconsolidated sediments of Tertiary age. The slope is relatively narrow $(<70 \mathrm{~km})$, has an inclination of $2^{\circ}-3^{\circ}$, and merges imperceptibly westward into the Mississippi Fan. The irregular topography of the embankment is locally marked by small erosional channels and by hummocks believed to be related to salt diapirism. Bedding within the slope generally conforms to the sea floor but is interrupted in places by buried channels and slump features. Growth faults and diapirs are much less common than in the continental slope off Texas.

The southeast wall of the reentrant is formed by the West Florida Escarpment which undergoes progressively deeper burial to the northeast until it eventually disappears beneath the spreading clastic deposits (fig. 25, $B-B^{\prime}$; fig. 26). In this region, the escarpment is a smooth steep bulwark at the base of an upper slope more than $100 \mathrm{~km}$ wide. Evidence from the Kane profiles (Martin, 1972) suggests that the scarp is buried beneath the terrigenous embankment north of the valley and continues northnorthwest toward the Mississippi coastline. The acoustic definition of the barrier reef was not recorded in the buried part of the scarp, either because the reef is absent or discontinuous north of the valley, or because the seismic penetration was insufficient to detect it. The smooth gulfward bulge of the escarpment clearly shows the growth of the Lower Cretaceous reef about the nose of the Middle Ground arch (Martin, 1972).

The only significant feature which interrupts the smooth topography of the upper slope is the S-shaped De Soto Canyon (fig. 27) surveyed by Jordan (1951). Harbison (1968) described the geology of the canyon and attributed its origin and course to a combination of late Tertiary erosion, deposition, and structural control by diapiric features clustered in the vicinity. The landward and seaward extensions of the canyon exist in the subbottom as buried channels.

The diapiric features clustered in the vicinity of the De Soto Canyon (figs. 7, 27), though not proven by drilling, are believed to be salt domes (Antoine and others, 1967; Harbison 1967, 1968). The possible occurrence of Louann Salt in the subsurface of the Florida Panhandle has been suggested by Marsh (1967), and many other diapirs and topographic prominences believed related to salt piercement have been recorded by Uchupi and Emery (1968) and Antoine and Gilmore (1970). Diapirs within the terrigenous embankment are not uncommon, but their distribution is sparse as compared with those in the northwestern gulf. Diapiric features are unknown south and east of the De Soto Canyon area; thus, the northeast-gulf domes may represent either the eastern margin or a drastic thinning of the evaporites of the gulf coast salt basin. Alternatively, competent limestone beds composing the west Florida platform south of the canyon may have prevented vertical migration of the salt (Antoine and Gilmore, 1970).

\section{CENTRAL GULF OF MEXICO BASIN}

The central or abyssal Gulf of Mexico covers a $356,000-\mathrm{km}^{2}$ expanse of sea floor which is generally below a depth of $2,500 \mathrm{~m}$ and includes three distinct geomorphic provinces, (1) the continental rise, (2) the Sigsbee Plain, and (3) the Mississippi Fan (fig. 1 ). It is sharply bounded on the north, east, and south by the Sigsbee, West Florida, and Campeche Escarpments but is open to the Atlantic Ocean and Caribbean Sea via the Straits of Florida and the Yucatan Channel. In the western gulf and the Golfo de Campeche, the flat abyssal floor rises gradually to merge with the gradient of the continental slope.

\section{CONTINENTAL RISE}

The continental rise is a broad sedimentary apron onlapping the base of the Sigsbee Escarpment and Rio Grande escarpment and sloping gently about 6 $\mathrm{m} / \mathrm{km}$ to merge with the flat abyssal floor of the Sigsbee Plain generally along the 3,500-m contour. It stretches westward from the toe of the Mississippi Fan to southeast of the Rio Grande Delta where there is a gradual loss of topographic definition. Other investigators have included in their discussions of a continental rise the lower slopes fronting 
the Mexican Ridges and the Campeche Escarpment in the western and southern gulf, as well as the regions of sea floor between the ridges and the Campeche Knolls and the Campeche Canyon (Uchupi, 1967; Bergantino, 1971). However, the Kane profiles do not reveal a clastic wedge section beneath these regions.

The rise is composed of a sedimentary prism having a maximum thickness of about $760 \mathrm{~m}$ at its base against the Sigsbee Escarpment and thinning to a pinchout beneath the horizontal beds of the abyssal plain. Wilhelm and Ewing (1972) noted a general lack of stratification within this wedge and concluded that the rise has resulted from many gravitational flows originating on the unstable continental slope. The Kane profiles (figs. 11-14; pl. 1, $A-A^{\prime}$ ) also reveal that individual flows, acoustically represented by discontinuous and incoherent reflections, often are separated by considerable thicknesses of well-stratified deposits. Similar flowlike masses are seen interbedded in the thick sections beneath the slope in the Campeche Canyon and in the region between the Mexican Ridges and the Campeche Knolls (fig. 23, $B-B^{\prime}$; pl. 1, $D-D^{\prime}, E-E^{\prime}$, $\left.F-F^{\prime}\right)$.

In the southern gulf, a topographically rough apron of sediments separates the flat abyssal floor from the rugged face of the Campeche Escarpment (fig. 23, $A-A^{\prime}$ ). The acoustical character of this apron suggests that it is composed of blocks of strata slumped basinward from the scarp (Wilhelm and Ewing, 1972) and chaotically interbedded with turbidite deposits.

\section{SIGSBEE PLAIN}

The Sigsbee Plain occupies the deepest part of the gulf basin and has a maximum depth of about 3,700 $\mathrm{m}$. The abyssal floor is essentially flat, having a slope of less than 1:8,000 (Uchupi, 1967), and, except for the prominence of the Sigsbee Knolls (fig. $\left.28, A-A^{\prime}\right)$, it is featureless. The knolls stand 100 $200 \mathrm{~m}$ above the level of the plain and are primarily clustered near its center, but many salt domes that do not penetrate the surface extend in a narrow belt to the northeast and southwest (fig. 6). Folding believed related to deep-seated salt movement has imparted some topographic irregularity to the abyssal floor (fig. 28, $C-C^{\prime}$ ).

The flat abyssal floor is the top of a well-stratified section of horizontally disposed Pliocene-Holocene turbidites interbedded with pelagic oozes (Burk and others, 1969). The principal source of turbidites was the continental slope off the Mississippi River (Ew- ing and others, 1958), but significant contributions have been made by currents sweeping the Banco de Campeche (Davies, 1968). The section attains its maximum thickness of nearly $400 \mathrm{~m}$ in the vicinity of the Sigsbee Knolls and thins gradually northward onto and beneath continental-rise deposits (pl. 1, $\left.A-A^{\prime}\right)$ and more abruptly southward against the rough sedimentary apron fronting the Campeche Escarpment (fig. 23, $A-A^{\prime}$ ) ; to the west, the uppermost beds of the unit onlap and pinchout over continental-slope deposits (pl. $1, B-B^{\prime}$ ). Beneath this turbidite section, the dips of successively older beds increase northwestward toward the Sigsbee Escarpment (Bergantino, 1971). Cores from the JOIDES drilling on Challenger Knoll and in the plain to the southeast (Burk and others, 1969) reveal that since late Miocene time only pelagic deposits have accumulated on the crest of the knoll, although terrigenous turbidites were being deposited on the surrounding plain, and indicate that the knolls may have stood in relief since at least middle Tertiary time.

\section{MISSISSIPPI FAN}

The area and volume of the Mississippi Fan indicate the extent to which Quaternary deposition in the east-central gulf has been dominated by the Mississippi River system source. The fan covers a $160,000-\mathrm{km}^{2}$ area of gulf floor and includes the continental slope, rise, and abyssal-plain provinces between the West Florida, Campeche, and Sigsbee Escarpments. Its apex is the mouth of the Mississippi Trough southwest of the delta front (fig. 1), from which point the fan trends southeast for more than $600 \mathrm{~km}$ to the narrow gap between the Catoche Tongue and the southwest limits of the Florida platform. It can be subdivided into upper and lower fan regions on the basis of a change in slope, which generally occurs along the $2700-\mathrm{m}$ contour, and on a corresponding change in bottom topography (Huang and Goodell, 1970). The gradient of the upper fan is about $40 \mathrm{~m} / \mathrm{km}$, but it gradually diminishes to less than $1 \mathrm{~m} / \mathrm{km}$ on the outer margins of the lower fan.

The Mississippi Fan has been built from the voluminous sediment delivered to the gulf by the Mississippi River since early in the Pleistocene, an annual discharge estimated at more than 983 million tons of detritus and suspended load (Huang and Goodell, 1970).

The most striking feature of the upper fan is the broad, U-shaped Mississippi Trough which notches the shelf southwest of the Mississippi Delta and de- 
bouches onto the upper fan at a depth of about 1,650 $\mathrm{m}$. From this point, broad-leveed valleys extend toward the Sigsbee Plain and die out on the lower fan (fig. 30, $A-A^{\prime}$ ). Numerous smaller gullies, believed to result primarily from slumping (Shepard, 1955), corrugate the surface of the fan in the region seaward of the delta, terminating in fanlike aprons in water depths of about $70 \mathrm{~m}$ (Uchupi, 1967). In marked contrast to the upper fan, the lower fan is a broad almost featureless apron (fig. 30, $B-B^{\prime}$ ) which slopes gently to the eastern edge of the Sigsbee Plain and to the southeastern exits of the gulf.

The internal structure of the upper fan is made complex by numerous cut-and-fill features, levees, diapirs, and slump structures. Walker and Massingill (1970) reported that large-scale recently active slumps have affected an area on its surface of more than $56,000 \mathrm{~km}^{2}$. The complex and distorted beds of the upper fan grade downslope into stratified hemipelagic deposits which abut the Florida and Campeche Escarpments. These deposits are continuous with well-stratified Pleistocene sediments of the Sigsbee Plain and extend to the Sigsbee Escarpment where the continental-rise prism is sandwiched between fan deposits of Pleistocene and Holocene age (Wilhelm and Ewing, 1972). Along the extreme southeastern margin of the lower fan, the outermost fan deposits rest unconformably on rugged topography of older sedimentary units (fig. 28, $D-D^{\prime}$; fig. $34, A-B$ ).

\section{SOUTHEASTERN LIMITS OF THE GULF OF MEXICO}

None of the geologic provinces of the Gulf of Mexico basin and the transitions that occur from one province to another is more striking, and indeed less well understood, than the major tectonic transition along the southeastern limits of the gulf. Across the $100-\mathrm{km}$-wide region of moderate water depths $(1,000-3,000 \mathrm{~m})$ that includes the Straits of Florida and the Yucatan Channel, the relatively simple framework of the gulf abruptly joins the complex Laramide tectonic front of Cuba. The character and origin of the juncture are poorly known and beyond the scope of this report, but most observers separate the gulf basin from the Caribbean island arc, of which Cuba is a part, by either a down-faulted or strike-slip fault zone (Khudoley, 1967; Wilhelm and Ewing, 1972; Malloy and Hurley, 1970). The nature of the transition is further complicated by the apparent continuation of Cuban tectonic trends into the eastern margin of the Yucatan Peninsula (figs. $7 ; 34, C-F)$.
The southeasternmost region of the gulf is composed of three characteristically different sea-floor regions: (1) The Straits of Florida, which separate the Florida platform from the Cuban ridge; (2) the Yucatan Channel, similarly separating Cuba from the Banco de Campeche; and (3) an area of rugged sea floor, knolls, and sedimentary aprons at the northern juncture of these two straits (fig. 1).

\section{THRESHOLD OF THE GULF}

Extending from the toe of the Mississippi Fan to the foot of the Cuban ridge and the entrances to the Straits of Florida and the Yucatan Channel is a region of little-known geology composed of rugged sea floor, sedimentary aprons, and prominent knolls. It is divided into northeast and southwest sectors by a pronounced northwest-trending valley system which forks near long $84^{\circ} \mathrm{W}$. to conform with the axes of the straits and channel (fig. 7). The Kane profiles across this valley indicate that it is localized along a normal fault having stratigraphic displacement of about $700 \mathrm{~m}$ down to the southwest.

The area of rugged sea floor is principally restricted to the sector west of the fault valley where older sedimentary units, possibly Cretaceous carbonates and cherts (Worzel and Bryant, 1970), are shown by the Kane profiles to outcrop on the sea floor (fig. 34, $A-B$ ). The rugged topography appears to be mostly due to erosion, and only minor amounts of younger sediments have accumulated on the eroded surface. Many small erosional valleys have been reported from along the northern edge of both sectors by Bergantino (1971) who suggested a presubsidence erosional history for the region. Whether or not the erosion was accomplished in shallow or deep water, currents flowing through the Yucatan Channel apparently have prevented extensive deposition over much of the western threshold sector.

Southeast of Catoche Tongue near the southernmost extent of the Mississippi Fan deposits, acoustic basement rises to within $400 \mathrm{~m}$ of the bottom (fig. $34, A-B)$. South and east of this area, the bedded Cretaceous (?) section thickens toward the median valley and is interrupted in the subbottom by intrusivelike masses and several faults of easterly downthrow.

East of the median valley, the deep-water approach to the Straits of Florida has been topographically smoothed by an apron of sediments spread seaward from the southernmost extension of the West Florida Escarpment (fig. 31, $A-A^{\prime} ; 32, A-B$ ). This sedimentary blanket thins from about $200 \mathrm{~m}$ 
adjacent to the escarpment to pinchout above the east wall of the valley, a seaward thinning which Hurley (1964) suggested was due to gulfward transport of sediment through the Straits of Florida. JOIDES drilling (hole 97; Worzel and Bryant, 1970) near the northwestern edge of this sector encountered an Eocene-Pliocene section lying unconformably upon Upper Cretaceous limestones and cherts.

Several prominent knolls, which rise as much as $750 \mathrm{~m}$ above the surrounding sea floor, have been reported in this region (fig. 7, solid triangles). Jordan, Catoche, and Pinar del Rio Knolls were described by Pyle and others (1969) and Bryant and others (1969) who assigned their origins to mafic igneous intrusions on the basis of strong positive magnetic anomalies of 100-200 gammas. Evidence indicates that Jordan Knoll is an Early Cretaceous atoll ringed by a reef complex contemporaneous with the west Florida reef which formed either upon a preexisting igneous platform or was later intruded by an igneous mass. The Kane data revealed two previously unreported knolls in the vicinity of Catoche Tongue (figs. $7 ; 28, D-D^{\prime}$ ) both of which have acoustical and magnetic characteristics similar to the other knolls in this region.

\section{STRAITS OF FLORIDA}

The Straits of Florida are arms of the Atlantic which separate the Florida platform from the Bahama Banks and the Greater Antilles Ridge, of which Cuba is a part. The straits are floored by a narrow (40-100 km) arcuate trough extending more than $700 \mathrm{~km}$ south and west around the eastern and southern periphery of the Florida platform. The southern straits described herein, geologically unrelated to the northern strait (Malloy and Hurley, 1970), reach from Cay Sal Bank (fig. 1) south of Miami, Fla., into the gulf off northwestern Cuba.

The straits are fronted in the gulf by the southeasternmost extension of the West Florida Escarpment. Profiles across the scarp in this area (figs. 31, $\left.A-A^{\prime} ; 32, A-B\right)$ indicate the presence of the underlying Lower Cretaceous reef which is believed to continue southeastward where it is known in the subsurface of north-central Cuba east of Havana (Bryant and others, 1969).

The straits are underlain by a smooth graded gulfward-sloping valley floor, bounded on the north by the broad terraced Floridian slope and on the south by the narrow rugged slopes of the Cuban ridge. The Cuban slope is complicated by many large scarps with relief commonly in excess of $300 \mathrm{~m}$, nar- row terraces, and numerous reentrants or canyons (Malloy and Hurley, 1970). East of long $82^{\circ} \mathrm{W}$., the slope is terraced, but to the west, particularly near Havana, it is steep and continuous. Malloy and Hurley (1970) associated the Cuban scarps with the seaward projection of the Sierra de Jatibonica and Las Villas faults (fig. 7). Khudoley (1967) believed the Sierra de Jatibonica fault to be a deep-seated dislocation across which the Gulf of Mexico is separated from the tectonic complexities of the Caribbean.

Less steep and rugged is the terraced slope on the Florida side of the straits. The shelf break is smooth and arcuate in outline along its $400-\mathrm{km}$ course through the straits. Below the shelf off the Florida Keys is the broad $(30 \mathrm{~km})$ arcuate Pourtales Terrace which averages about $225 \mathrm{~m}$ in depth. The terrace floor is marked by many closed depressions, low rises, small valleys, and, along its outer margin, isolated reef pinnacles. The karstlike features were said by Jordan (1954) to have been formed subaerially during the Pleistocene, but Malloy and Hurley (1970) suggested instead that karst formation has taken place under water because of solution and collapse caused by seeping waters from the underlying Florida aquiclude. The terrace is fronted for nearly $115 \mathrm{~km}$ by the Pourtales Escarpment which rises nearly $300 \mathrm{~m}$ in less than $1 \mathrm{~km}$. The slope below the scarp is smooth, convex upward, and fronted by the northeast-trending Mitchell Escarpment (fig. $32, C-D)$; another small scarp paralleling the Mitchell Escarpment lies to the south near the axis of the straits. The escarpments that interrupt the slope are believed associated with normal faulting (fig. 7), but displacements are thought to be of less than regional tectonic significance (Jordan and others, 1964 ; Malloy and Hurley, 1970).

West of about long $82^{\circ} \mathrm{W}$. the slope broadens into a fan-shaped, convex-upward declivity which extends from the shelf break to the floor of the straits and the extension of the West Florida Escarpment. The smooth outline of the slope is indented by many small valleys described by Jordan and Stewart (1961), who attributed them to turbidity erosion. A system of small, closely spaced leveed valleys trending almost due north, known as the Agassiz Valleys (fig. 33), is one of the most striking topographic features in the straits; to the west is the larger, dendritic Tortugas Valley system.

Of common occurrence on the floor of the straits are depositional rises which occur along the bases of prominent escarpments (fig. 32, $C-D$ ). The features are believed formed by periodic deposition by bottom-contour currents. These currents, when chan- 
neled against a scarp, create a high-energy zone of nondeposition adjacent to the scarp; however, as in levee formation, deposition occurs seaward in a zone of decreasing energy to produce the sedimentary anticline (Malloy and Hurley, 1970). Most of these features show westward-trending noses suggesting westerly bottom flow counter to the Florida Current.

Despite the considerable number of investigations conducted in the Straits of Florida, the origin of the straits remains speculative. They have been attributed to submarine erosion (Agassiz, 1888), combinations of subsidence, upbuilding, and restricted sedimentation (Uchupi, 1966), and faulting (Pressler, 1947). Malloy and Hurley (1970), noting the extensive faults along the Cuban slope postulated the straits to be a half-graben downfaulted against Cuba and hinged in northern Florida. The straits, in existence since latest Jurassic time (Bryant and others, 1969), have probably formed from the combined effects of subsidence due to downfaulting, upbuilding of the Florida platform, local erosion, and restricted deposition resulting from the flow of a proto-Florida Current.

\section{YUCATAN CHANNEL}

The narrow straits (about $180 \mathrm{~km}$ ) separating the northeastern corner of the Yucatan Peninsula from the western tip of Cuba are generally called the Yucatan Channel. The channel floor has a sill depth of about $2,000 \mathrm{~m}$ and a fishhook trend, the shank of the hook oriented northeast, parallel to the topographic trends of the eastern Yucatan margin (fig. 7). The channel bends sharply eastward off the tip of Cuba and slopes steeply to the floor of the Yucatan Basin in the Caribbean; in the gulf, it leads into the rugged bottom between the Campeche Escarpment and the Cuban slope. The Kane profiles reveal that the Campeche Escarpment and its underlying Cretaceous reef do not continue along the eastern Yucatan margin south of about lat $23^{\circ} \mathrm{N}$. (fig. 34, E-F). The slope on the Yucatan side of the channel is gentle and smooth from the terminus of the escarpment to about lat $22^{\circ} \mathrm{N}$, where it steepens and becomes rugged.

The continental margin on the Yucatan side of the channel is marked by elongate ridges which parallel the coastline (Baie, 1970) and then curve northeastward to cross the channel and trend toward the western tip of Cuba (figs. $7 ; 34, C-F$ ). Sericitic schists and marble fragments yielding Late Cretaceous metamorphic dates were recovered in dredge hauls across the flank of a ridge in the channel (J. G. Vedder, oral commun., 1971). The lithologic simi- larity between these samples and the metamorphic rocks exposed on the Isla de Piños, Cuba, suggests a structural link between Cuba and eastern Yucatan (Vedder and others, 1971; Baie, 1970). The ridges appear to have acted as effective barriers to seaward sediment transport, ponding as much as $1.5 \mathrm{~km}$ of material behind their gulfward flanks (fig. 34, $C-F$; Vedder and others, 1971, fig. 2).

\section{CONCLUSIONS}

The purpose of this paper has been to discuss the principal geologic structures that characterize the various tectonic provinces of the Gulf of Mexico and to show these structural types as they appear on seismic-reflection profiles. A brief summary of the concepts that guide current thinking on gulf structures has been presented to highlight salient problems and, it is hoped, to stimulate further investigation.

The Kane survey has made clear the fact that despite the importance of this small ocean basin to the nations that surround it, and despite the density of data collected in certain areas, the origin and evolution of the Gulf of Mexico are far from well known. Although knolls in the deep basin and hummocks on the continental slope have been identified as salt domes, the depositional environment and subsequent migration of the salt and even its present extent are still conjectural. The discovery of shallowwater fauna at great depths on the Florida and Campeche Escarpments, accompanied by geophysical indications of reef masses behind the scarp face opened new possibilities for fruitful investigation, but the problems of initiation of reef growth and the early relationships of reefs to evaporite basins remain unresolved. In the threshold region between the Gulf of Mexico and the Caribbean Sea, recent studies have discussed possible origins for many of the local features, but the larger question of whether gulf and Caribbean represent an original basin separated by orogenesis or separate basins welded together by plate movements can only be speculated upon.

Many other intriguing questions remain unanswered. What caused the folding of the Mexican Ridges? Why is the northern slope of Banco de Campeche eroded? What is the nature of Mesozoic rocks beneath the Sigsbee Plain? What lies below them? What is the composition of the crustal material that underlies the gulf? Some of these questions undoubtedly will be answered by research now in progress, whereas others will only yield to intensive long-range study. 


\section{REFERENCES CITED}

Agassiz, Alexander, 1888, Three cruises of the Blake: New York, Houghton-Mifflin, 314 p.

Amery, G. B., 1969, Structure of Sigsbee scarp, Gulf of Mexico: Am. Assoc. Petroleum Geologists Bull., v. 53, no. 12 , p. 2480-2482.

Antoine, J. W., and Bryant, W. R., 1969, Distribution of salt and salt structures in Gulf of Mexico: Am. Assoc. Petroleum Geologists Bull., v. 53, no. 12, p. 2543-2550.

Antoine, J. W., Bryant, W. R., and Jones, B. R., 1967, Structural features of continental shelf, slope, and scarp, northeastern Gulf of Mexico: Am. Assoc. Petroleum Geologists Bull., v. 51, no. 2, p. 257-262.

Antoine, J. W., and Ewing, J. I., 1963, Seismic refraction measurements on the margins of the Gulf of Mexico: Jour. Geophys. Research, v. 68, no. 7, p. 1975-1996.

Antoine, J. W., and Gilmore, J. C., 1970, Geology of the Gulf of Mexico: Tectonophysics, v. 10, no. 5-6, p. 477-

Antoine, J. W., and Harding, J. L., 1963, Structure of the continental shelf, northeastern Gulf of Mexico: Texas A. \& M. Univ. Tech. Rept. $63-13 \mathrm{~T}, 18 \mathrm{p}$.

- 1965, Structure beneath continental shelf, northeastern Gulf of Mexico: Am. Assoc. Petroleum Geologists Bull., v. 49 , no. 2, p. 157-171.

Antoine, J. W., and Pyle, T. E., 1970, Crustal studies in the Gulf of Mexico: Tectonophysics, v. 10, no. 5-6, p. 477494.

Applin, P. L., and Applin, E. R., 1965, The Comanche Series and associated rocks in the subsurface in central and south Florida: U.S. Geol. Survey, Prof. Paper 447, 84 p.

Baie, L. F., 1970, Possible structural link between Yucatán and Cuba: Am. Assoc. Petroleum Geologists Bull., v. 54 , no. 11, p. 2204-2207.

Ball, M. M., and Harrison, C. G. A., 1969, Origin of the Gulf of Mexico and Caribbean and implications regarding ocean ridge extension, migration, and shear: Gulf Coast Assoc. Geol. Socs. Trans., v. 19, p. 287-294.

Ballard, J. A., and Feden, R. H., 1970, Diapiric structures on the Campeche shelf and slope, western Gulf of Mexico: Geol. Soc. America Bull., v. 81, no. 2, p. 505512.

Ballard, R. D., and Uchupi, Elazar, 1970, Morphology and Quaternary history of the continental shelf of the Gulf Coast of the United States: Bull. Marine Sci., v. 20, no. 3 , p. 547-559.

Bergantino, R. N., 1971, Submarine regional geomorphology of the Gulf of Mexico: Geol. Soc. America Bull., v. 82, no. 3, p. 741-752.

Bornhauser, Max, 1958, Gulf Coast tectonics: Am. Assoc. Petroleum Geologists Bull., v. 42, no. 2, p. 339-370.

Bryant, W. R., Antoine, J. W., and Ewing, Maurice, 1968, Structure of the Mexican continental shelf and slope [abs.]: Geol. Soc .America Spec. Paper 101, Abs. for 1966, p. 28-29.

Bryant, W. R., Antoine, J. W., Ewing, Maurice, and Jones B. R., 1968, Structure of Mexican continental shelf and slope, Gulf of Mexico: Am. Assoc. Petroleum Geologists Bull., v. 52, no. 7, p. 1204-1228.

Bryant, W. R., Meyerhoff, A. A., Brown, N. K., Jr., Furrer, M. A., Pyle, T. E., and Antoine, J. W., 1969, Escarpments, reef trends, and diapiric structures, eastern Gulf of Mexico: Am. Assoc. Petroleum Geologists Bull., v. 53 , no. 12 , p. $2506-2542$.
Burk, C. A., Ewing, Maurice, Worzel, J. L., Beall, A. O., Jr., Berggren, W. A., Bukry, David, Fischer; A. G., Pessagno, E. A., Jr., 1969, Deep-sea drilling into the Challenger Knoll, central Gulf of Mexico: Am. Assoc. Petroleum Geologists Bull., v. 53, no. 7, p. 1338-1347.

Creager, J. S., 1958, A canyon-like feature in the Bay of Campeche: Deep-Sea Research, v. 5, no. 2, p. 169-172.

Cserna, Zoltán de, 1958, Notes on the tectonics of southern Mexico, in Weeks, L. G., ed., Habitat of oil-A symposium: Tulsa, Okla., Am. Assoc. Petroleum Geologists, p. 523-532.

Curray, 'J. R., 1960, Sediments and history of Holocene transgression, continental shelf, northwest Gulf of Mexico, in Shepard, F. P., Phleger, F. B., and van Andel, T. H., eds., Recent sediments, northwest Gulf of Mexico: Tulsa, Okla., Am. Assoc. Petrolèum Geologists, p. 221-266.

Currie, J. B., 1956, Role of concurrent deposition and deformation of sediments in development of salt-dome graben structures [Mississippi]: Am. Assoc. Petroleum Geologists Bull., v. 40, no. 1, p. 1-16.

Davies, D. K., 1968, Carbonate turbidites, Gulf of Mexico: Jour. Sed. Petrology, v. 38, no. 4, p. 1100-1109.

deJong, A., 1968, Stratigraphy of the Sigsbee scarp from a reflection survey [abs.]: Soc. Exploration Geologists, Fort Worth Mtg., Program, p. 51.

Eardley, A. J., 1954, Tectonic relations of North and South America: Am. Assoc. Petroleum Geologists Bull., v. 38 , no. 5 , p. $707-773$.

Ewing, J. I., Antoine, J. W., and Ewing, Maurice, 1960, Geophysical measurements in the western Caribbean Sea and in the Gulf of Mexico: Jour. Geophys. Research, v. 65 , no. 12 , p. $4087-4126$.

Ewing, J. I., Worzel, J. L., and Ewing, Maurice, 1962, Sediments and oceanic structural history of the Gulf of Mexico: Jour. Geophys. Research, v. 67, no. 6, p. 2509-2527.

Ewing, Maurice, and Antoine, J. W., 1966, New seismic data cencerning sediments and diapiric structures in Sigsbee Deep and continental slope, Gulf of Mexico: Am. Assoc. Petroleum Geologists Bull., v. 50, no. 3, pt. 1, p. $479-504$.

Ewing, Maurice, Ericson, D. B., and Heezen, B. C., 1958, Sediments and topography of the Gulf of Mexico, in Weeks, L. G., ed., Habitat of oil-A symposium: Tulsa, Okla., Am. Assoc. Petroleum Geologists, p. 955-1053.

Ewing, Maurice, and Ewing, J. I., 1966, Geology of the Gulf of Mexico, in Exploiting the ocean-Marine Technology Soc., 2nd Ann. Conf. and Exhibit, 1966, Trans. Supp.: Washington, D.C., Marine Technology Soc., p. 145-164.

Ewing, Maurice, Worzel, J. L., and Burk, C. C. A., 1969, Introduction, in Initial reports of the Deep Sea Drilling Project - v. 1, Covering Leg I of cruises of Drilling Vessel Glomar Challenger, Orange, Tex., to Hoboken, N.J., Aug.-Sept. 1968: Washington, D.C., U.S. Govt. Printing Office, p. 3-9.

Franco, Alvaro, 1970a, Big oil province shapes up off Mexico: Oil and Gas Jour., July 27, p. 72-75.

$1970 \mathrm{~b}$, This part of Mexico looks promising: Oil and Gas Jour., Sept. 28, p. 134, 136.

Freeland, G. L., and Dietz, R. S., 1971, Plate tectonic evolution of Caribbean-Gulf of Mexico region: Nature, v. 232 , no. 5305 , p. $20-23$, July 2 issue. 
Garrison, L. E., and Berryhill, H. L., Jr., 1970, Possible seaward extension of the San Marcos Arch [abs.]: Geol. Soc. America Abstracts with Programs, v. 2, no. 4, p. 285-286.

Gealy, E. L., 1955, Topography of the continental slope in northwest Gulf of Mexico: Geol. Soc. America Bull., v. 66 , no. 2, p. 203-228.

Gussow, W. C., 1968, Salt diapirism-Importance of temperature, and energy source of emplacement, in Braunstein, Jules, and O'Brien, G. D., eds., Diapirism and diapirs-A symposium: Am. Assoc. Petroleum Geologists Mem. 8, p. 16-52.

Halbouty, M. T., 1967, Salt domes-Gulf region, United States and Mexico: Houston, Tex., Gulf Pub. Co., $425 \mathrm{p}$.

Harbison, R. N., 1967, De Soto Canyon reveals salt trends: Oil and Gas Jour., v. 65, no. 8, p. 124-128.

1968, Geology of the De Soto Canyon: Jour. Geophys. Research, v. 73 , no. 16 , p. 5175-5185.

Hardin, F. R., and Hardin, G. C., Jr., 1961, Contemporaneous normal faults of Gulf Coast and their relation to flexures: Am. Assoc. Petroleum Geologists Bull., v. 45, no. 2, p. 238-248.

Hardin, G. C., Jr., 1962, Notes on Cenozoic sedimentation in the Gulf Coast geosyncline, U.S.A., in Geology of the Gulf Coast and central Texas and guidebook of excursions, Geol. Soc. America, 1962 Ann. Mtg.: Houston, Tex., Houston Geol. Soc., p. 1-15.

Huang, Ter-Chien, and Goodell, H. G., 1970, Sediments and sedimentary processes of eastern Mississippi cone, Gulf of Mexico: Am. Assoc. Petroleum Geologists Bull., v. 54, no. 11, p. 2070-2100.

Hurley, R. J., 1964, Bathymetry of the Straits of Florida and the Bahama Islands-Part 3, Southern Straits of Florida: Bull. Marine Sci. Gulf and Caribbean, v. 14, no. 3, p. 373-380.

Jones, B. R., Antoine, J. W., and Bryant, W. R., 1967, A hypothesis concerning the origin and development of salt structures in the Gulf of Mexico sedimentary basin: Gulf Coast Assoc. Geol. Socs. Trans., v. 17, p. 211-216.

Jordan, G. F., 1951, Continental slope off Apalachicola River, Florida: Am. Assoc. Petroleum Geologists Bull., v. 35, no. 9, p. p. $1978-1993$.

- 1954, Large sink holes in Straits of Florida: Am. Assoc. Petroleum Geologists Bull., v. 38, no. 8, p. 18101817.

Jordan, G. F., Malloy, R. J., and Kofoed, J. W., 1964, Bathymetry and geology of Pourtales Terrace, Florida: Marine Geology, v. 1, no. 3, p. 259-287.

Jordan, G. F., and Stewart, H. B., Jr., 1959, Continental slope off southwest Florida: Am. Assoc. Petroleum Geologists Bull., v. 43, no. 5, p. 974-991.

1961, Submarine topography of the western Straits of Florida: Geol. Soc. America Bull., v. 72, no. 7, p. 10511058.

Khudoley, K. M., 1967, Principal features of Cuban geology: Am. Assoc. Petroleum Geologists Bull., v. 51, no. 5, p. 668-677.

King, P. B., comp., 1969, Tectonic map of North America: Washington, D.C., U.S. Geol. Survey, scale 1:5,000,000.

Kirkland, D. W., and Gerhard, J. E., 1971, Jurassic salt, central Gulf of Mexico, and its temporal relation to circum-Gulf evaporites: Am. Assoc. Petroleum Geologists Bull., v. 55, no. 5, p. 680-686.
Lehner, Peter, 1969, Salt tectonics and Pleistocene stratigraphy on continental slope of northern Gulf of Mexico: Am. Assoc. Petroleum Geologists Bull., v. 53, no. 12, p. 2431-2479.

Logan, B. W., Harding, J. L., Ahr, W. M., Williams, J. D., and Snead, R. G., 1969, Carbonate sediments and reefs, Yucatan shelf, Mexico: Am. Assoc. Petroleum Geologists Mem. 11, p. 1-198.

Malloy, R. J. and Hurley, R. J., 1970, Geomorphology and geologic structure; Straits of Florida: Geol. Soc. America Bull., v. 81, no. 7, p. 1947-1972.

Marsh, O. T., 1967, Evidence for deep salt deposits in western Florida panhandle: Am. Assoc. Petroleum Geologists Bull., v. 51, no. 2, p. 212-222.

Martin, R. G., Jr., 1972, Structural features of the continental margin, northeastern Gulf of Mexico: U.S. Geol. Survey Prof. Paper 800-B, p. B1-B8.

Meyerhoff, A. A., 1967, Future hydrocarbon provinces of Gulf of Mexico-Caribbean region: Gulf Coast Assoc. Geol. Socs. Trans., v. 17, p. 217-260.

Miser, H. D., 1921, Llanoria, the Paleozoic land area in Louisiana and eastern Texas: Am. Jour. Sci., 5th ser., v. 2, p. 61-89.

Moore, D. G., and Curray, J. R., 1963, Structural framework of the continental terrace, northwest Gulf of Mexico: Jour. Geophys. Research, v. 68, no. 6, p. 17251747.

Moore, G. W., and others, 1971, U.S.G.S.-I.D.O.E., Leg 1: Bahia de Campeche: Geotimes, v. 16, no. 11, p. 16-17.

Murray, G. E., 1961, Geology of the Atlantic and Gulf coastal province of North America: New York, Harper \& Bros., $692 \mathrm{p}$.

1966, Salt structures of Gulf of Mexico basin-A review: Am. Assoc. Petroleum Geologists Bull., v. 50, no. 3, pt. 1, p. $439-478$.

1968, Salt structures of Gulf of Mexico basin-A review, in Braunstein, Jules, and O'Brien, G. D., eds., Diapirism and diapirs-A symposium: Am. Assoc. Petroleum Geologists Mem. 8, p. 99-121.

Nowlin, W. D., Jr., Harding, J. L., and Amstutz, D. E., 1965. A reconnaissance study of the Sigsbee Knolls of the Gulf of Mexico: Jour. Geophys. Research, v. 70, no. 6, p. 1339-1347.

Ocamb, R. D., 1961, Growth faults of south Louisiana: Gulf Coast Assoc. Geol. Socs., Trans., v. 11, p. 139-175.

Oglesby, W. R., 1965, Folio of south Florida basin-A preliminary study: Florida Geol. Survey Map Ser. 19, 3 p.

Pressler, E. D., 1947, Geology and occurrence of oil in Florida: Am. Assoc. Petroleum Geologists Bull., v. 31, no. 10, p. 1851-1862.

Pyle, T. E., Antoine, J. W., Fahlquist, D. A., and Bryant, W. R., 1969, Magnetic anomalies in Straits of Florida: Am. Assoc. Petroleum Geologists Bull., v. 53, no. 12, p. 25012505.

Pyle, T. E., Bryant, W. R., and Antoine, J. W., 1968, Geophysical studies of the south Florida continental margin and western Straits of Florida [abs.]: Gulf Coast Assoc. Geol. Socs. Trans., v. 18, p. 50.

Sánchez Mejorada, S. H., and Lopez Ramos, Ernesto, compilers, 1968, Carta geológica de la República Mexicana: [Mexico, D.F.] Comite de la Carta Geológica de Mexico scale $1: 2,000,000$, text.

Schmalz, R. F., 1969, Deep-water evaporite deposition-A 
genetic model: Am. Assoc. Petroleum Geologists Bull., v. 53 , no. 4 , p. $798-823$.

Schuchert, C., 1935, Historical geology of the AntilleanCaribbean region, or the lands bordering the Gulf of Mexico and the Caribbean Sea: New York, John Wiley \& Sons, $811 \mathrm{p}$.

Selig, Franz, and Wermund, E. G., 1966, Families of salt domes in the Gulf Coastal province: Geophysics, v. 31, no. 4 , p. 726-740.

Shepard, F. P., 1955, Delta-front valleys bordering the Mississippi distributaries: Geol. Soc. America Bull., v. 66 , no. 12 , pt. 1 , p. $1489-1498$.

1963, Submarine geology: 2d ed., New York, Harper and Row, $557 \mathrm{p}$.

Uchupi, Elazar, 1966, Shallow structure of the Straits of Florida: Science, v. 153, no. 3735, p. 529-531.

1967, Bathymetry of the Gulf of Mexico: Gulf Coast Assoc. Geol. Socs. Trans., v. 17, p. 161-172.

Uchupi, Elazar, and Emery, K. O., 1968, Structure of continental margin off Gulf Coast of United States: Am. Assoc. Petroleum Geologists Bull., v. 52, no. 7, p. 11621193.
Vedder, J. G., and others, 1971, U.S.G.S.-I.D.O.E.: Leg 2; preliminary report: Geotimes, v. 16, no. 12, p. 10-12.

Viniegra O., Francisco, 1971, Age and evolution of salt basins of southeastern Mexico: Am. Assoc. Petroleum Geologists Bull., v. 55, no. 3, p. 478-494.

Walker, J. R., and Massingill, J. V., 1970, Slump features on the Mississippi fan, northeastern Gulf of Mexico: Geol. Soc. America Bull., v. 81, no. 10, p. 3101-3108.

Weaver, Paul, 1950, Variations in history of continental shelves: Am. Assoc. Petroleum Geologists Bull., v. 34, no. 3, p. 351-360.

Wilhelm, Oscar, and Ewing, Maurice, 1972, Geology and history of the Gulf of Mexico: Geol. Soc. America Bull., v. 83 , no. 3 , p. $575-600$.

Worzel, J. L., and Bryant, W. R., 1970, Deep Sea Drilling Project: Leg 10; preliminary report: Geotimes, v. 15, no. 6, p. 11-13.

Worzel, J. L., Leyden, Robert, and Ewing, Maurice, 1968, Newly discovered diapirs in Gulf of Mexico: Am. Assoc. Petroleum Geologists Bull., v. 52, no. 7, p. 1194-1203.

Yarborough, Hunter, 1968, Geologic history of the Gulf basin [abs.] : Geophysics, v. 33, no. 6, p. 1045-1046. 

SELECTED SEISMIC REFLECTION PROFILES SHOWING GEOLOGIC STRUCTURES TYPICAL OF GULF OF MEXICO

Figures 8-34 

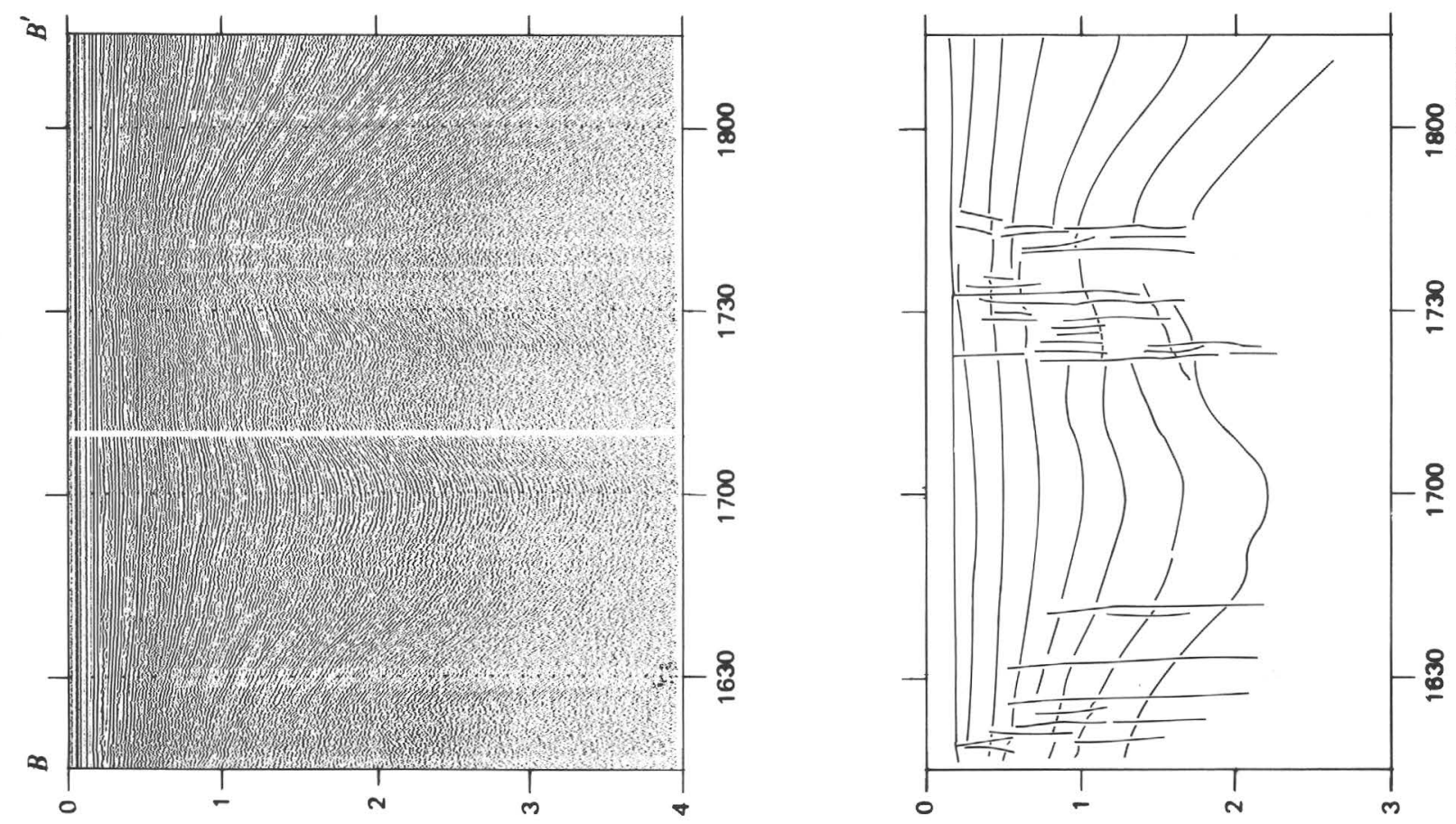

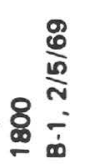
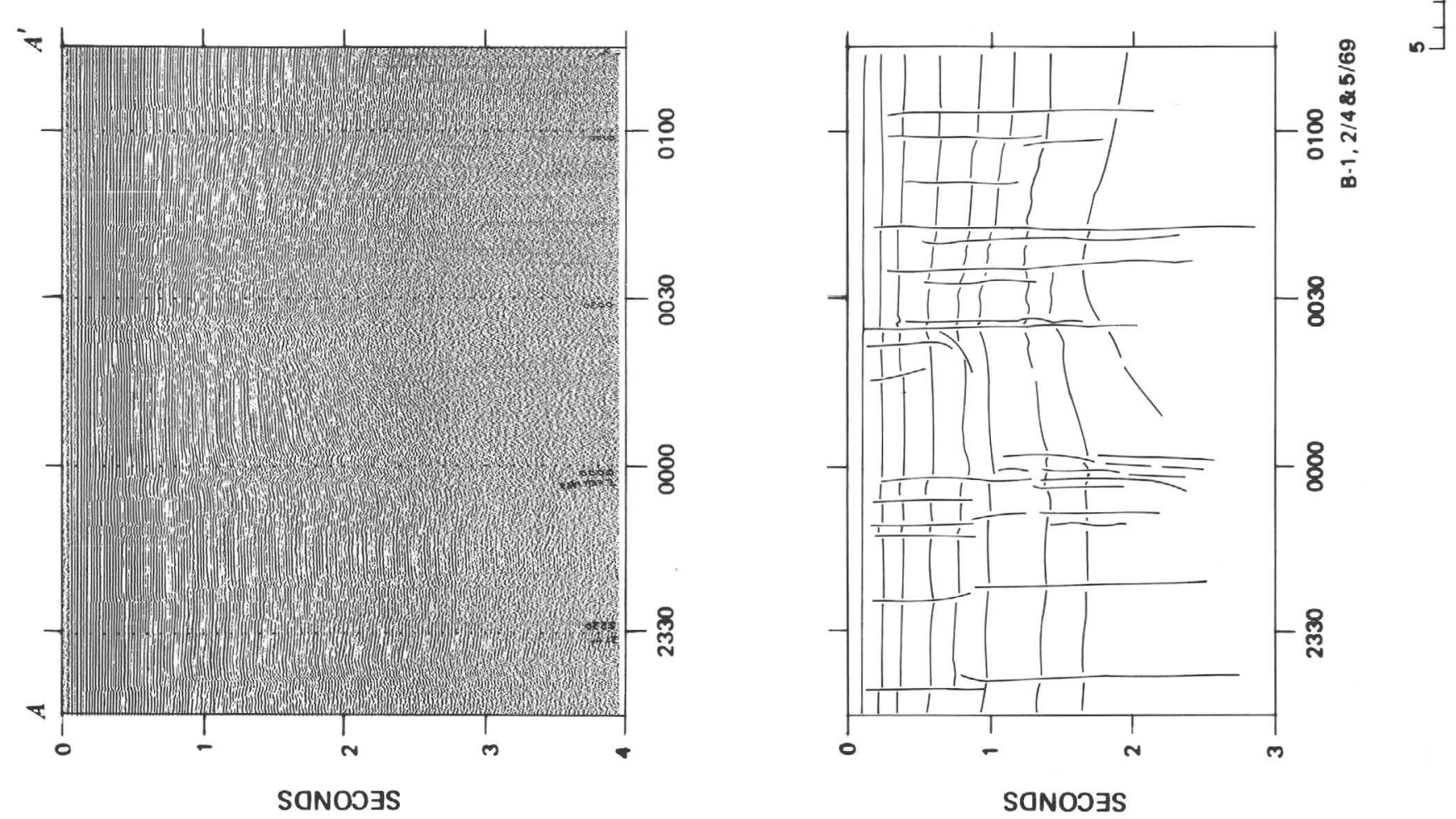
FIGURE 8.-Seismic-reflection profiles, outer continental shelf, Texas and Louisiana. Locations shown in figure 10. Profiles in figures 8 and 9 illustrate the degree to which shelf sediments are deformed by salt tectonics and the transition of structural character in the outer shelf from west to east. Profile $A-A^{\prime}, 80 \mathrm{~km}$ east of Port Aransas, Tex., shows arching and dislocation of beds caused by steeply dipping normal faults. Although of small displacement, some of these faults extend from the shelf floor to depths of more than $2 \mathrm{~km}$; others terminate at various levels beneath the sea floor. The area of broad arching centered near $0030 \mathrm{hr}$ affects horizons as shallow as 0.3 sec (about $280 \mathrm{~m}$ ) below the shelf surface. At a depth of about $2 \mathrm{~km}$, the anticlinal structure is more than $9 \mathrm{~km}$ wide, but to the effective depth of acoustic resolution, no evidence of a diapiric salt core is seen, suggesting that if the structure reflects a salt dome, the core must be deeper than $4 \mathrm{~km}$. Profile $B-B^{\prime}$, about $220 \mathrm{~km}$ east of $A-A^{\prime}$ shows a markedly different structural character. The width of the anticlinal feature centered at $1740 \mathrm{hr}$ is not appreciably less at a depth of $2 \mathrm{~km}$ than that in $A-A^{\prime}$; the entire structure is better defined, having a narrow crest and flanking synclines. The arching of beds over the crest extends much higher in the sediment section, and pronounced unconformities approach within a few meters of the shelf surface at $1740 \mathrm{hr}$ as well as over the second anticline centered near $1615 \mathrm{hr}$. Fault planes are very steep and offset is relatively slight, but rather than being dispersed, faults are tightly clustered over structural crests, especially around $1740 \mathrm{hr}$. 

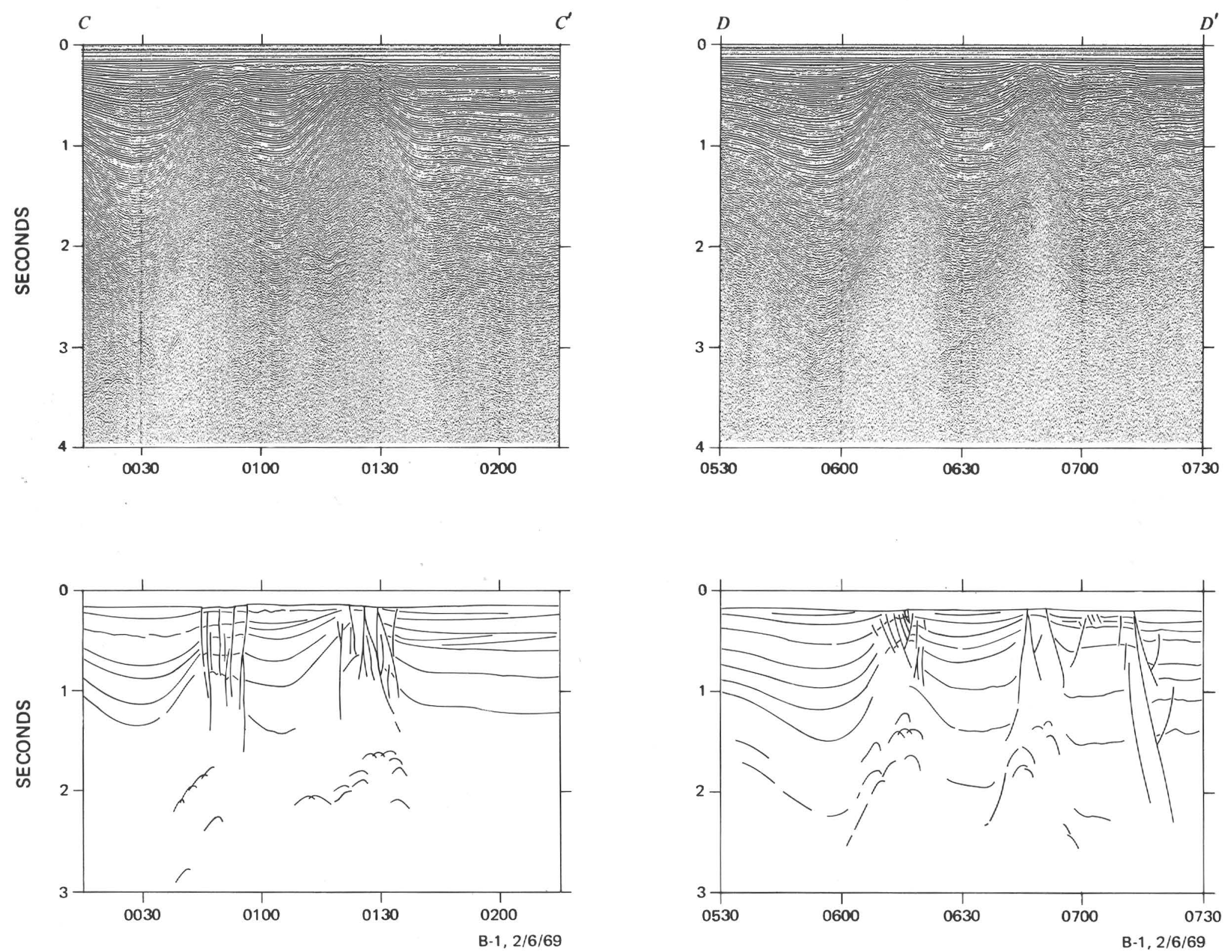
Figure 9.-Seismic-reflection profiles, outer continental shelf, Texas and Louisiana; series continued from figure 8. Locations shown on figure 10. Profile $C-C^{\prime}$ is $110 \mathrm{~km}$ east of $B-B^{\prime}$ (fig. 8) and shows more sharply defined structures. Uplifted areas over the domes at 0045 and $0125 \mathrm{hr}$ are still about $9 \mathrm{~km}$ wide at a depth of $2 \mathrm{~km}$, but apparent dips off their flanks are steeper $\left(12^{\circ}\right.$ as compared to $10^{\circ}$ in $\left.B-B^{\prime}\right)$. Faulting is strongly concentrated over the crests of uplifted areas and more clearly shows the geometry of the collapse structures which are typical of many salt domes (Currie, 1956). The sea floor is marked by fault scarps and has been strongly depressed by graben development suggesting salt-dome growth has been more vigorous or sedimentation less active than along the shelf edge farther west. Top of the salt probably is at a depth of a little more than $1.5 \mathrm{sec}$ in the dome at $0125 \mathrm{hr}$ and perhaps between 1.5 and 2.0 sec in the fracture at 0045 hr. Profile $D-D^{\prime}$, about $55 \mathrm{~km}$ east of $C-C^{\prime}$, shows salt only a little less than 1 sec below the surface of the shelf in the domes at 0615 and $0645 \mathrm{hr}$. A complex system of collapse faulting has developed over the dome at $0615 \mathrm{hr}$, but over the other dome the fault pattern is much simpler. Stratification in the syncline between the domes indicates relatively heavy sedimentation because of the proximity of the Mississippi River Delta. Near $0715 \mathrm{hr}$, a zone of normal faulting of rather large displacement (approximately $285 \mathrm{~m}$ at a depth of only $150 \mathrm{~m}$ below the sea floor) intersects the shelf surface; this faulting is not directly connected with the dome at $0645 \mathrm{hr}$. Thickening and multiplication of beds on the down-dropped block is further evidence of the rapid sediment influx occurring in this area. A high-resolution profile of part of $D-D^{\prime}$ is shown in figure 10 . 


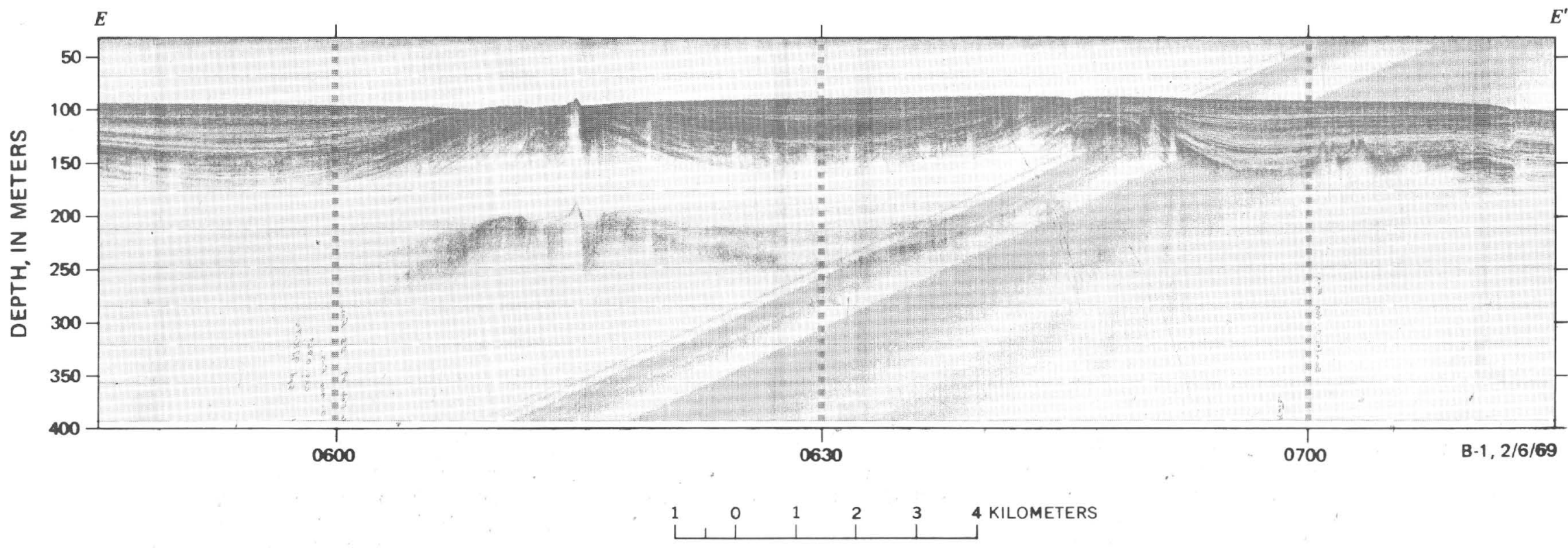

$E^{\prime}$

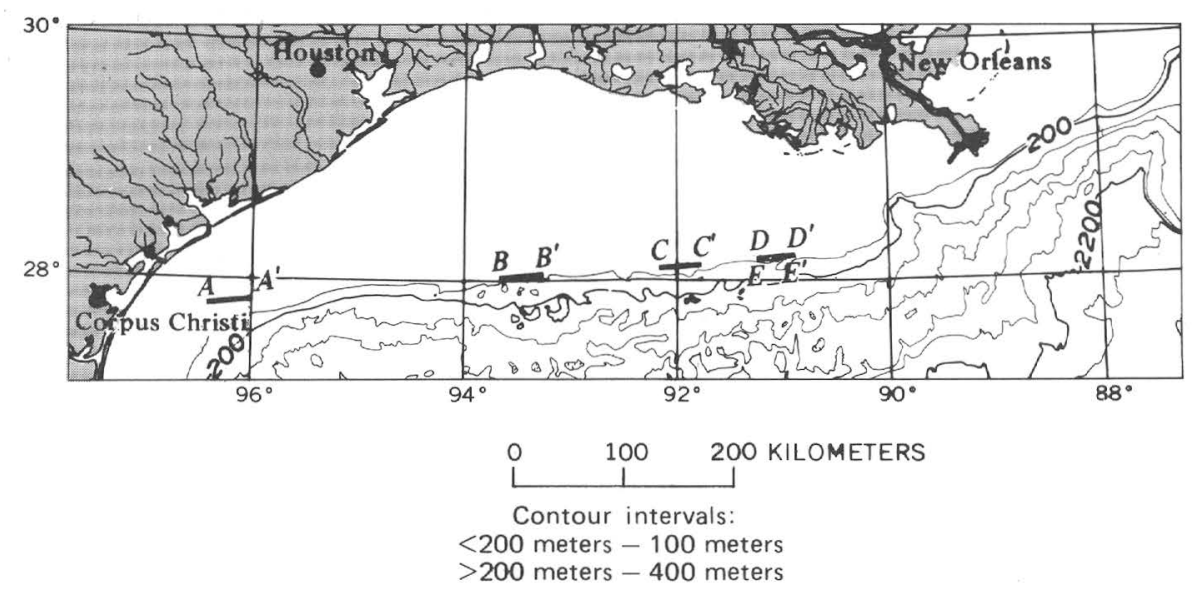


FIGURE 10.-High-resolution seismic profile $E-E^{\prime}$, corresponding to a portion of $D-D^{\prime}$ (fig. 9), outer continental shelf, Louisiana, and location diagram for figures 8,9 , and 10 . The profile gives a detailed view of the upper $75-80 \mathrm{~m}$ (about $0.1 \mathrm{sec}$ ) of subbottom shown in $D-D^{\prime}$; the profiles were recorded simultaneously, and the location times are identical. Older sediments are raised to the surface over the crests of salt diapirs located at 0615 and 0645 hr. Erosion of these uplifted beds and filling of the adjacent rim synclines has almost smoothed the sea floor. The nature of the small spine on the crest of the structure on the left is not known, but its relationship to the upwarped beds suggests that it may be a welt of mobile material, such as clay, extruded along a tension fault in the arched beds. The surface expression of the fault shown in $D-D^{\prime}$ at $0715 \mathrm{hr}$ can be seen near the right edge of this profile. 

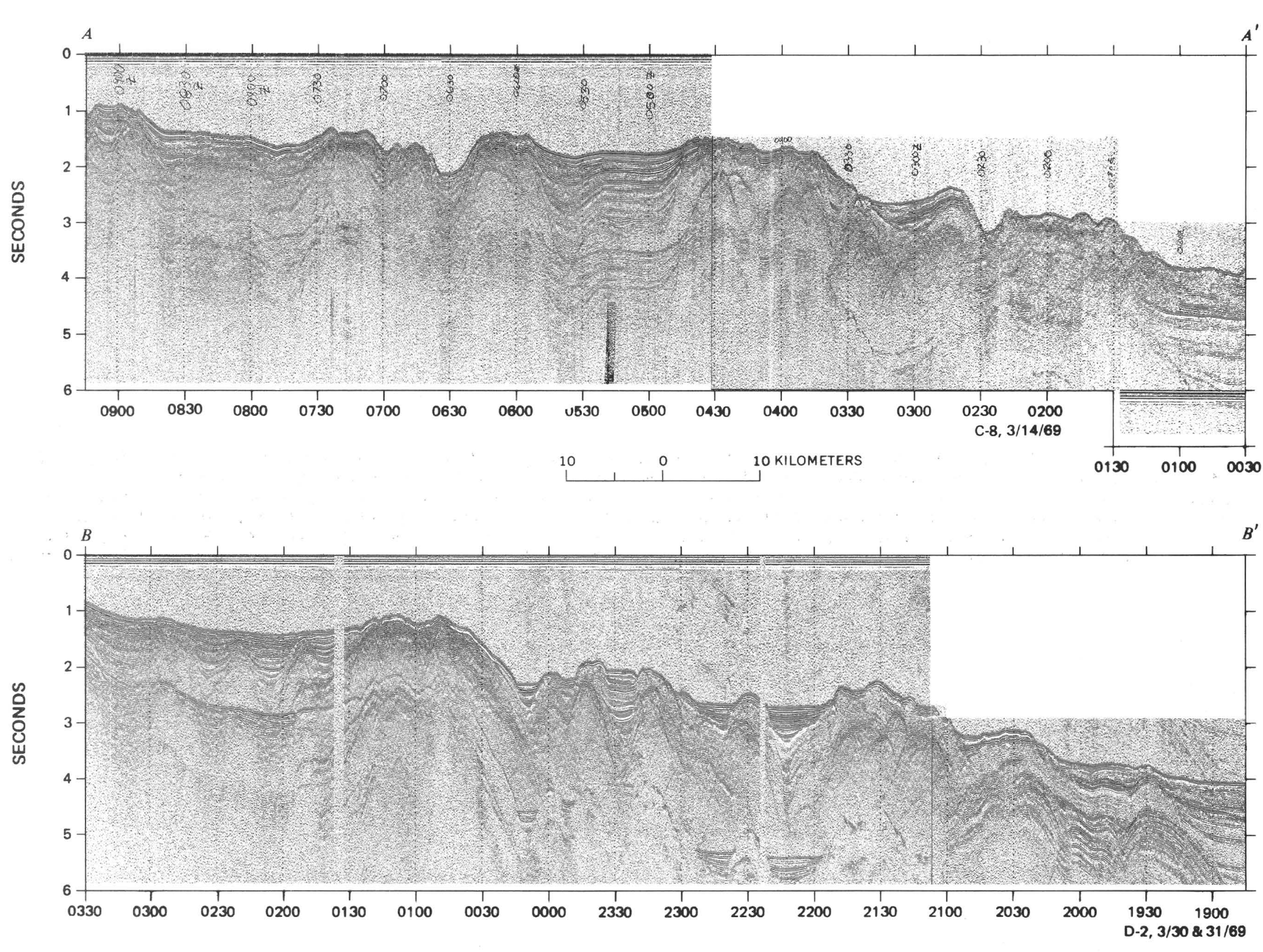


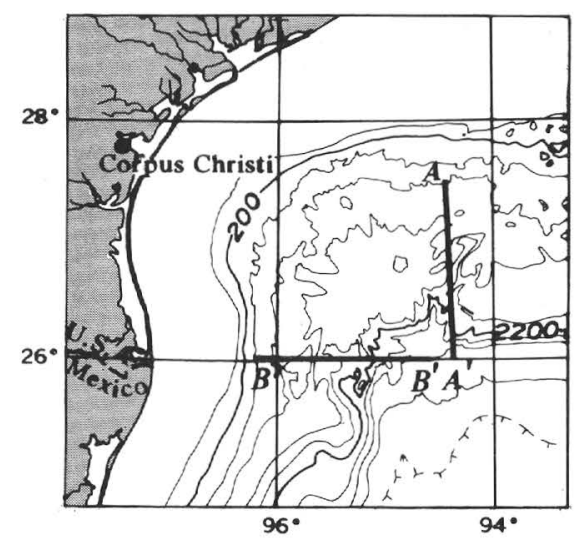

$96^{\circ}$

\section{0 \\ 100 \\ Contour intervals: \\ $<200$ meters -100 meters}

200 KILOMETERS

$>200$ meters -400 meters

FIGURE 11.-Seismic-reflection profiles, continental slope, northwest Gulf of Mexico. Profile $A-A^{\prime}$ illustrates the characteristic structure of the continental slope off Texas and Louisiana. Division of upper and lower slope occurs at about $0445 \mathrm{hr}$. The upper slope is typified by individual diapiric structures and thick sediment sequences separating them; upper surface is hummocky and has a relatively low average gradient. The lower slope, in contrast, has a much rougher upper surface with a steeper gradient; basins are shallow, small, and are less commonly filled with sediment. The salt underlying the lower slope appears to be an almost solid mass, or massif, rather than individual diapirs. Termed the Sigsbee salt front, this massif and the uplifted continental-rise sediments form the Sigsbee Escarpment (0115-0130 hr). Amery (1969) reported that at one point, salt has been extruded a distance of $10 \mathrm{~km}$ over flat-lying continental-rise beds south of the scarp, on the basis of reflections similar to those at $0130-0230 \mathrm{hr}, 1.0-2.0$ sec below the sea floor. Profile $B-B^{\prime}$ crosses the continental slope east of the mouth of the Rio Grande. Individual domes (0150-0220 hr) which characterize the upper slope (west from $0130 \mathrm{hr}$ ) are less well developed than off Texas and Louisiana, but the massive salt body of the lower slope is entirely analogous to its counterpart in $A-A^{\prime}$. Although covered by thicker sediments east of $0015 \mathrm{hr}$, the salt mass (Rio Grande salt front) has a comparable width to the Sigsbee salt front. Basins on its surface are restricted and relatively shallow, and continental-rise sediments have been incorporated into the escarpment (1900$2100 \mathrm{hr}$ ). Uplift of continental-rise sediments to form the topographic scarp is more chanacteristic of the lower slope regions of the Rio Grande salt front than of the Sigsbee Escarpment. Although salt has elevated and penetrated a thick sediment column, final smoothing of the sea-floor topography on the upper slope is the result of rapid ponding of sediment and cessation of diapiric growth. The hummocky topography in $A-A^{\prime}$, on the other hand, has been created by continued growth of diapirs and a limited sediment influx. 

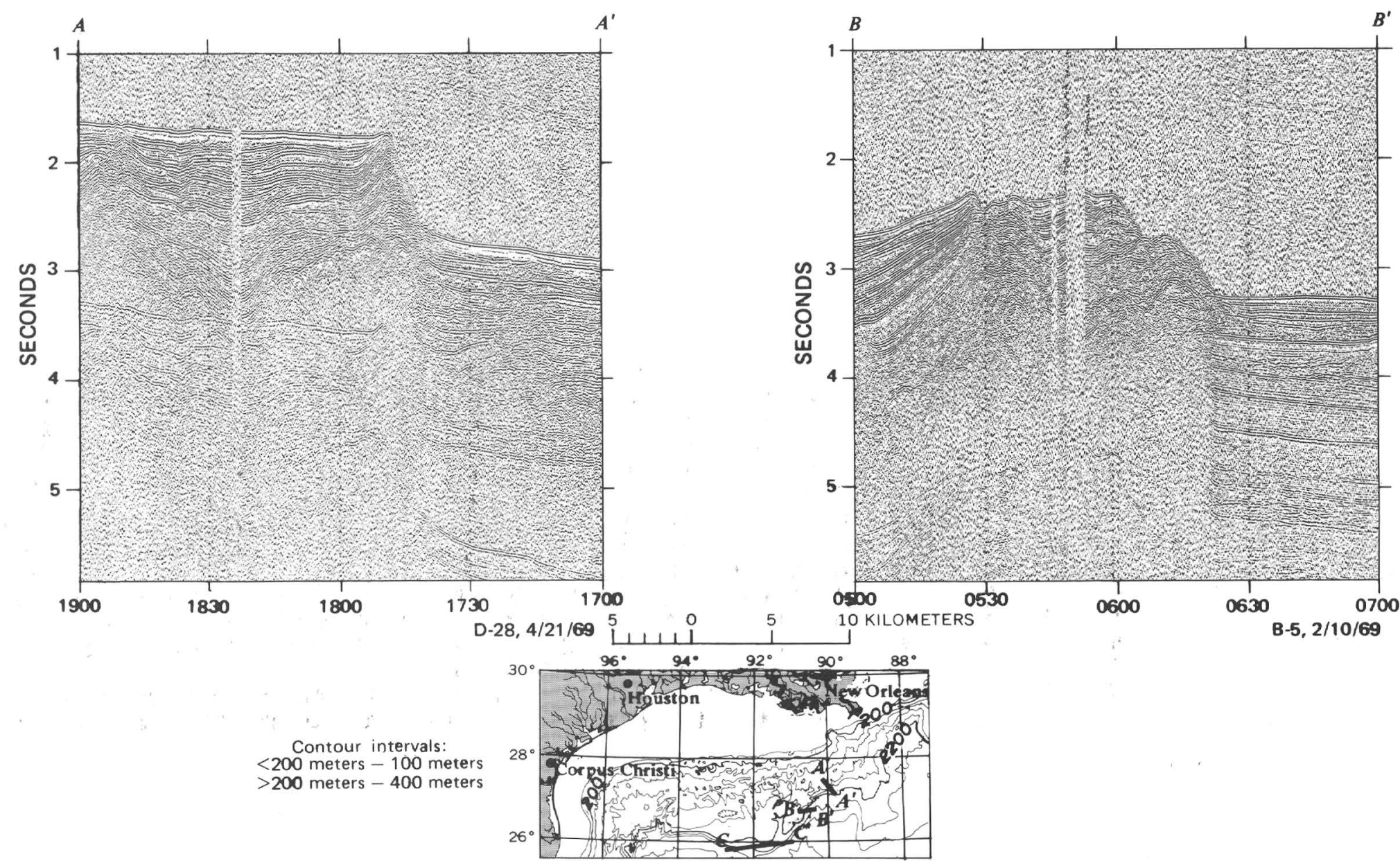

ㄴ.1

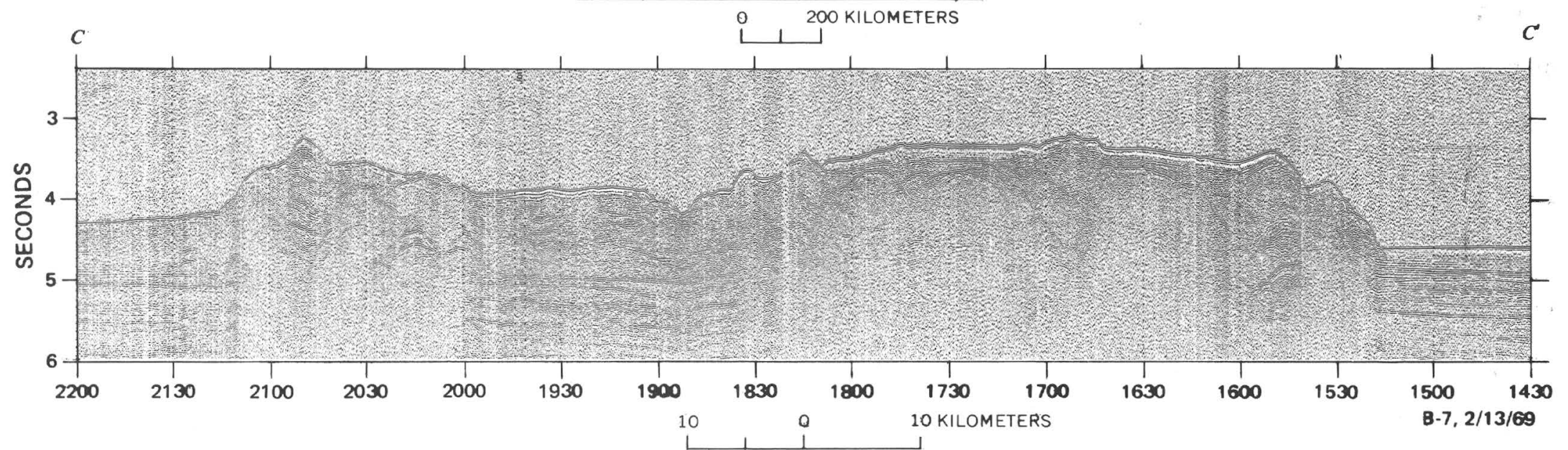




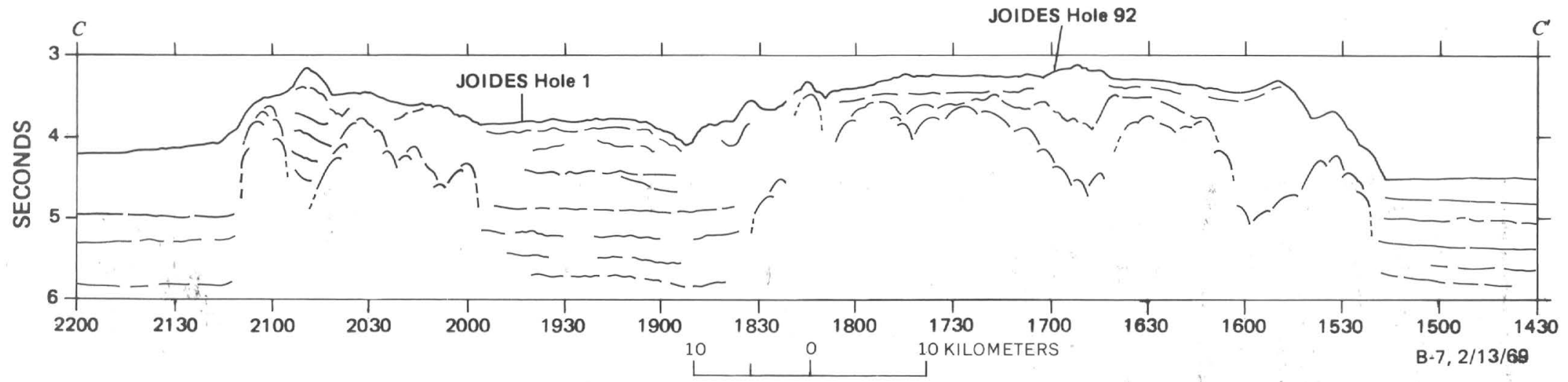

FIGURE 12.-Seismic-reflection profiles, Sigsbee Escarpment. Profile $A-A^{\prime}$ was made near the easternmost end of the escarpment where it has a relief of $675 \mathrm{~m}$ and an apparent slope of about $17^{\circ}$. The probable salt top appears beneath the scarp at about 2.8 sec. The conformity with which the sedimentary beds overlie the rough salt top suggests that they are continental-rise deposits which have been warped and elevated by rising salt. The uppermost 100-200 m of flat-lying sediment which fills the uppermost irregular surface has been deposited since salt movement ceased and probably reflects the proximity of the region to the Mississippi River mouth. An apparent abrupt termination of continental-rise layers at a vertical plane beneath the scarp face is characteristic of most crossings of the Sigsbee Escarpment. It does not necessarily imply that a wall of salt extends downward to the base of the profile, however, as sedimentary beds which may occur beneath a relatively thin layer of salt would be hidden by the resulting velocity inversion. Profile $B-B^{\prime}$ is an east-facing scarp crossing showing approximately the same amount of relief as in $A-A^{\prime}$, but with a step on the scarp face. The probable salt reflector below the scarp is at about 3.2 sec. It is covered by a lower unit consisting of 0.4-0.6 sec of unbedded material and an upper unit of 0.5-1.0 sec of layered sediments. The unstructured lower unit forms a peak at 0535 $\mathrm{hr}$ which appears to have pierced the overlying sediments and is exposed at the sea floor; it is also exposed on the scarp face where it forms the lower step. The apparent conformity of this unit to the salt beneath suggests that it may be caprock material, or a basal clay layer. The pronounced layering of the upper unit, as in $A-A^{\prime}$, suggests that it may be an elevated section of continental-rise deposits. Profile $C-C^{\prime}$ is an east-west crossing of the escarpment which appears at $1520 \mathrm{hr}$ on the east, and $2110 \mathrm{hr}$ on the west. In the line drawing, the profile is interpreted as showing two salt lobes separated by a sediment-filled reentrant in the escarpment. Near 1730 hr, Amery (1969) described a wedge of salt extending $10 \mathrm{~km}$ seaward over flat-lying continental-rise beds. Faint reflections near 4.5 sec subsea in $C-C^{\prime}$ near 1730 hr are probably those referred to; no other example can be seen in these records. The first hole drilled by JOIDES was put down near 1945 hr on $C-C^{\prime}$, and penetrated $619 \mathrm{~m}$ of Pleistocene mudstone rich in detrital carbonate deposits and with a constant background of Cretaceous planktonic Foraminifera (Ewing and others, 1969). Data pertaining to hole 92 (JOIDES leg 10) have not yet been reported. The rumpled nature of the uppermost beds suggests rapid fill largely by downslope movement of slumped sediment and contrasts with the more evenly bedded sediments in the lower part of the section which appear to be continuous with the continental-rise section on either end of the profile. A submarine channel at 1850 hr possibly has acted as a conduit for recent turbidity flows; older filled channels are seen elsewhere in the section. At 2050 hr, a block of sediment, apparently uplifted by the salt, is shown. The sequence of bedding in this block suggests the possibility that the sediment may have been originally a part of the bedded lower sequence of the continental rise present on both flanks of the salt lobe. (See fig. 13 for detail.) 

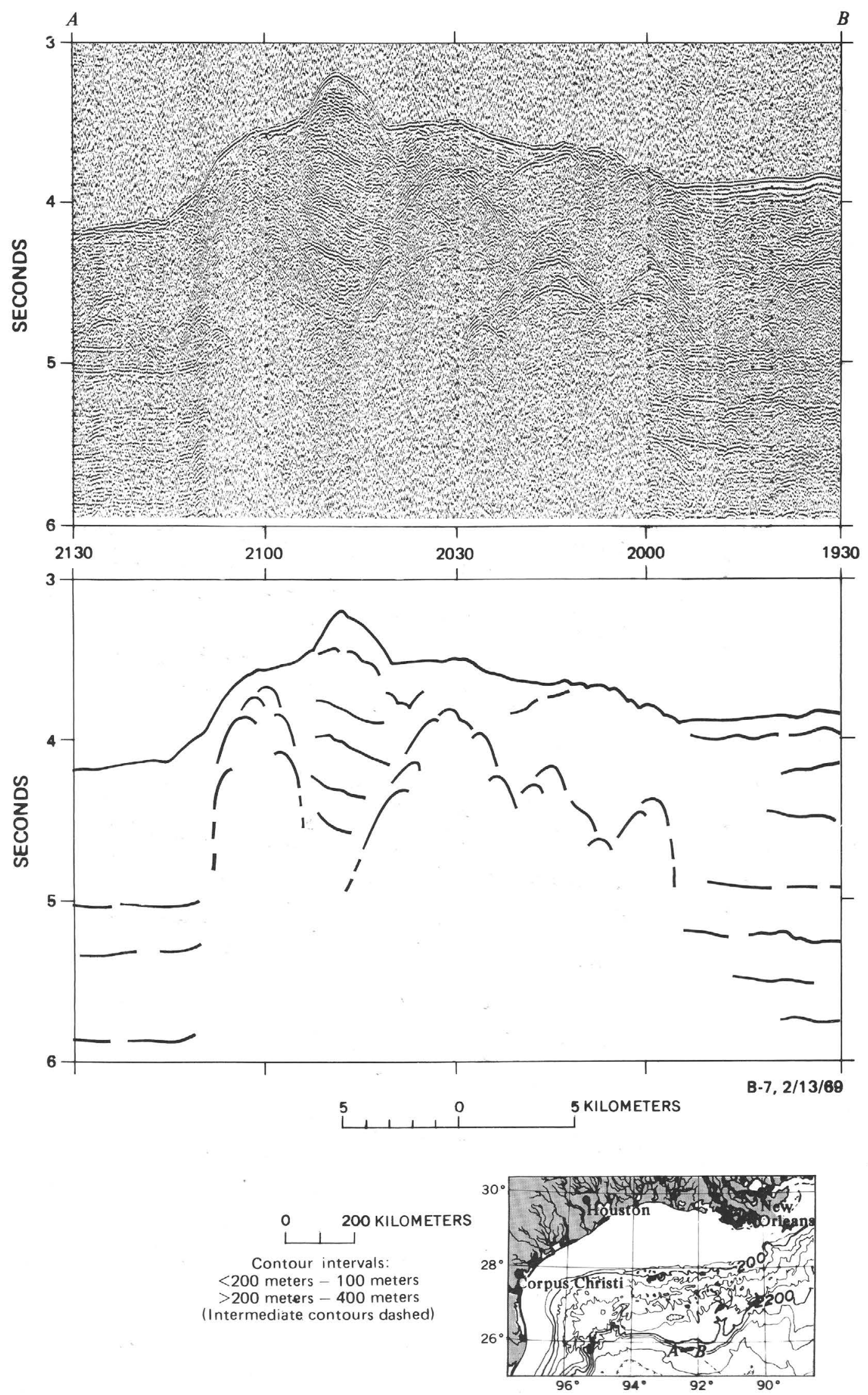
Figure 13.-Seismic-reflection profile, Sigsbee Escarpment. This illustration is an enlarged view of a segment of $C-C^{\prime}$, figure 12. In the area between 2000 and $2110 \mathrm{hr}$, a salt body has intruded the thick sequence of continental-rise sediments to produce a south-facing salient, or lobe, in the escarpment. The salt mass is nearly $20 \mathrm{~km}$ wide at a subsea depth of $5.0 \mathrm{sec}$; two prominent peaks rise above the main body of salt to within a few hundred meters of the sea floor. Intrusion by the diapiric mass has displaced a discrete block (2040-2050 hr) of layered material more than 0.8 sec above its original position. The sequence of reflectors within the block suggests correlation with the well-defined stratified section that appears below $4.9 \mathrm{sec}$ subsea on either side of the salt body. 

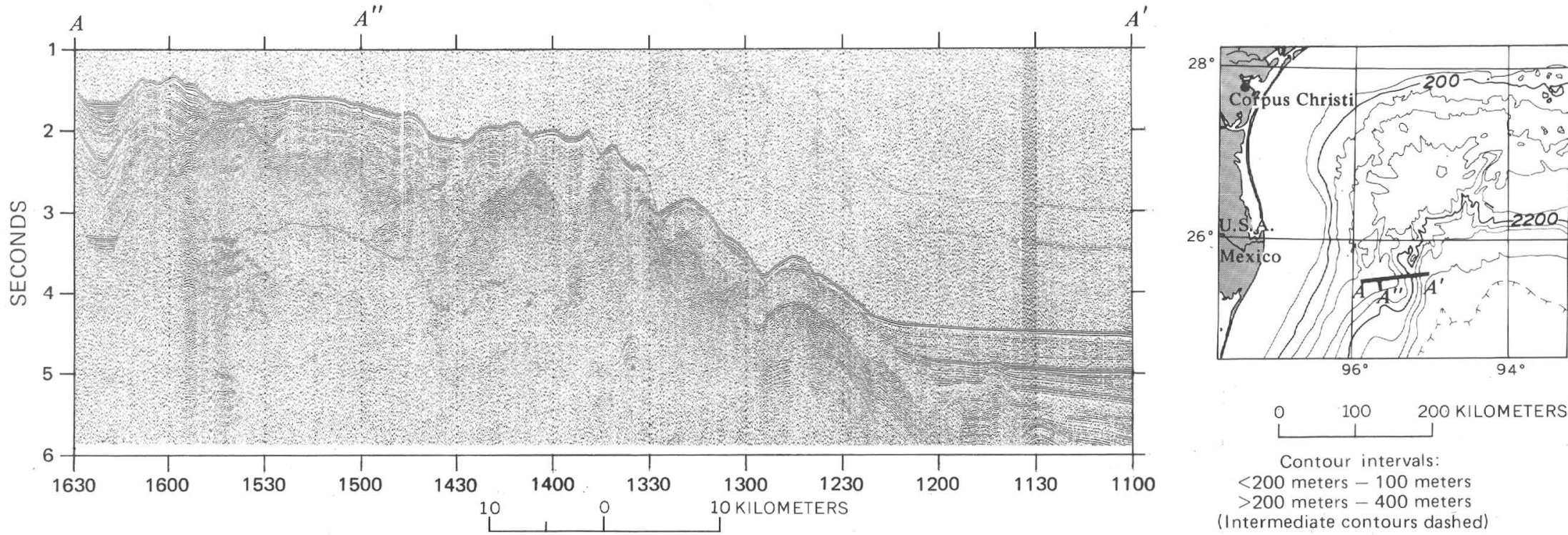

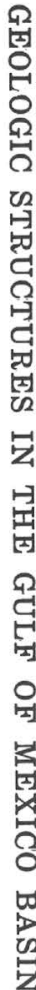

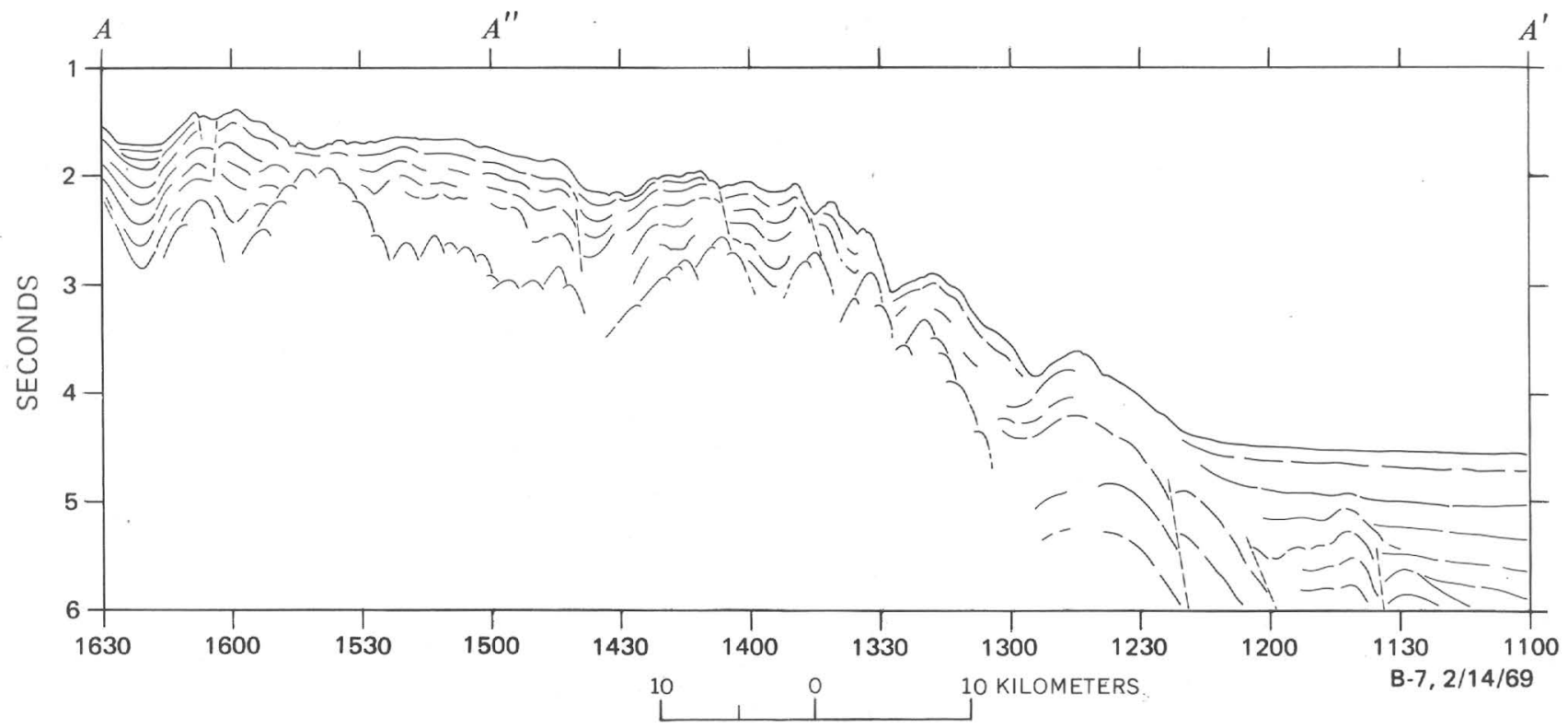




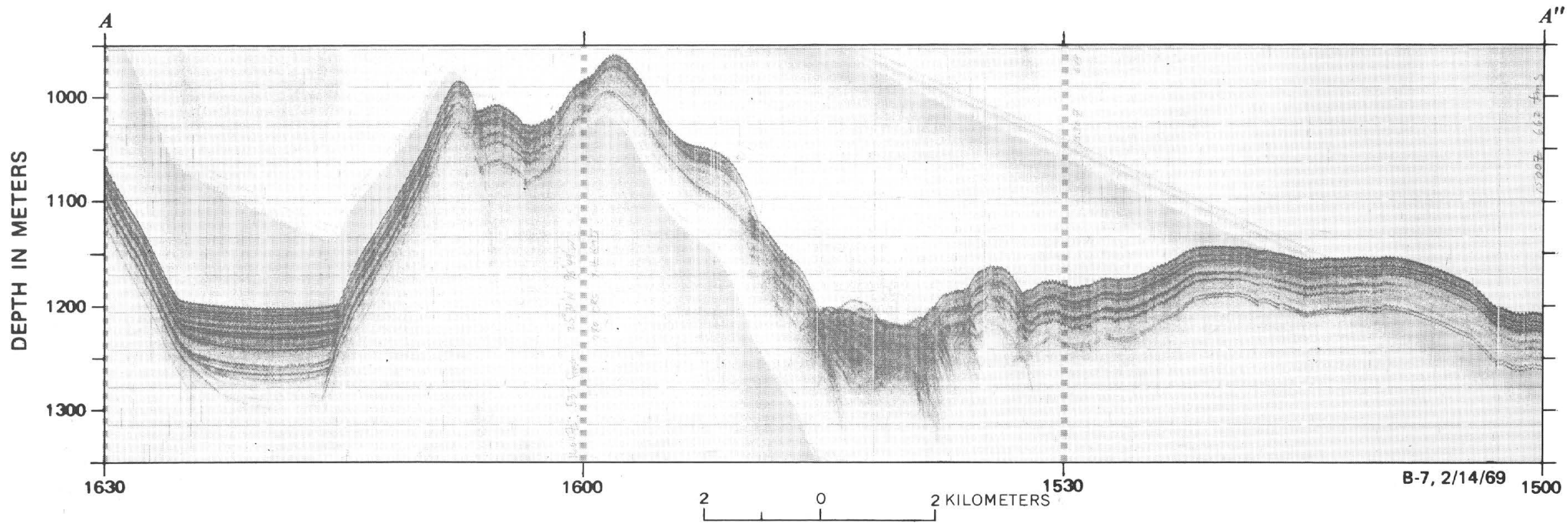

FIGURE 14.-Seismic-reflection profiles, lower continental slope southeast of the Rio Grande. Profile $A-A^{\prime}$ shows characteristic lower slope salt massif (Rio Grande salt front) covered by a relatively thin but continuous sediment blanket which contrasts with the thin, discontinuous sediment cover over the Sigsbee salt front (fig. 12). The toe of the escarpment consists of folded continental-rise sediments; seismic penetration is not sufficient to reveal salt core (if any) beneath these folds. Older continental-rise sediments near $1130 \mathrm{hr}$ have been uplifted, folded, and faulted, then buried by more than $1 \mathrm{~km}$ of turbidite and pelagic deposits. The almost transparent zone of sediments over the salt on the lower slope passes seaward under younger continental-rise sediment. Although the small pocket at $1620 \mathrm{hr}$ contains about $300 \mathrm{~m}$ of fill, little or no sediment seems to have accumulated in the irregularities of the lower slope, indicating a low rate of basinward transport in this region. A segment of high-resolution profile corresponding to the western end of $A-A^{\prime}$ is shown here as $A-A^{\prime \prime}$. The sediment pocket at $1620 \mathrm{hr}$ is shown in greater detail, as are other features of the upper 50-60 m of lower slope deposits. The flanks of the prominence at $1600 \mathrm{hr}$ which rises $250 \mathrm{~m}$ above the adjacent area slope downward at about $6^{\urcorner}-7^{\circ}$. Although the area of thick jumbled bedding near $1540 \mathrm{hr}$ may be slump material off the east flank, sediments on the west flank appear to be stable at that inclination. 

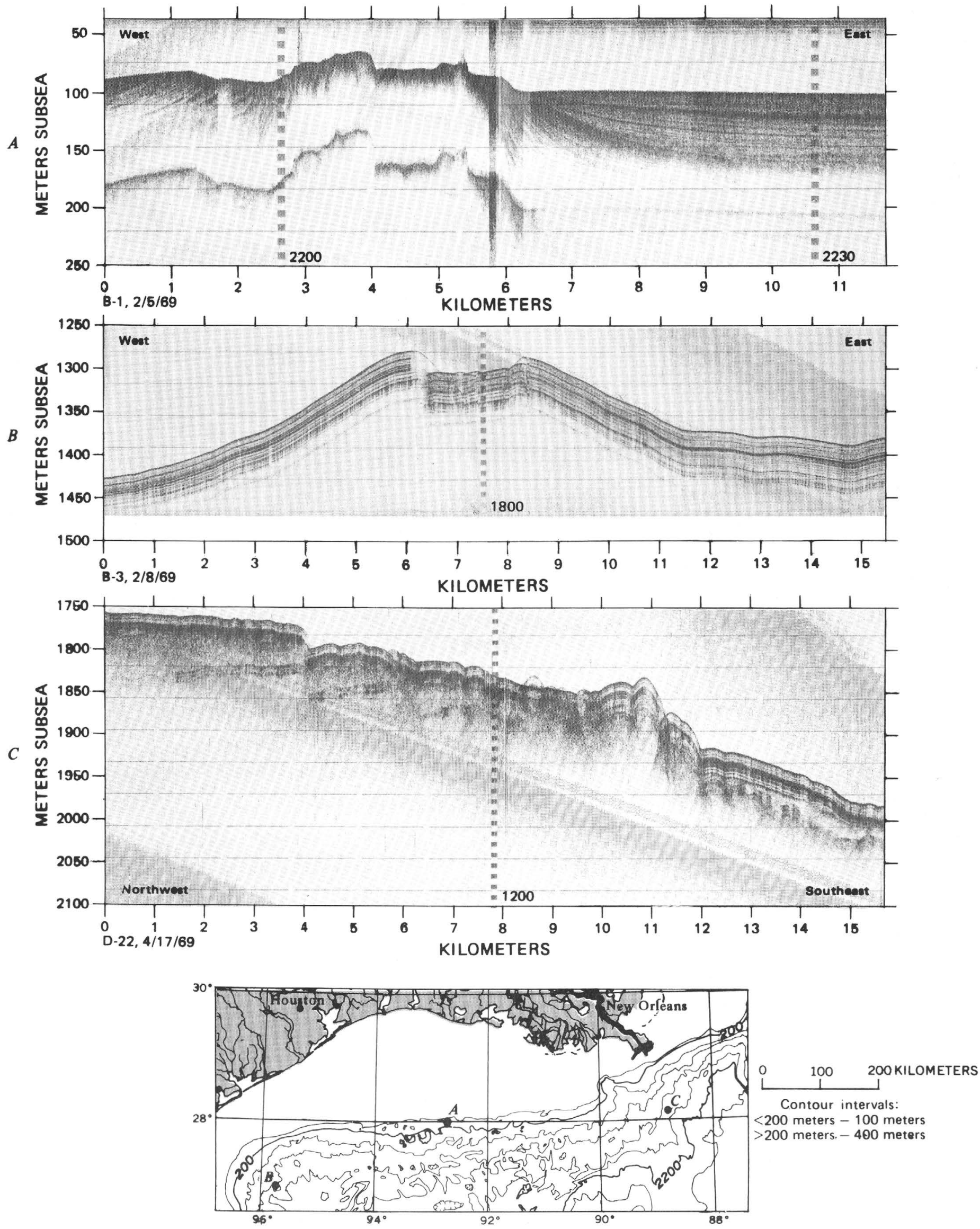
FIGURE 15.-High-resolution profiles, outer continental shelf and upper slope, northwest Gulf of Mexico, These profile segments illustrate deformational structures in the uppermost $150 \mathrm{~m}$ of sediment, some of which reflect processes originating far below. Profile $A$ shows both crestal graben and rim syncline development above a salt dome in the vicinity of the Flower Garden Banks along the same traverse shown in figures 8-10. Between kilometer 2 and kilometer 6, a plug of older sediment has been pushed up to the surface over a rising salt dome, bending the younger strata into near-vertical attitudes. The resulting syncline formed off the east flank has subsequently been filled with about $50 \mathrm{~m}$ of flat-lying shelf deposits. Tension faulting has created a graben structure in the central uplifted plug. The small peak on the crest of the dome near kilometer 5.4 is probably a welt of mobile clay extruded from the central plug along a fault plane. Profile $B$ demonstrates collapse faulting above the structural center of a growing diapir. The internal bedding of the downdropped block has not been disturbed, however, and little or no sediment has accumulated in the graben since the time of faulting. The almost $10 \mathrm{~km}$-wide area of disturbed sediment in $C$ is more than $1 \mathrm{~km}$ above a growing salt structure on the continental slope off the Mississippi Delta. The upward-directed forces of diapirism have caused the surface deposits to slump along curved shear planes with characteristically back-tilted fault blocks. The downslope displacement of these blocks has resulted in a zone of compressional folds between 10 and $13 \mathrm{~km}$. Such slumps are especially common on the heavily sedimented slopes around the Mississippi Delta. 

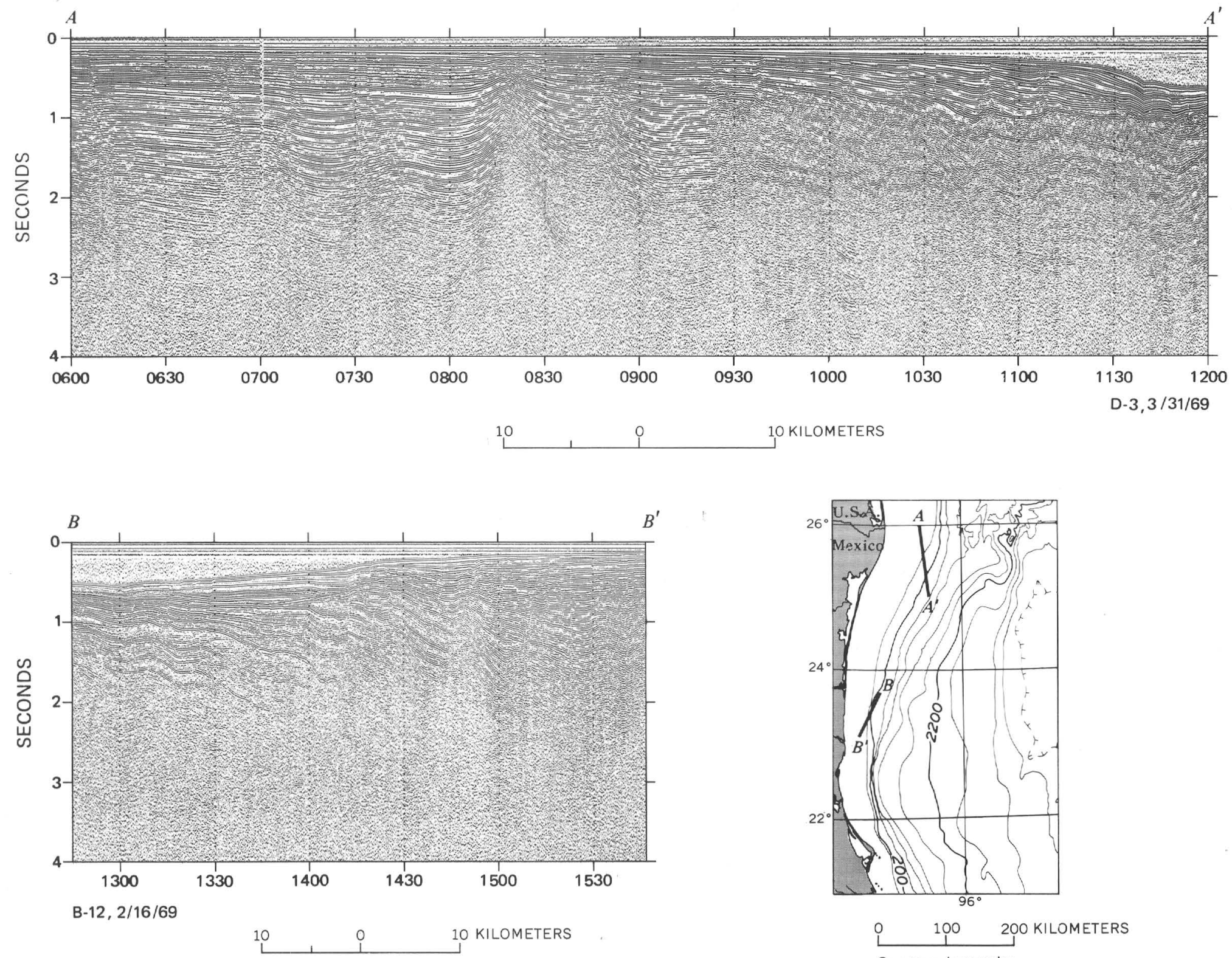

1200 10 KILOMETERS

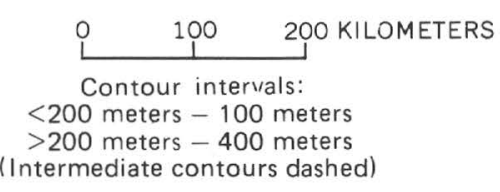


FIgURE 16.-Seismic-reflection profiles, east Mexico Shelf and upper slope, western Gulf of Mexico. The northern part of $A-A^{\prime}$ shows a shelf structure that is typical of the northwestern Gulf of Mexico (figs. 8, 9). The thick sequence of seaward-dipping beds is interrupted by faults clustered over crests of small anticlinal structures along much of the profile southward to $0815 \mathrm{hr}$. These structures are separated by well-defined synclines and appear to overlie deep-seated diapirs, although a probable salt reflector is seen only between 0815 and $0830 \mathrm{hr}$ where a slender diapir has penetrated the lower part of the sequence and displaced beds within a few meters of the sea floor. A similar structure at $0845 \mathrm{hr}$ may indicate a diapiric structure to one side of the ship's track. South of 0920 hr, a distinct change occurs in the acoustic character of the record below a rough reflecting surface at about 1.0 sec; no continuous coherent reflectors are seen below this surface. The overlying unit of $0.5-0.75 \mathrm{sec}$ of layered sediment appears to have been draped over the topography of the rough surface and has undergone no subsequent disturbance, except for minor faulting due to compaction. The rough but immobile material below $1.0 \mathrm{sec}$ and the apparent velocity inversion which it creates suggest that a reef complex may have covered part of the outer shelf in this region prior to its burial by several hundred meters of layered terrigenous sediment. It appears to have been a localized feature and probably is of no great thickness. In $B-B^{\prime}$, shelf and upper-slope beds dip southward and thicken into a small basin on the shelf north of Tampico. A diapiric structure at $1450 \mathrm{hr}$ on the north flank of this basin may indicate the southernmost limit of salt in the Rio Grande salt basin (fig. 5). Faulting occurs in the beds over the diapir and in association with folds between 1400-1430 hr. In the uppermost part of the section, faulting does not appear related to deep structure but is generally of the down-to-basin type characteristic of the Texas-Louisiana Shelf. 


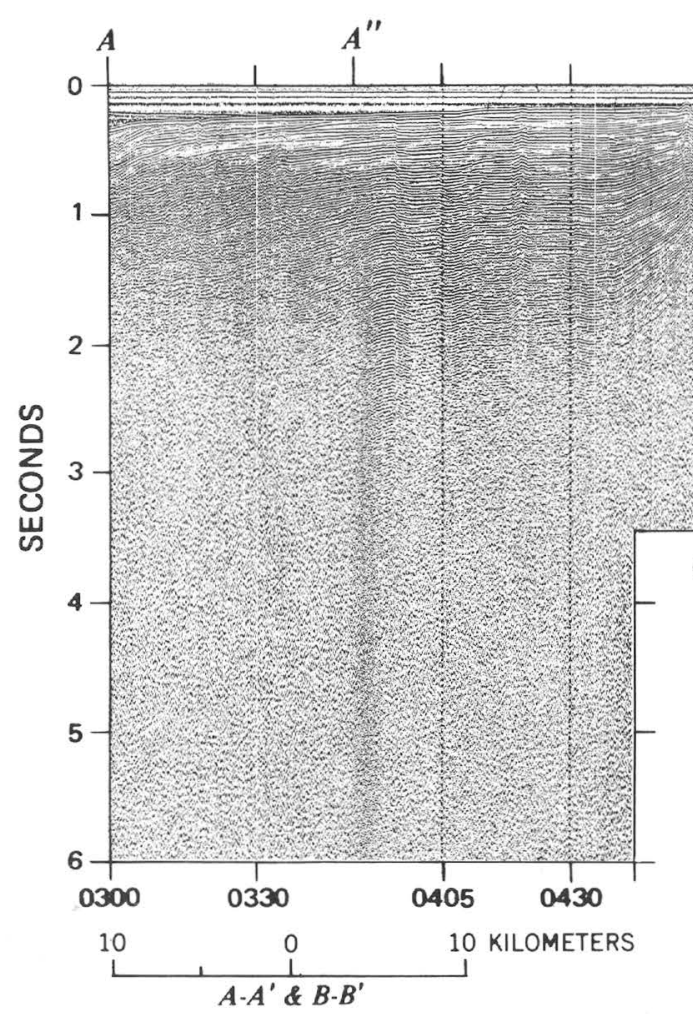

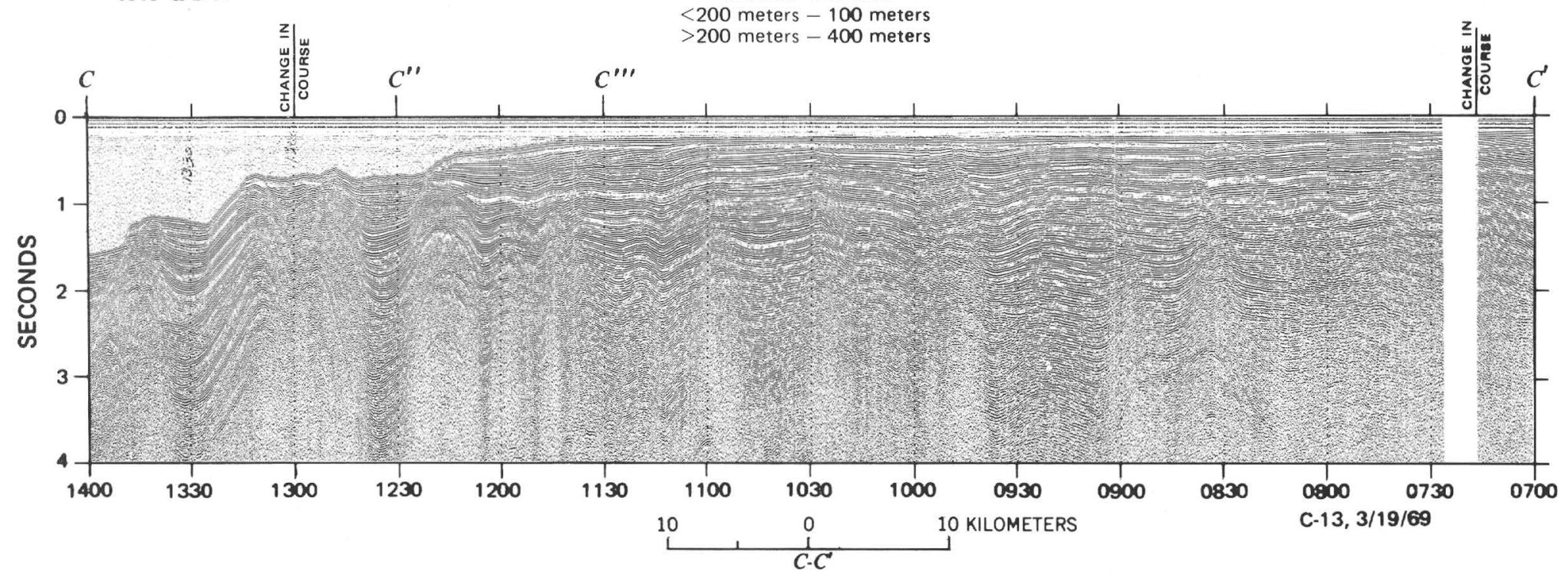

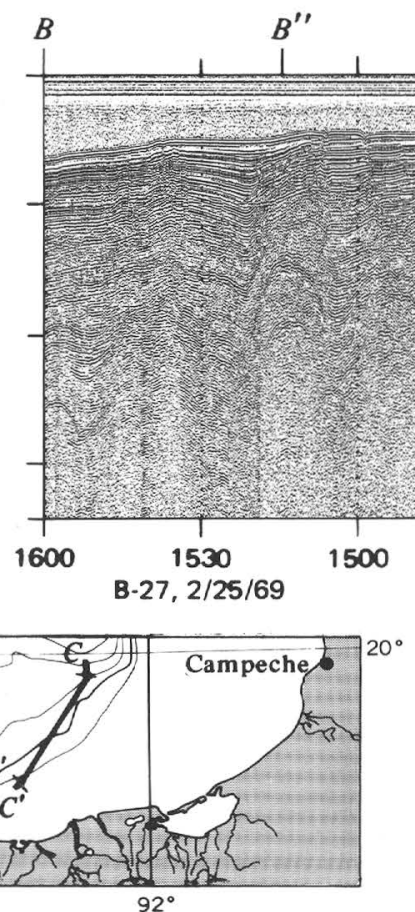

100 KILOMETERS
$B^{\prime \prime \prime}$
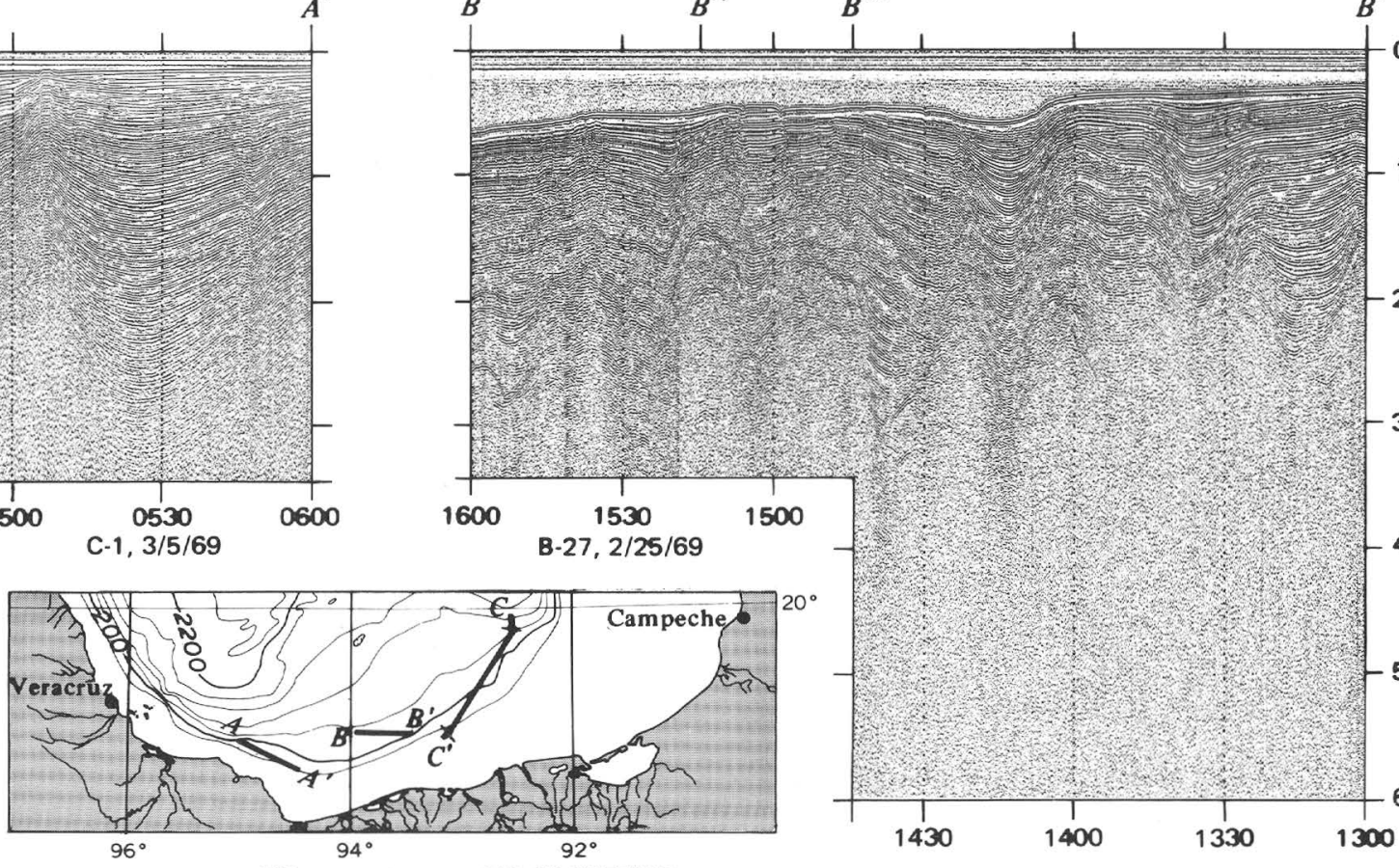

100

200 meters -100 meters 
FiguRE 17.-Seismic-reflection profiles, continental shelf and upper slope, Golfo de Campeche. Profile $A-A^{\prime}$ is almost parallel to the edge of the continental shelf about $25 \mathrm{~km}$ northeast of the volcanic terrane of the Tuxtla uplift. Here the shelf sediments dip gently seaward except where interrupted near $0500 \mathrm{hr}$. The diapiric structures at that point and the adjacent rim syncline mark the seaward extension of the western boundary of the Isthmian saline basin. Although the traverse passes near the Tuxtla uplift, evidence of a volcanic basement is not detectable in the profile. Profile $B-B^{\prime}$ is $65 \mathrm{~km}$ off the coast of the Isthmian saline basin and shows the extension of salt diapirism onto the continental slope. Tops of salt structures appear between 2.0 and $3.0 \mathrm{sec}$.

Profile $C-C^{\prime}$ extends seaward from the outer continental shelf to the head of the Campeche Canyon. It shows a thick sequence of prograding shelf sediments cut by typical down-to-basin faulting with increasing frequency of diapiric disturbance toward the north. On the upper slope seaward of $1130 \mathrm{hr}$, salt rises nearer the surface, and the sedimentary beds are more strongly distorted. The profile is quite similar to traverses across the Texas-Louisiana Shelf (figs. 8, 9). 

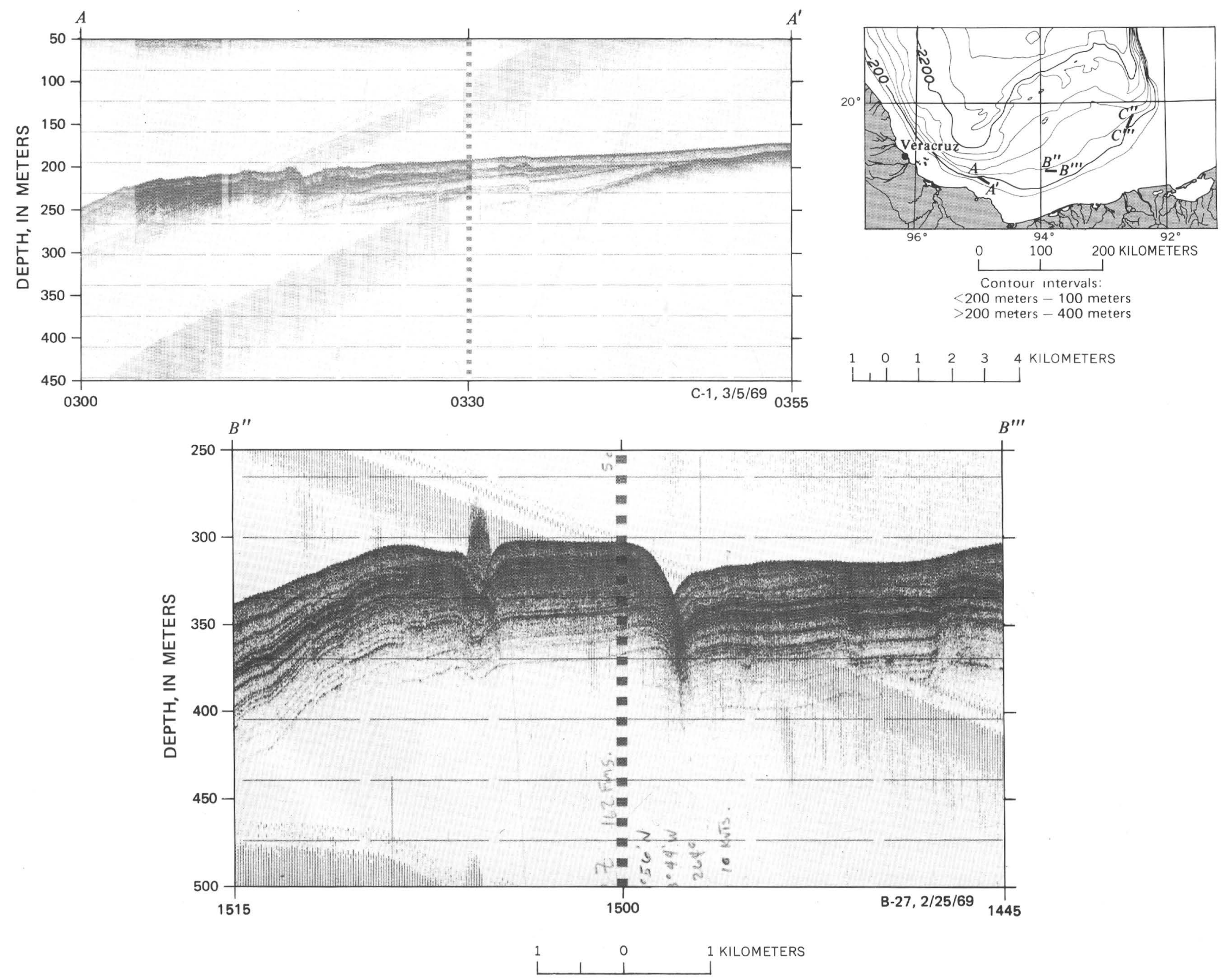


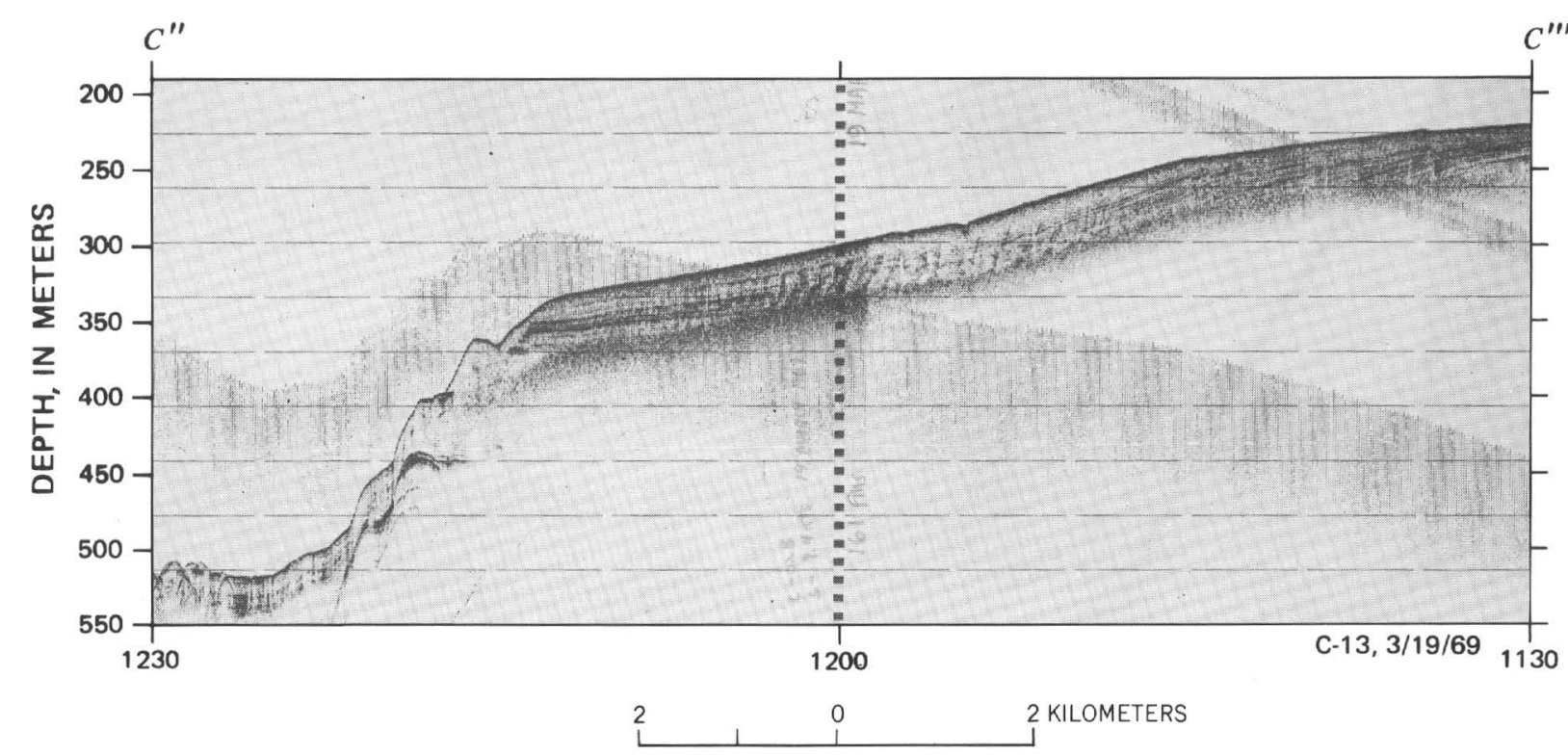

Figure 18.-High-resolution profiles, continental shelf and slope, Golfo de Campeche. These high-resolution profiles correspond to segments of the seismic profiles in figure 17. Profile $A-A^{\prime \prime}$ shows the shelf break off the Tuxtla uplift, where erosion at a depth of $225 \mathrm{~m}$ below present sea level truncated the foreset beds forming the previous shelf edge. This event probably occurred during the maximum low sea level stand at the end of the Pleistocene, and the thin blanket of sediments which covers the eroded edges and forms the present surface is of Holocene age.

Profile $B^{\prime \prime}-B^{\prime \prime \prime}$ shows the disturbance of near-surface sediment over a deep-seated diapir. The extruded welt on the crest of the uplift is thought to be extruded clay similar to that shown in figure 10. The apparent increase of vertical displacement downward in the section across faults near 1450 and $1511 \mathrm{hr}$ indicates that fault movement is concurrent with deposition.

Profile $C^{\prime \prime \prime}-C^{\prime \prime \prime}$ shows the shelf break at the head of Campeche Canyon, an area of relatively rapid sedimentation. The slope break at 1215 hr is the leading edge of a prograding mass of shelf sediment. Offlapping beds near 1130-1145 hr demonstrate the outbuilding nature of the shelf in this region. The unstable nature of these deposits is shown by the slump at $1215 \mathrm{hr}$ and the slumped material to its foot. 

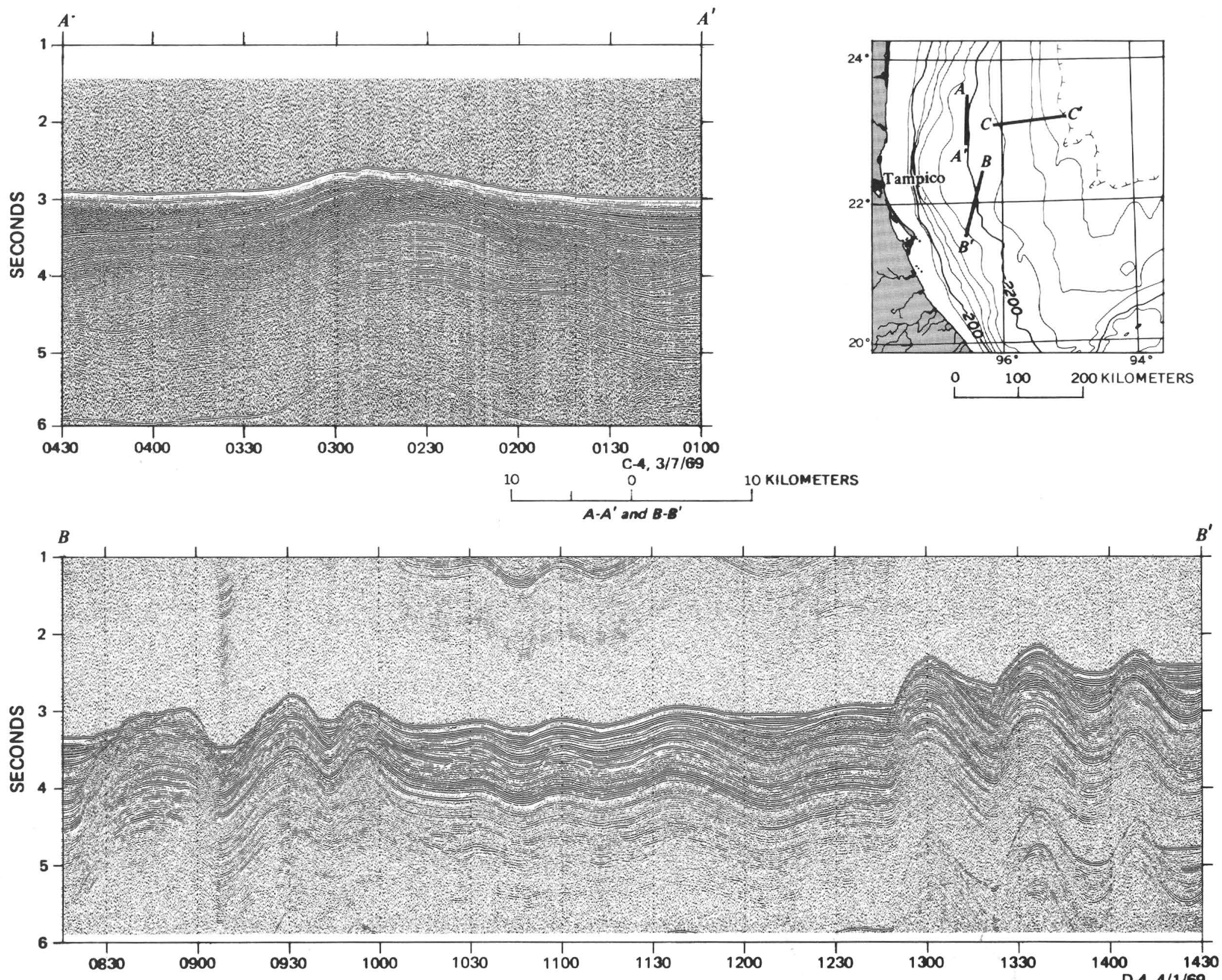


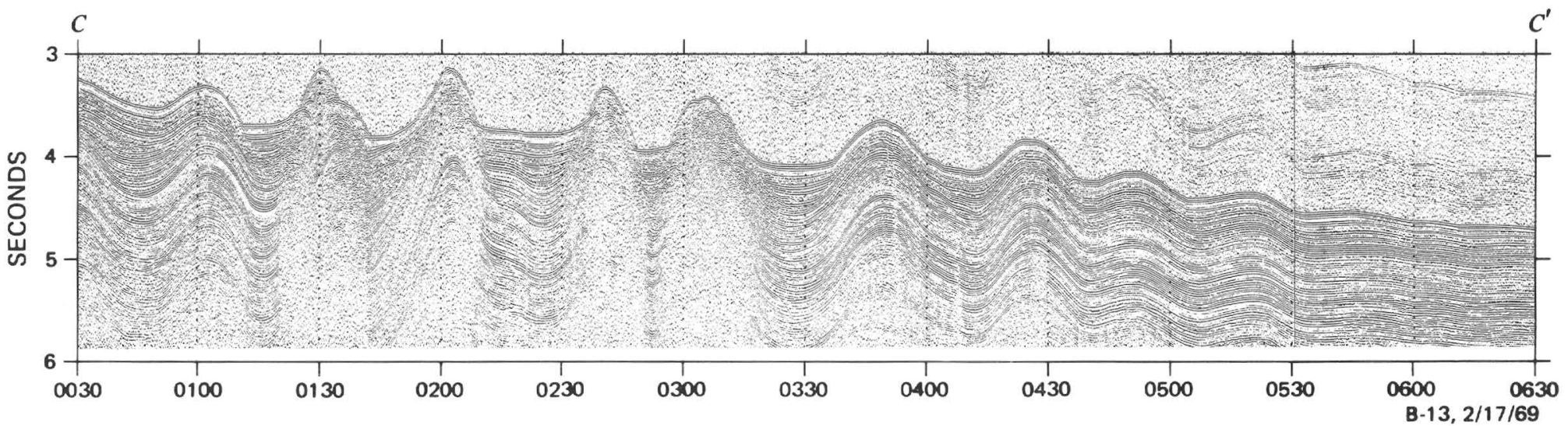

$10 \quad 10$ KILOMETERS

FIGURE 19.-Seismic-reflection profiles, Mexican Ridges, western Gulf of Mexico. The profiles in this figure are in a region of northeast-striking ridges described by Bryant, Antoine, Ewing, and Jones (1968) and shown also in figure 5 of this report. Profile $A-A^{\prime}$ crosses the crest of a ridge at an oblique angle to its strike. The apparent lower dips show more departure from parallelism of bedding planes than appears on most sections recorded normal to the trend of the slope. In the synclinal areas, small-scale dislocations and truncations of beds suggest that slumping on the flanks of ridges and current flow along troughs have been active during the folding process.

Near lat $22^{\circ}$ N., the continuity of the Mexican Ridges is interrupted by an east-west belt (zone 3 of Bryant, Antoine, Ewing and Jones, 1968) of broad, low-amplitude folds. North of this belt, fold axes strike northeast, and to the south, the ridges trend from northwest to almost north. Profile $B-B^{\prime}$ crosses this anomalous area and shows well-developed folds on either side of a 40 -km stretch of gently undulating topography. Although the amplitude of the folds in this belt is greatly diminished, the wavelength of $8-10 \mathrm{~km}$ is maintained. The uppermost kilometer of sediments in the zone of suppressed structure thins seaward and is traceable into the well-developed folds north of $1000 \mathrm{hr}$. No indication of major faulting between high- and low-amplitude folds is evident in these records. It appears that the compressive stress which formed the Mexican Ridges had a component directed inward from the edges of this profile toward the center, suggesting that two separate stress fields were involved. Only minor stress was transmitted to the central area in excess of that taken up in forming the flanking ridges, which accounts for the low amplitude of the central folds.

Profile $C-C^{\prime}$ was made normal to the trend of the continental slope northeast of Tampico (zone 2 of Bryant, Antoine, Ewing and Jones, 1968), and shows variations in the style of folding. Most typical of the entire region are the high-amplitude symmetrical upright folds such as those shown at 0100,0345 , and $0425 \mathrm{hr}$. At the base of the slope, and to some extent in the anomalous belt at lat $22^{\circ} \mathrm{N}$. (See $B-B^{\prime}$ ) are found the broad, gentle undulations similar to those at 0450 and $0520 \mathrm{hr}$. Steeper sided, more tightly compressed folds such as that at $0200 \mathrm{hr}$ are common, but of lesser abundance, whereas structures such as the ones at 0130, 0240, and $0310 \mathrm{hr}$ are scarcer. The latter features have been interpreted as diapirs and cited as evidence that salt uplift is responsible for the ridge system (Antoine and Bryant, 1969). An alternate interpretation is that such structures are normal folds so tightly compressed that bedding is destroyed or made too steep for acoustic detection. In this view, small subordinate peaks such as the one atop the ridge at $0130 \mathrm{hr}$ would be clay squeezed from the core of the fold. 

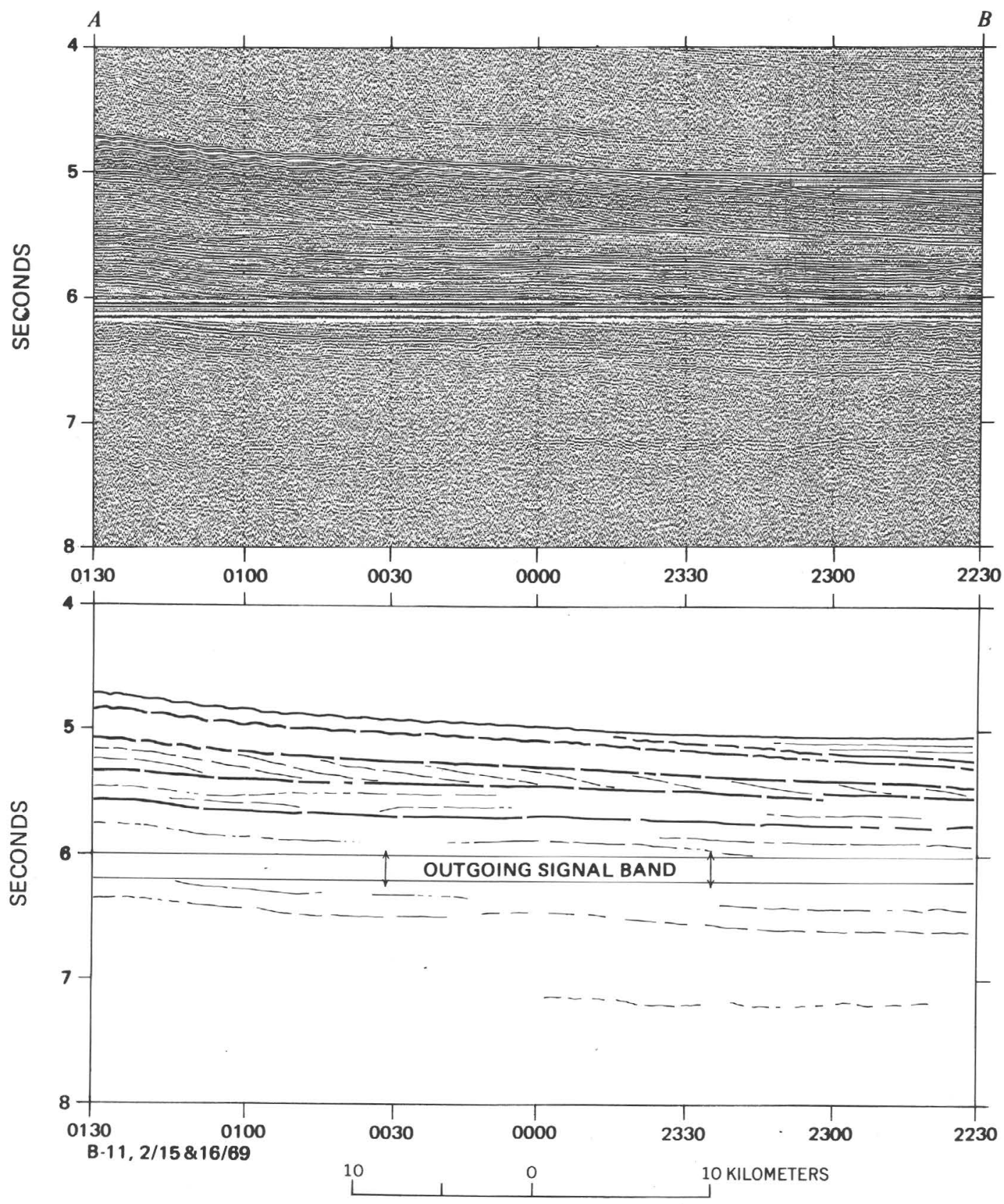

JOIDES Hole 90

(not to scale of profile)
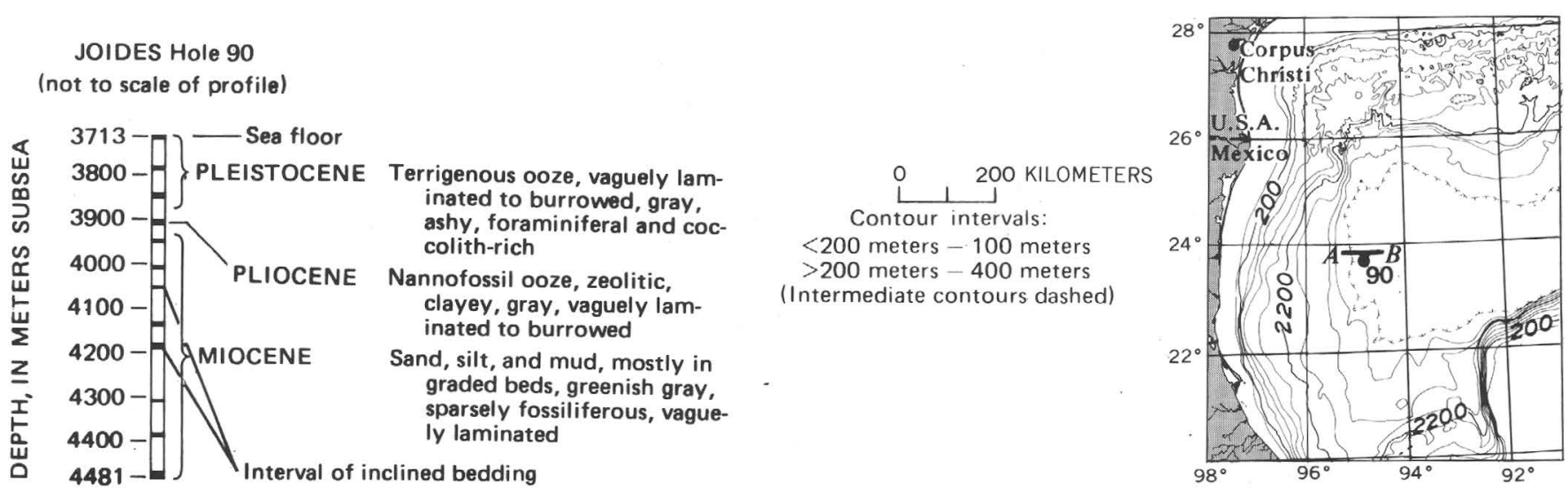
Figure 20.-Seismic-reflection profile, lower continental slope, western Gulf of Mexico. Shown in $A-B$ is an interval of large-scale cross stratification which is about $0.35 \mathrm{sec}(332 \mathrm{~m})$ below the sea floor. The interval, approximately 0.3 sec $(285 \mathrm{~m})$ thick near $0120 \mathrm{hr}$, thins basinward losing its foresetlike character near $2230 \mathrm{hr}$. It is bounded by strong, continuous flat-lying reflectors which can be traced landward into the first folds of the Mexican Ridges. Within the interval, the cross beds have an apparent easterly dip of approximately $1^{\circ} 9^{\prime}$. JOIDES hole 90 was drilled approximately $10 \mathrm{~km}$ south of $0000 \mathrm{hr}$, and a diagrammatic sketch (W. R. Bryant, oral commun., 1972) of that hole is represented in the figure. By extrapolation from the drill hole, the age of the crossbedded interval is inferred to be late Miocene. The origin of such large-scale cross stratification in the abyssal gulf poses a mystery. The lithologies encountered by the drill suggest pulsating turbidity flows, but it is not understood why such flows would produce cross stratification at these depths. Similar crossbedded sequences were noted in Kane records at about the same subbottom depth in adjacent crossings of the western gulf slope. The widespread distribution of crossbedded units in this region possibly suggests that they may be related to a time of increased tectonism in the western gulf, which increased the gradient of the slope sufficiently to cause relatively coarse sediments to flow onto the edges of the Sigsbee Plain. It is conceivable that the formation of the Mexican Ridges by décollation also began during this period. 

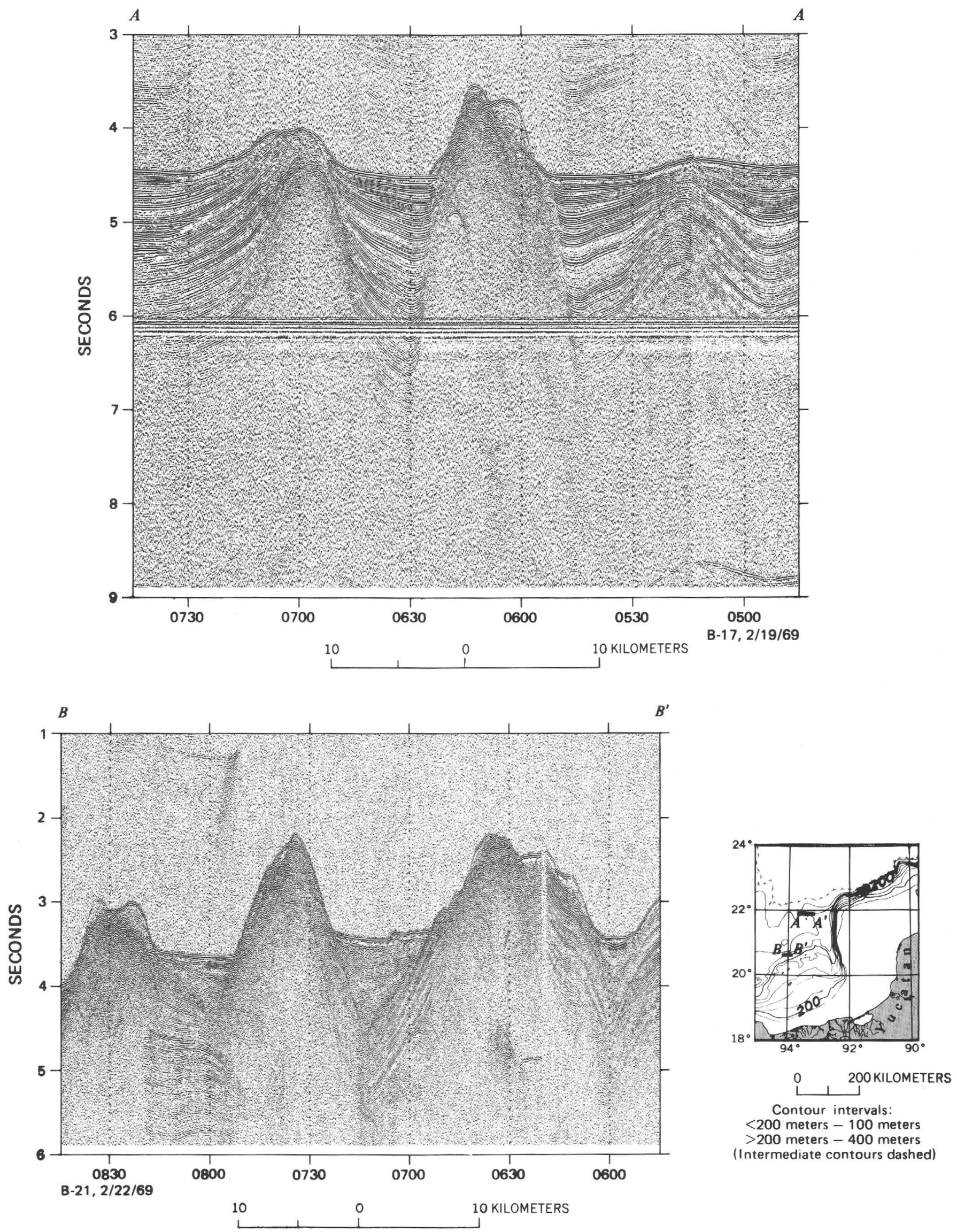

Contour intervals: $<200$ meters -100 meters $>200$ meters $-\mathbf{4 0 0}$ meters (Intermediate contours dashed) 
Figure 21.-Seismic-reflection profiles showing diapiric structures on the lower continental slope, Golfo de Campeche. Profile $A-A^{\prime}$ is an east-west section in the central part of the narrow neck between the salt diapirs on the Campeche slope and those of the Sigsbee Knolls area. The diapirs at 0615 and $0700 \mathrm{hr}$ are the only piercement structures along this track, being flanked on both sides by sediments arched over deep-seated domes. (See pl. $1, D-D^{\prime}$.) Three stages in the growth of individual salt diapirs are shown on this profile. At $0515 \mathrm{hr}$, the salt stock responsible for the well-developed anticline is deeper than about $6.5 \mathrm{~km}$ and was not detected by the seismic profiles. The strongly arched sediments mark its crest, however, and small-scale faults on the anticlinal axis allow the process of sediment removal to begin. Topographic relief is less than $200 \mathrm{~m}$. At $0700 \mathrm{hr}$, an intermediate stage shows the top of the salt core at approximately the normal sea-floor level. It has pierced the deeper layers of sediment, but the upper kilometer or so of sediment is arched steeply over the salt crest and thinned to less than half its normal thickness by erosion. Despite removal of material, however, relief at the crest is more than $400 \mathrm{~m}$. In an advanced stage of diapirism, the salt column at $0615 \mathrm{hr}$ has pierced the entire sediment column, and a probable salt top appears about $200 \mathrm{~m}$ above the level of the sea floor. Capping this salt column is as much as $700 \mathrm{~m}$ of amorphous material, which may be caprock and entrained remnants of the penetrated sediments. Total topographic relief is almost $1,000 \mathrm{~m}$.

Profile $B-B^{\prime}$, made farther south and higher on the continental slope, shows further variations of the advanced stages of salt diapirism. Although the centers of salt peaks retain a relatively constant spacing of $15-20 \mathrm{~km}$, their bases become wider toward the east, until they appear to become a single salt mass below 5 sec at $0600 \mathrm{hr}$. Relief on the taller peaks approaches $1,500 \mathrm{~m}$. On the flanks and crests of these structures, it is sometimes difficult to distinguish salt from caprock and entrained material, but the salt cores almost certainly stand hundreds of meters above the surrounding sea floor. In contrast to the structures at 0830 and $0730 \mathrm{hr}$ which have pierced the sediments, it is clear that the diapir at $0630 \mathrm{hr}$ has risen above the sea floor by another process in which the overlying sediments are shouldered aside over the emerging salt but have retained their internal bedding by conforming to the flanks of the mobile material. 


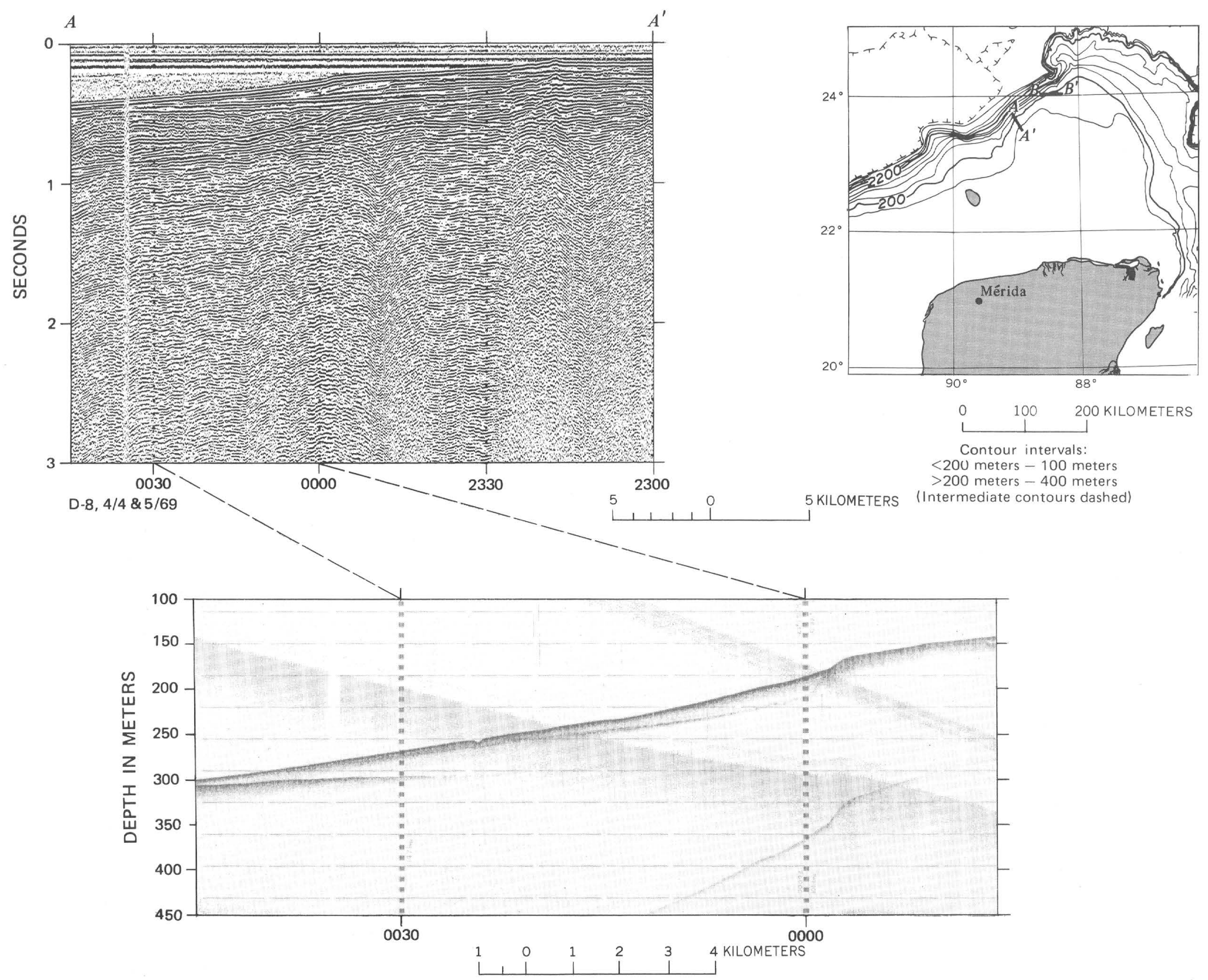




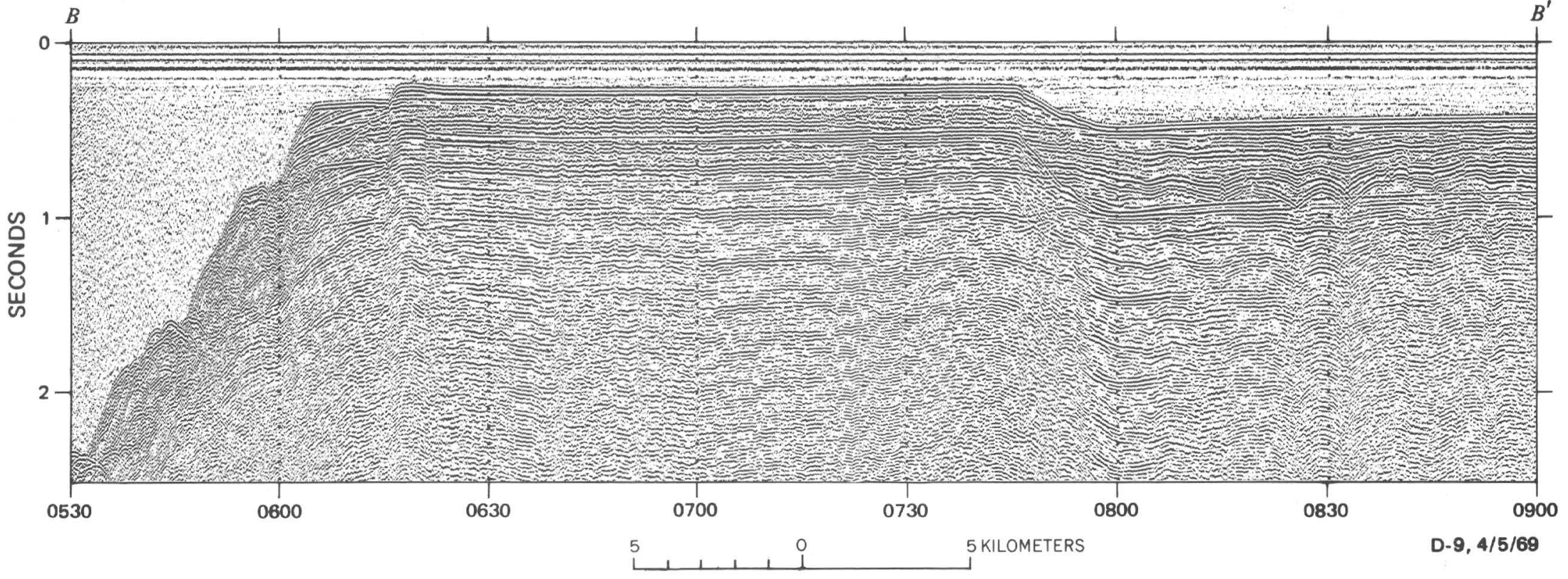

FIGURE 22.-Seismic-reflection and high-resolution profiles, Banco de Campeche. Profile $A-A^{\prime}$ across the shelf edge is complicated by the excessive multiple reflections characteristic of single-channel seismic-reflection records of limestone sections. Near the top of the section, however, a northwardthinning wedge of shelf sediment can be seen that has a seaward-sloping smooth base. Faint reflections within the wedge at the slope change, near $0000 \mathrm{hr}$, indicate its progradational history. The high-resolution profile below $A-A^{\prime}$ yields more detail on the processes that have shaped the shelf edge. The smooth base is shown at about $300 \mathrm{~m}$, above which the prograding wedge thins from $150 \mathrm{~m}$ to a featheredge on the left. Into the upper surface of the wedge, near $0000 \mathrm{hr}$, a notch has been wave cut near $220 \mathrm{~m}$ and subsequently buried as the slope was submerged. The highest surface on the right of the profile may be the seaward end of the 300-450 feet (91-137 m) terrace of Logan and others (1969). The buried, wave-cut notch near $220 \mathrm{~m}$ is deeper than any noted by those authors. Profile $B-B^{\prime}$, made about $75 \mathrm{~km}$ northeast of $A-A^{\prime}$, is also near the shelf edge. The surface of a flat-topped terrace near $0615 \mathrm{hr}$ is $240-260 \mathrm{~m}$ below sea level. Its depth and location suggest the possibility that it is a reef patch formed at the time the 220-m wave-cut notch in $A-A^{\prime}$ was made. The next lower terrace level is at $320 \mathrm{~m}$ at $0605-0615$ hr. Reflectors within this terrace indicate that it is a constructional form and was built out from the bank when sea levelwas approximately at the level of its upper surface. Other terraces are seen on the left of the profile at $800 \mathrm{~m}$ and about $1600 \mathrm{~m}$. They may be slump blocks, although it should be noted that the wavy reflectors of a buried karst are visible at about $700 \mathrm{~m}(0.8 \mathrm{sec})$ between 0800 and $0830 \mathrm{hr}$, offering the possibility that relative sea level has dropped below that horizon at some time after the formation of its limestone beds. 


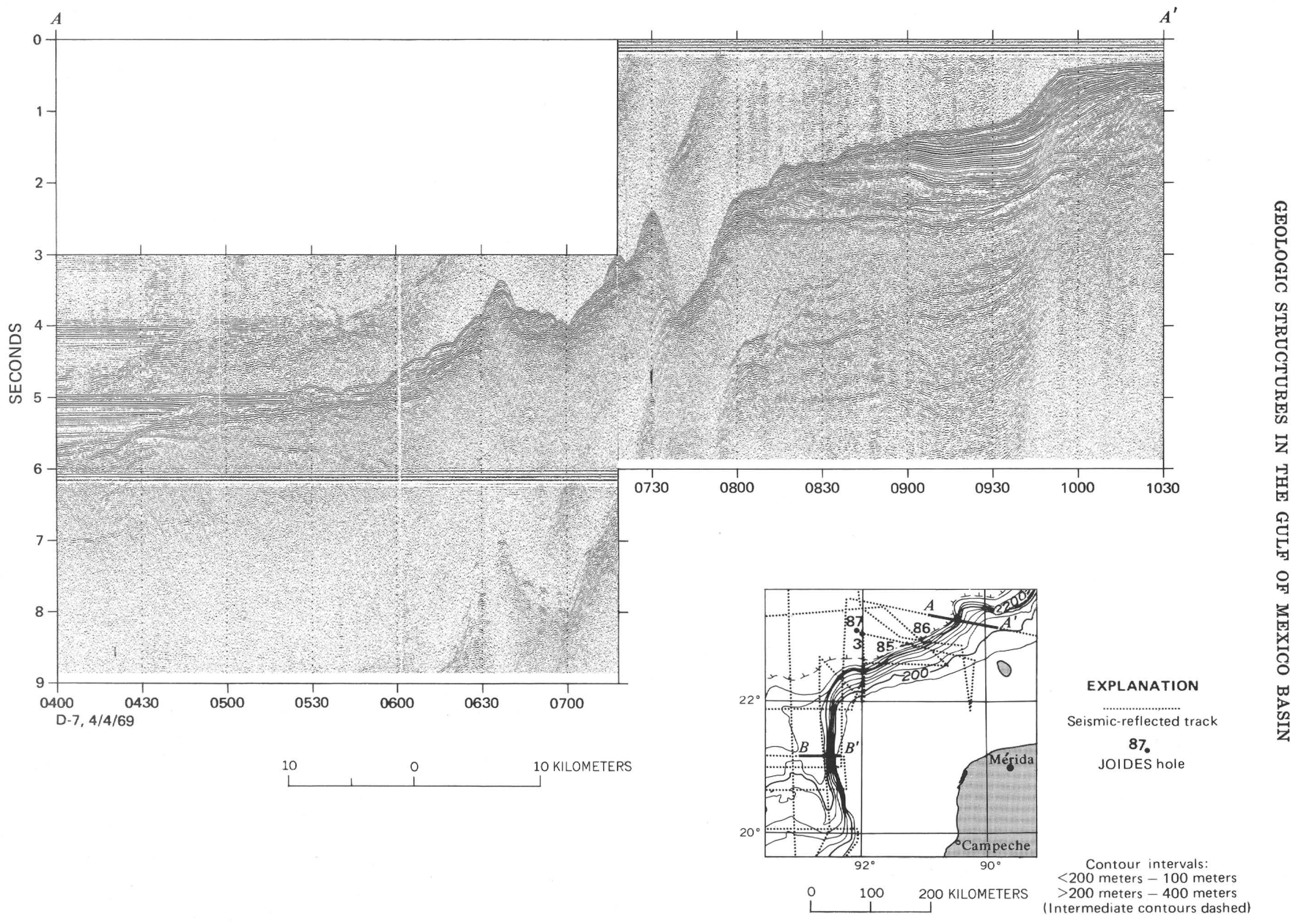




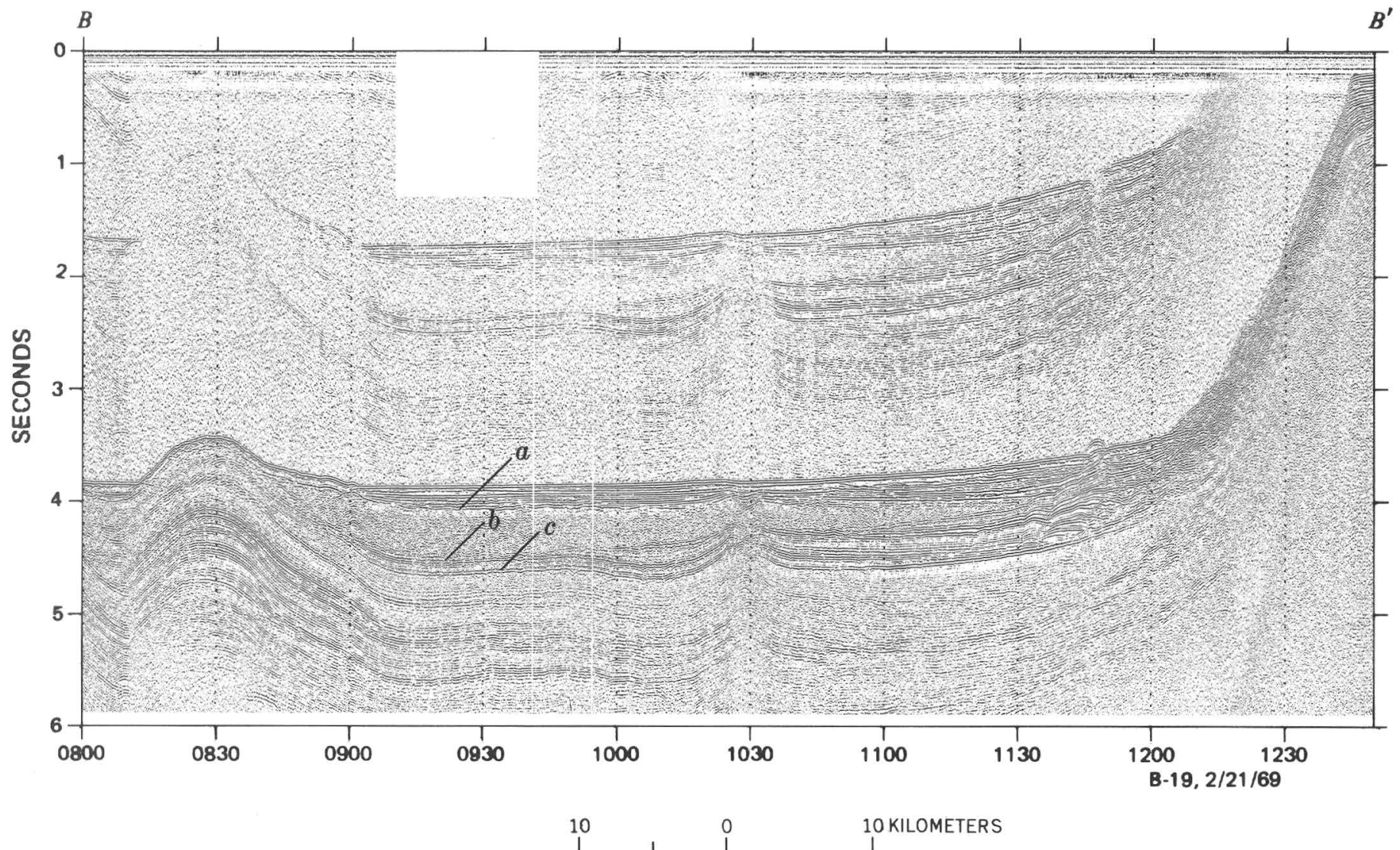

FIGURE 23.-Seismic-reflection profiles, northwestern Campeche Escarpment. Profile $A-A_{0}^{\prime}$ crosses the escarpment in an area complicated by several canyons which are visible at $0700 \mathrm{hr}$. Partly because of the angle of traverse and partly because of the canyons, the definition of an escarpment is not as clearly shown in $A-A^{\prime}$ as in $B-B^{\prime}$. Beneath the shelf break at $0950 \mathrm{hr}$ are steeply dipping beds which have built the shelf seaward to form the platformlike upper slope. The seaward pinchout of a sediment wedge has been removed by erosion of the canyons, whose sharply V-shaped axes indicate frequent flushing, possibly by turbidity currents. The group of strong horizontal reflectors beneath the upper slope at 2.4 sec can be extrapolated seaward to the peak at $0730 \mathrm{hr}$ and indicate the extent of canyon erosion. The deepest reflector in the profile appears at 7.0 sec at the left edge of the section and can be traced northwest to the Sigsbee Knolls area, where at a depth of $8.5 \mathrm{sec}$ it is at or near the top of salt postulated by Ewing, Worzel, and Ewing (1962) ; see also $E-F-G$, figure 28.

Profile $B-B^{\prime}$ crosses the lower reaches of Campeche Canyon at the foot of the Campeche Escarpment. In contrast to $A-A^{\prime}$, the escarpment here has a steep smooth slope $\left(15^{\circ}\right)$, which is characteristic of the western and eastern margins of the Banco de Campeche. Correlation of stratigraphic sections from JOIDES holes 3 and 87 (Burk and others, 1969; Worzel and Bryant, 1970) along seismic-reflection tracks shown on the index map indicate that reflectors $b$ and $c$ are near the Pliocene-Pleistocene and Miocene-Pliocene boundaries; reflector $a$ is probably the base of Holocene deposits. In this profile, the west wall of Campeche Canyon is formed by an anticlinal fold at $0830 \mathrm{hr}$, which, judging from the thinning of sedimentary units, appears to have been initiated about the close of Pliocene time by the growth of a salt diapir. Subsequent deposition in the canyon added about 0.7 sec ( $665 \mathrm{~m}$ ) of sediment to this section. The upward displacement of beds as young as Holocene in a narrow zone centered at $1130 \mathrm{hr}$ is probably the result of recent salt movement. 


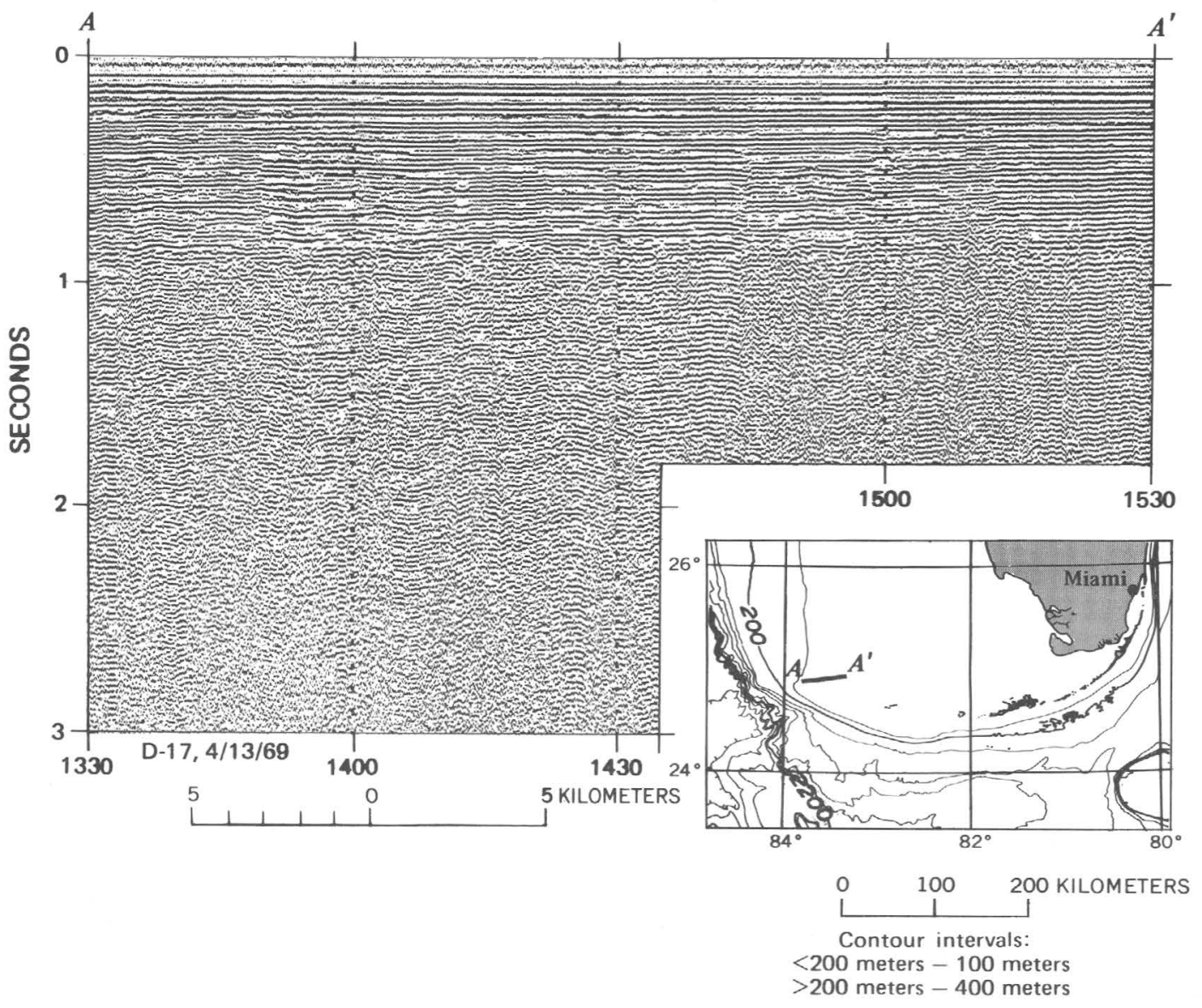


FIGURE 24.--Seismic-reflection profile, outer continental shelf, south Florida shelf. Profile $A-A^{\prime}$ is about $300 \mathrm{~km}$ west-southwest of Miami, Fla., and shows typical shelf structure common to both the Florida and Campeche carbonate banks. Because of the shallow water depth $(<100 \mathrm{~m})$ and the high reflectivity of the carbonate sediments, subbottom penetration is limited. The true bedding is obscured by multiple echoes, but a few steep fault displacements are evident. The change in acoustic character below $1.0 \mathrm{sec}$ has no ready explanation. 

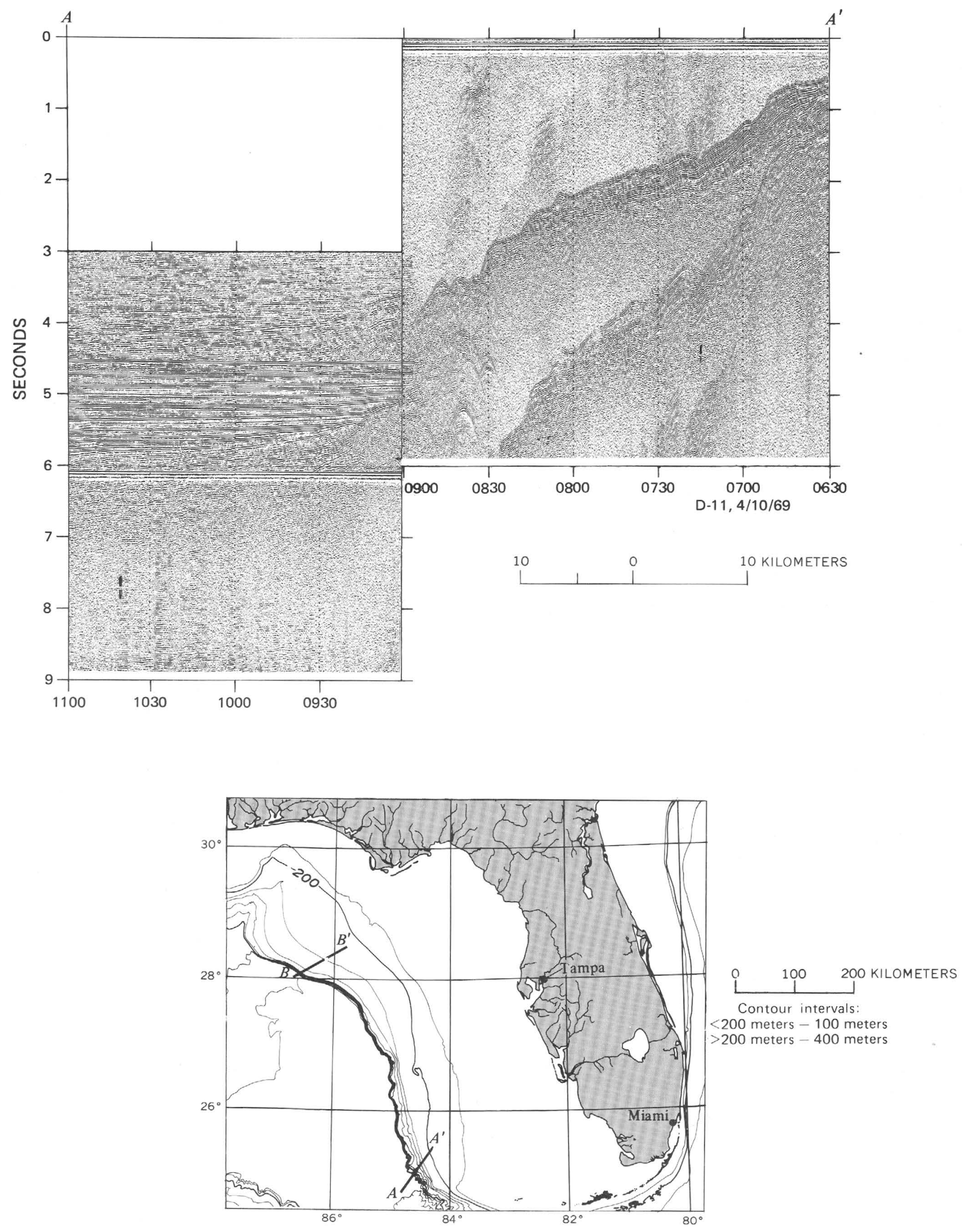


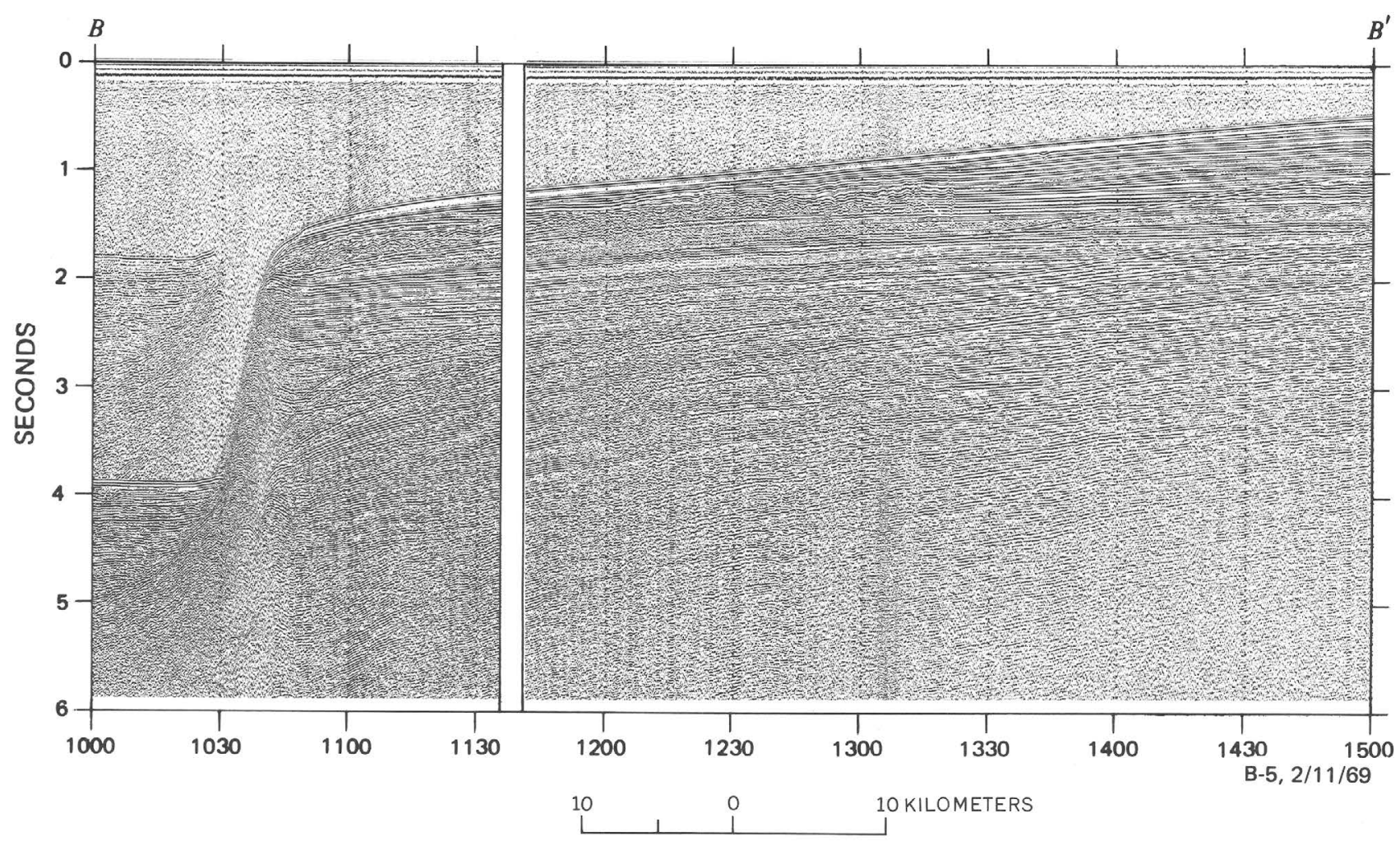

FIGURE 25.-Seismic-reflection profiles, West Florida Escarpment and upper continental slope. Bryant and others (1969) have divided the escarpment into four provinces based on topographic and seismic-profile characteristics. Profile $A-A^{\prime}$ crosses the escarpment and upper slope $350 \mathrm{~km}$ southwest of Tampa, Fla. The part of the escarpment shown in $A-A^{\prime}$ is characterized by rugged topography and hyperbolas of side reflections which add to the complexity of the record. If the reef postulated to underlie the scarp is present here, it is poorly developed and hidden by the strong hyperbolic returns recorded from 0830 to $0900 \mathrm{hr}$. Pyle, Bryant, and Antoine (1968) reported that the reef is discontinuous in the region south of lat $27^{\circ} \mathrm{N}$. Abyssal sediments onlap the escarpment from 0900 to $1000 \mathrm{hr}$ and attain a thickness of approximately $1.5 \mathrm{~km}$ at $1100 \mathrm{hr}$. In $B-B^{\prime}$, the steep escarpment typical of the northern part of the slope is shown. In the face of the escarpment, anticlinally shaped reflectors are thought to indicate the presence of an ancient reef described as being of Cretaceous (Aptian-Albian) age on the basis of dredged samples (Antoine and others, 1967). The smooth, gentle gradient of the upper slope here contrasts with the rugged topography in $A-A^{\prime}$ to the south. Prominent reflectors at $1100 \mathrm{hr}$ near 2.0 and 1.9 sec are thought to represent the tops of Lower and Upper Cretaceous units, respectively (Antoine and others, 1967). In the overlying Tertiary deposits, at least four cycles of deposition marked by prominent unconformities can be recognized. 


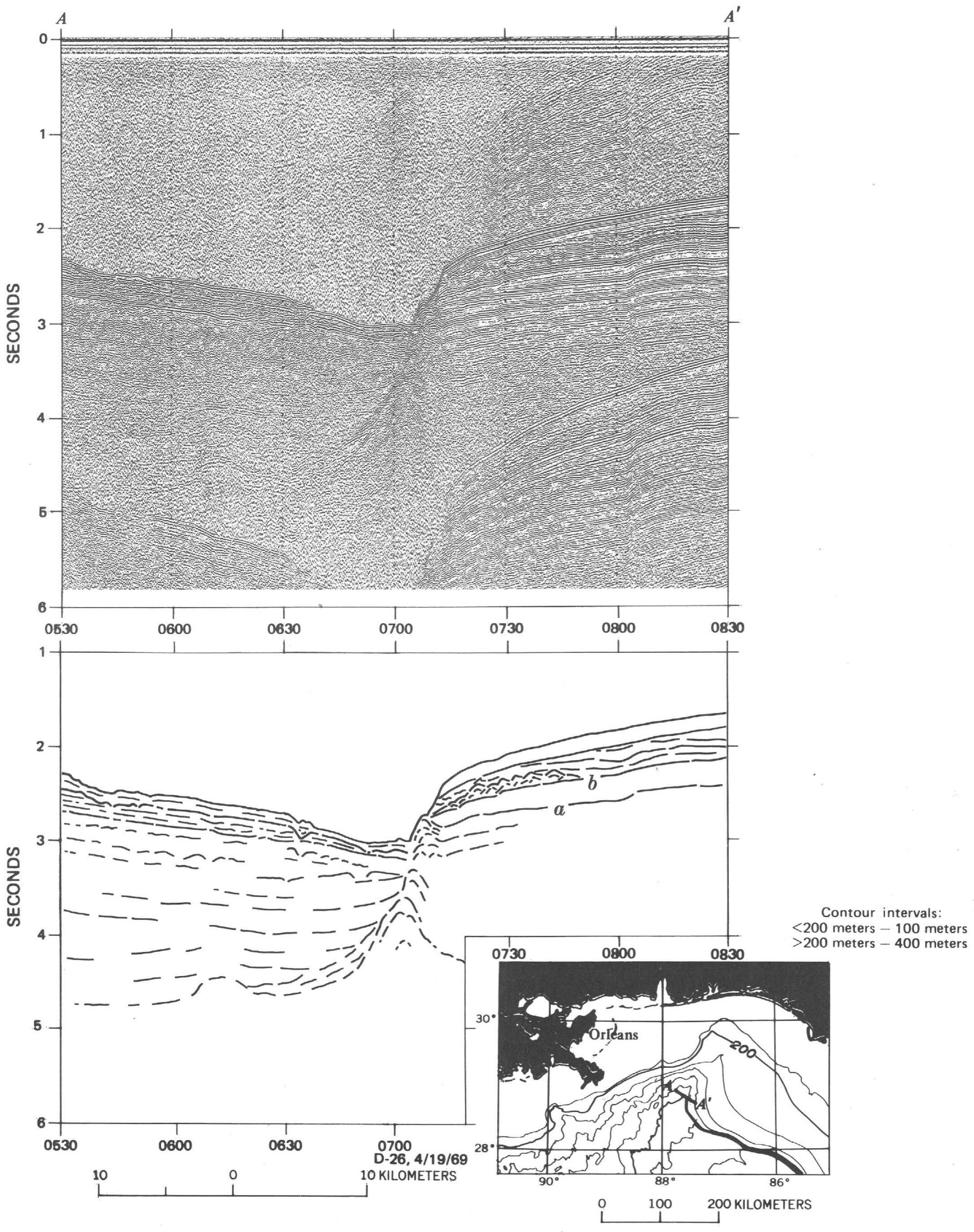


FIgURE 26.-Seismic-reflection profile, lower continental slope, northeastern Gulf of Mexico. Profile $A-A^{\prime}$ shows the juncture of the West Florida Escarpment and its upper slope (right) with the terrigenous Mississippi-Alabama embankment (left) in the lower part of the De Soto Canyon (De Soto valley, Martin, 1972). The asymmetrical, anticlinelike structure near $0700 \mathrm{hr}$ is the Lower Cretaceous barrier reef described by Antoine, Bryant, and Jones (1967) from a crossing of the escarpment about $25 \mathrm{~km}$ to the southeast, also seen in figure $25, B-B^{\prime}$. The reef appears to crop out on the sea floor at about $0710 \mathrm{hr}$. A domed reflector at $0615 \mathrm{hr}$ about 4.5 sec below sea level may represent an earlier reef or reef-talus deposits. Refiectors $a$ and $b$, as shown in the profile tracing, mark the tops of Lower and Upper Cretaceous units as defined by Antoine, Bryant, and Jones (1967). Possible Tertiary reef development, denoted by a zone of jumbled reflectors from 0715- $0745 \mathrm{hr}$ (Bryant and others, 1969), and an angular unconformity typify the Tertiary sediment cap over a broad area of the upper slope in this region. The acoustical character of terrigenous deposits in the prograding Mississippi-Alabama embankment differs sharply from that of the carbonate beds. The terrigenous sequence includes a thin upper unit of well-stratified material marked by some erosional channels and minor slump structures and a thick $(1.7 \mathrm{sec})$ lower sequence characterized by disorganized reflectors and less well defined horizons. The upper unit thins abruptly near the base of the escarpment, possibly because of either nondeposition or minor erosion caused by currents flowing down the canyon. 

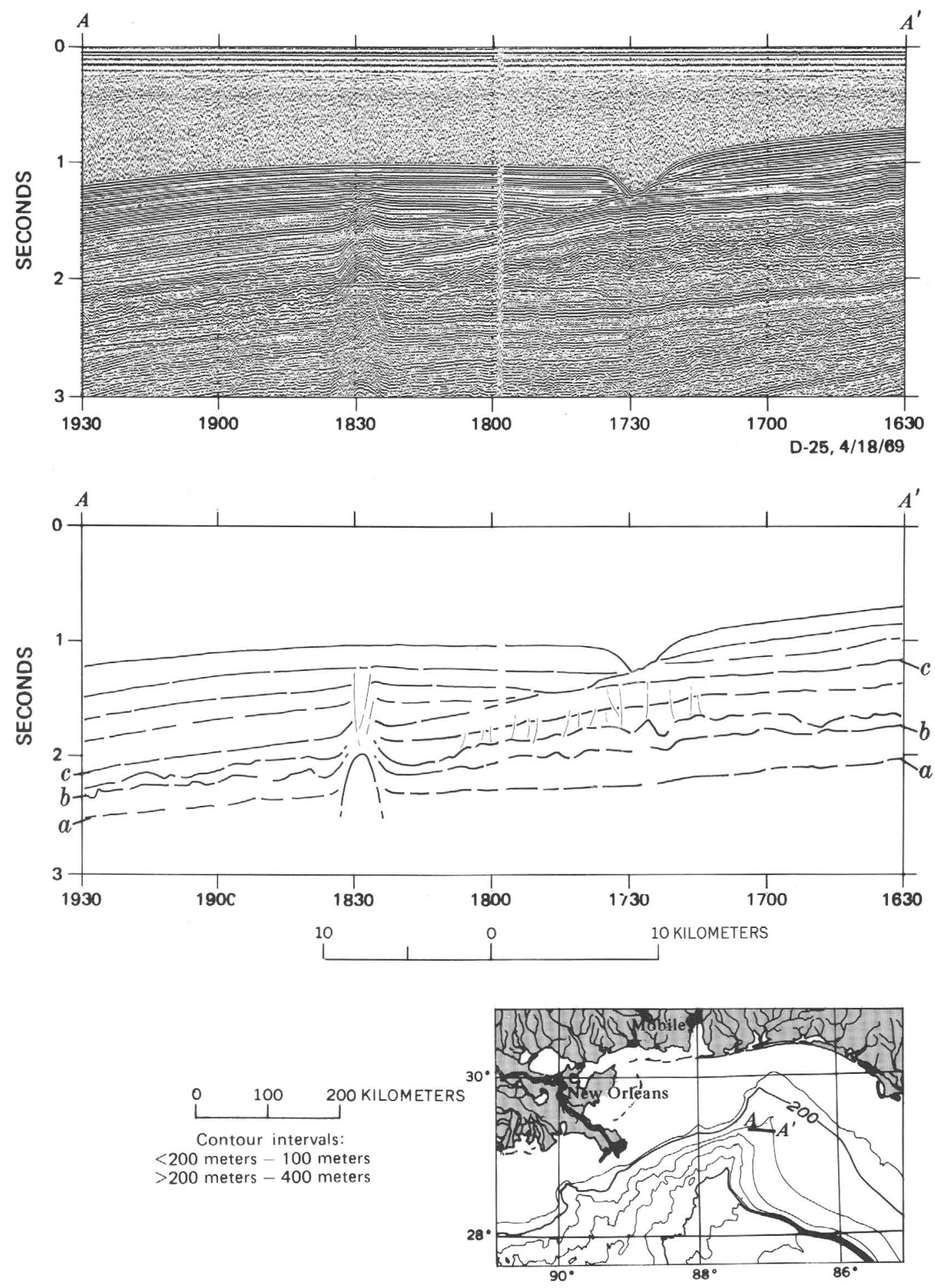
Figure 27.-Seismic-reflection profile, upper continental slope, De Soto Canyon, northeastern Gulf of Mexico. Profile $A-A^{\prime}$ shows the influence of changing source areas on the construction of the continental slope in this region. Reflectors $a$ and $b$ are near the tops of Lower and Upper Cretaceous deposits according to correlations with the refraction data of Antoine and Harding $(1963,1965)$. Until the time of deposition of horizon $c$, the sediments in this area either originated in place or were transported from the east. After that time, however, a major shift of source occurred, in which the prograding wedge of clastic material from the west overlapped the older deposits and advanced toward a junction with the slowly accumulating wedge of eastern derived clastic material. The present De Soto Canyon is at 1730 hr on this profile and represents the unclosed gap between opposing sediment wedges. A canyon origin by erosion at a lower sea level has been postulated (Harbison, 1967, 1968), but $A-A^{\prime}$ indicates little erosional effect in this part of the canyon at least. Many diapiric structures believed to represent the easternmost limit of salt domes in the northern gulf have been reported in the De Soto Canyon area (Harbison, 1967, 1968; Antoine and Gilmore, 1970). The structure at $1830 \mathrm{hr}$ is one of them. 

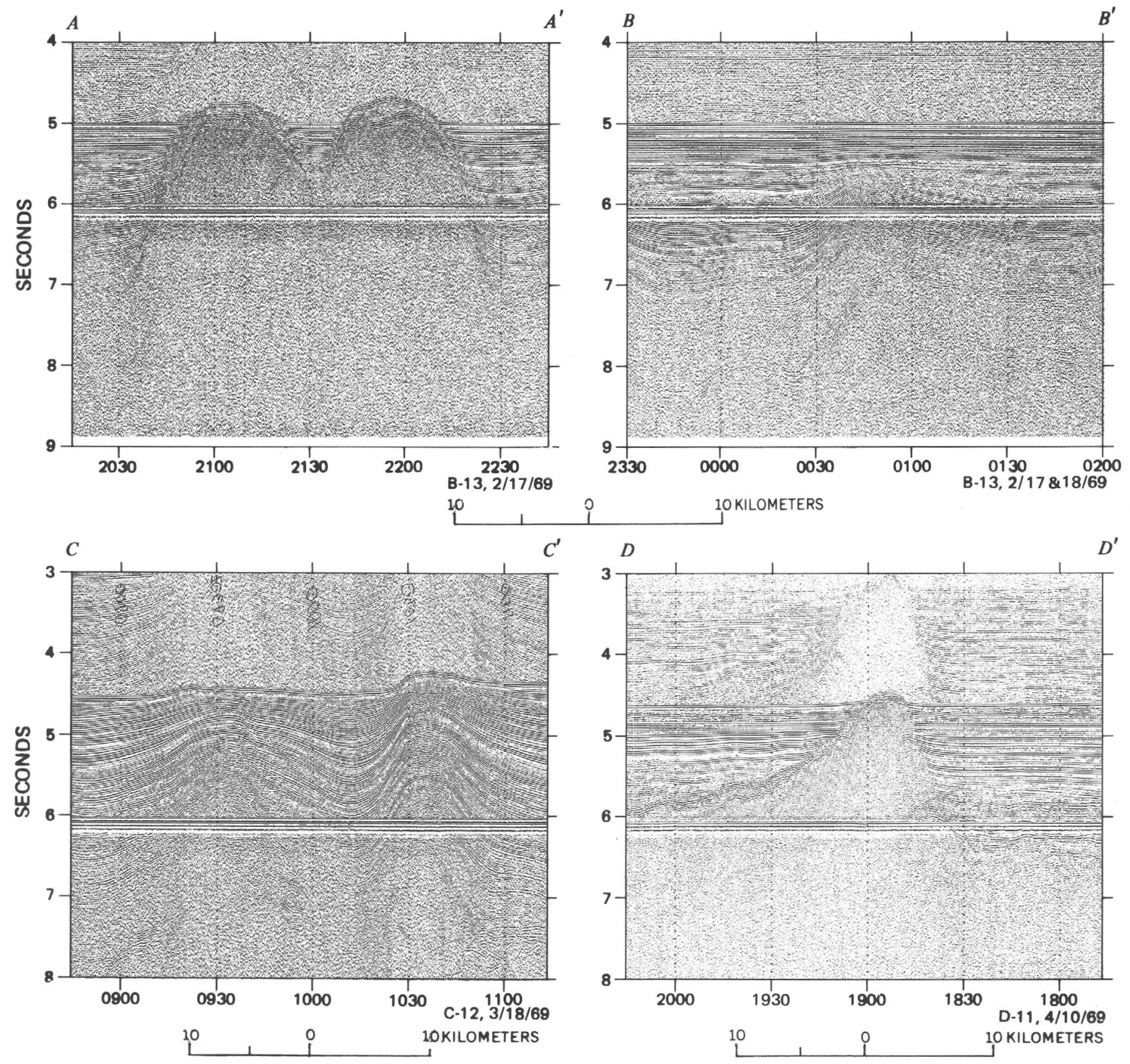
i 10 KILOMETERS
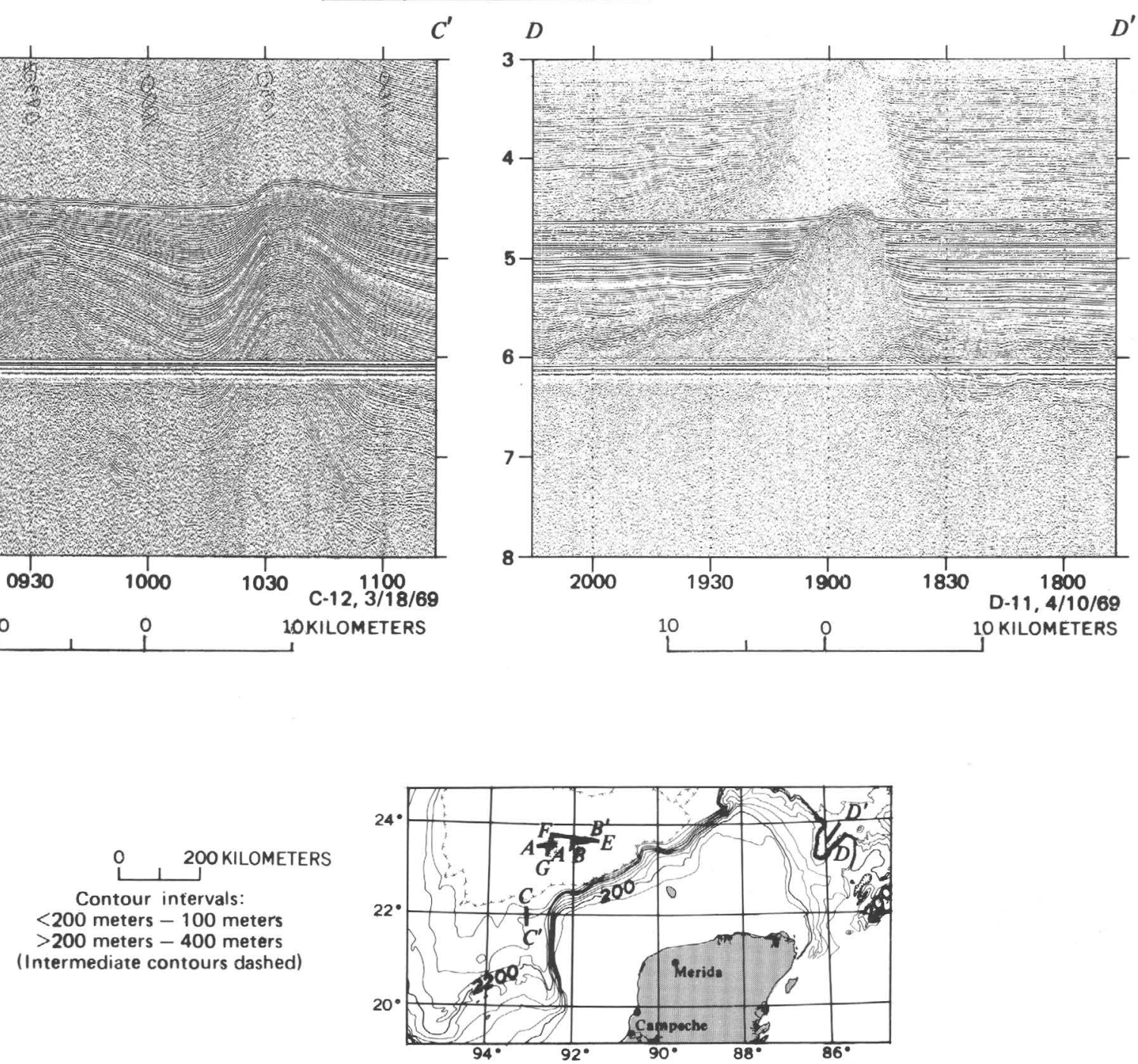


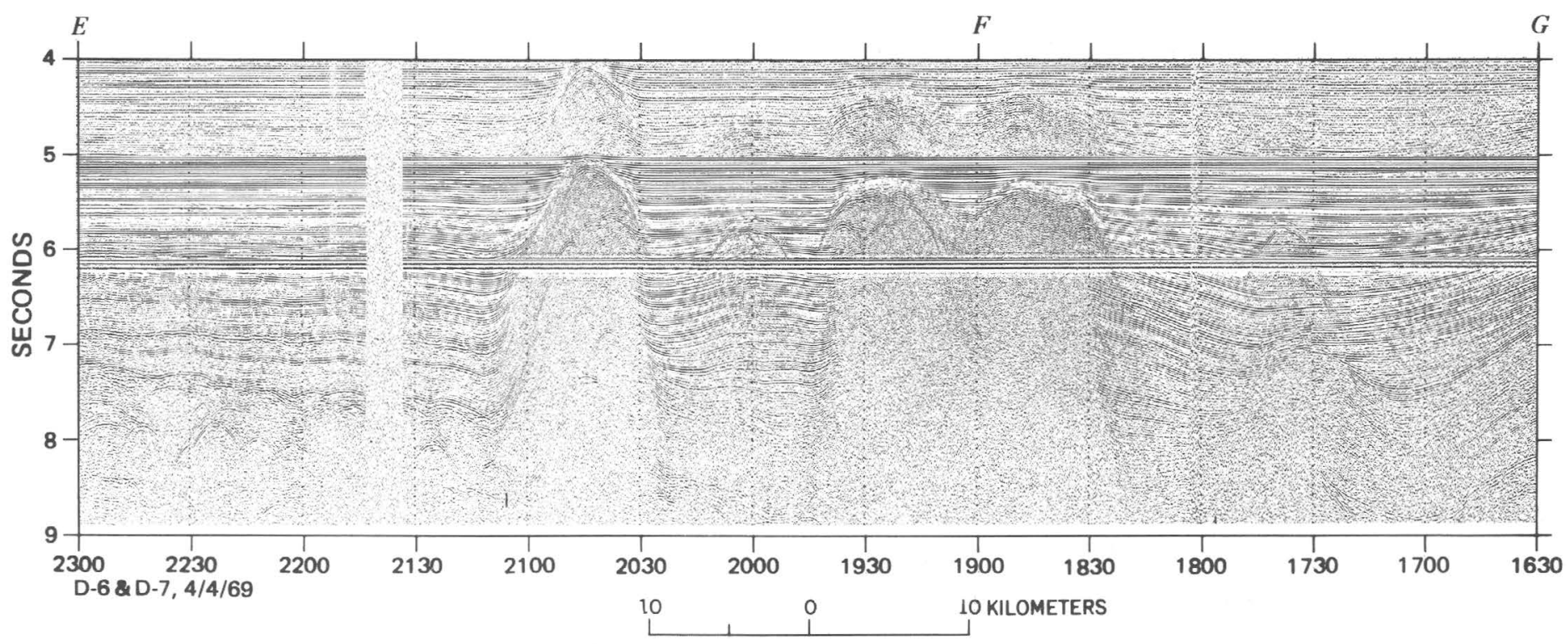

FIGURE 28.-Seismic-reflection profiles showing structure of knolls and domes in the deep Gulf of Mexico basin. Profile $A-A^{\prime}$ is an east-west traverse of two of the Sigsbee Knolls, with Challenger Knoll, location of JOIDES site 2 at left. (See also fig. 29). Each knoll contains a zone of strong reflections 200-300 m below its crest, which drilling has indicated to be a boundary between caprock and salt (Burk and others, 1969).

Profile $B-B^{\prime}$ begins approximately $14 \mathrm{~km}$ east of $A-A^{\prime}$ on the same track. It shows a dome or buried salt structure at $0045 \mathrm{hr}$. Faint reflections below the crest of the structure at $7.0 \mathrm{sec}$ outline the probable top of the salt, which forms another more subdued crest $10 \mathrm{~km}$ west $(0000 \mathrm{hr})$ at about 8.0 sec. JOIDES site 3 was $55 \mathrm{~km}$ south of this profile. In that hole, the Pliocene-Pleistocene boundary was indicated at about $250 \mathrm{~m}$ below the sea floor and the top of the Miocene at about $460 \mathrm{~m}$ below the sea floor. Extrapolation of the site 3 sediment thicknesses northward to $A-A^{\prime}$ and $B-B^{\prime}$ indicates that the strongly layered sequence above about $5.5 \mathrm{sec}$ represents all the Pliocene-Pleistocene deposits. Drag folding on the western flank of Challenger Knoll and the lack of disturbance to the upper sequence over the dome in $B-B^{\prime}$ suggest that growth of both structures stopped near the end of Miocene time. On the eastern flank of the dome at $2200 \mathrm{hr}$ $\left(A-A^{\prime}\right)$, sedimentary beds as young as Pliocene appear to have been dragged upward.

Profile $C-C^{\prime}$ is a north-south section across Nowlin's Knolls (Nowlin and others, 1965) in the northeast Golfo de Campeche. Deep-seated diapirs are visible near 1030 and $0930 \mathrm{hr}$, where salt may be at depths of more than 3.0 sec below the bottom. In the absence of a smoothing blanket of post-rise sediments, however, the anticlinal form of the structure is apparent at the surface.

Profile $D-D^{\prime}$ shows a knoll of very low surface relief in the mouth of Catoche Tongue. It differs from other knolls in the shape of the core material and in the fact that it has a magnetic anomaly and is not thought to be salt. JOIDES hole 96 was drilled near this feature, but the results are not yet reported. Horizontal reflectors adjacent to the flanks of the feature show some tendency for upturning; however, this is probably due to differential compaction rather than to diapiric intrusion. The structure itself may be (1) a volcanic plug or (2) a reef that grew atop a volcanic platform similar to other knolls in the southeastern gulf described by Pyle, Antoine, Fahlquist, and Bryant (1969).

Profile $E-F-G$ in the Sigsbee Knolls area shows a group of domes and their relationship to the sedimentary horizons of that region. In addition to the more prominent features shown, the presence of other structures not directly along the ship's track are indicated by side reflections at 1735 and $2000 \mathrm{hr}$. Most of the topography originally created by these structures has been buried by Pliocene-Pleistocene turbidites. The strong reflection zone near 7.0 sec at $E$ which dips to the right and drops off the record near $2020 \mathrm{hr}$ can be correlated with the top of the $4.9 \mathrm{~km} / \mathrm{sec}$ layer of Ewing, Worzel, and Ewing (1962), which they suggest may be salt. 


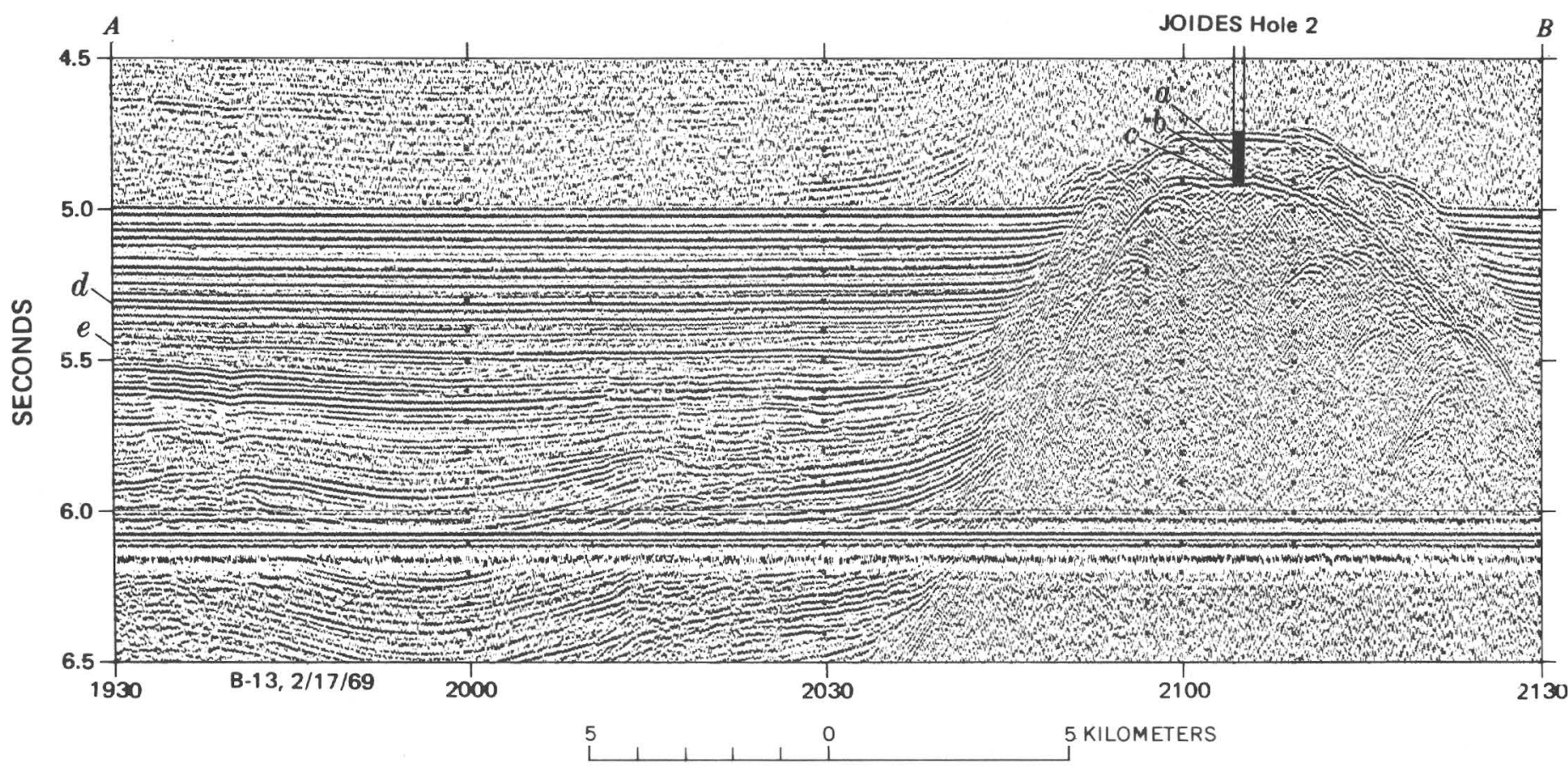

$<200$ meters -100 meters

$>200$ meters -400 meters

(Intermediate contours dashed)

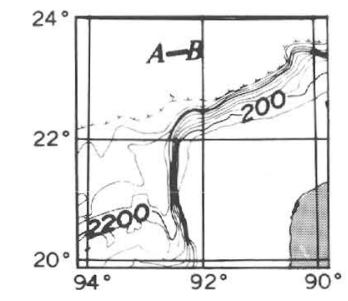


Figure 29.-Seismic-reflection profile, Challenger Knoll, central Gulf of Mexico. Profile $A-B$ is an expanded view of part of (fig. 28) $A-A^{\prime}$, showing the acoustic structure of Challenger Knoll and adjacent sediments. The probable position of the drill hole at JOIDES site 2 plotted from Kane navigation data is superimposed on the profile. According to Burk and others (1969), all sediments recovered from the upper part of the hole were pelagic clays and nanno-oozes, in which faunal analyses indicate the presence of Pleistocene, Pliocene, and upper Miocene sequences. The top of the Pliocene was found at the approximate depth indicated by $a$ and the top of the Miocene at $b$, suggesting that the knoll has stood above the base level of turbidite deposition since the late Miocene. Sulfocalcareous caprock containing gypsum and saturated with sulfurous oil was encountered at core depths of 136 and $141 \mathrm{~m}$ (c). Recent studies have revealed a Middle or Late Jurassic polynomorph assemblage in the caprock samples (Kirkland and Gerhard, 1971). The assemblage, probably derived from the underlying salt core, demonstrates the age equivalence of the Sigsbee salt with Louann Salt of the Gulf Coastal Plain. JOIDES hole 3 was drilled into the abyssal plain approximately $72 \mathrm{~km}$ southeast of the knoll. The Pleistocene-Pliocene, $d$, and Pliocene-Miocene, $e$, boundaries indicated in this hole (Burk and others, 1969) were correlated into this profile through the track crossings shown in the index map (fig. 23). Turbidites appear to compose more than half the abyssal deposits, the upper Miocene sequence being richest in the turbidite component (Burk and others, 1969). 

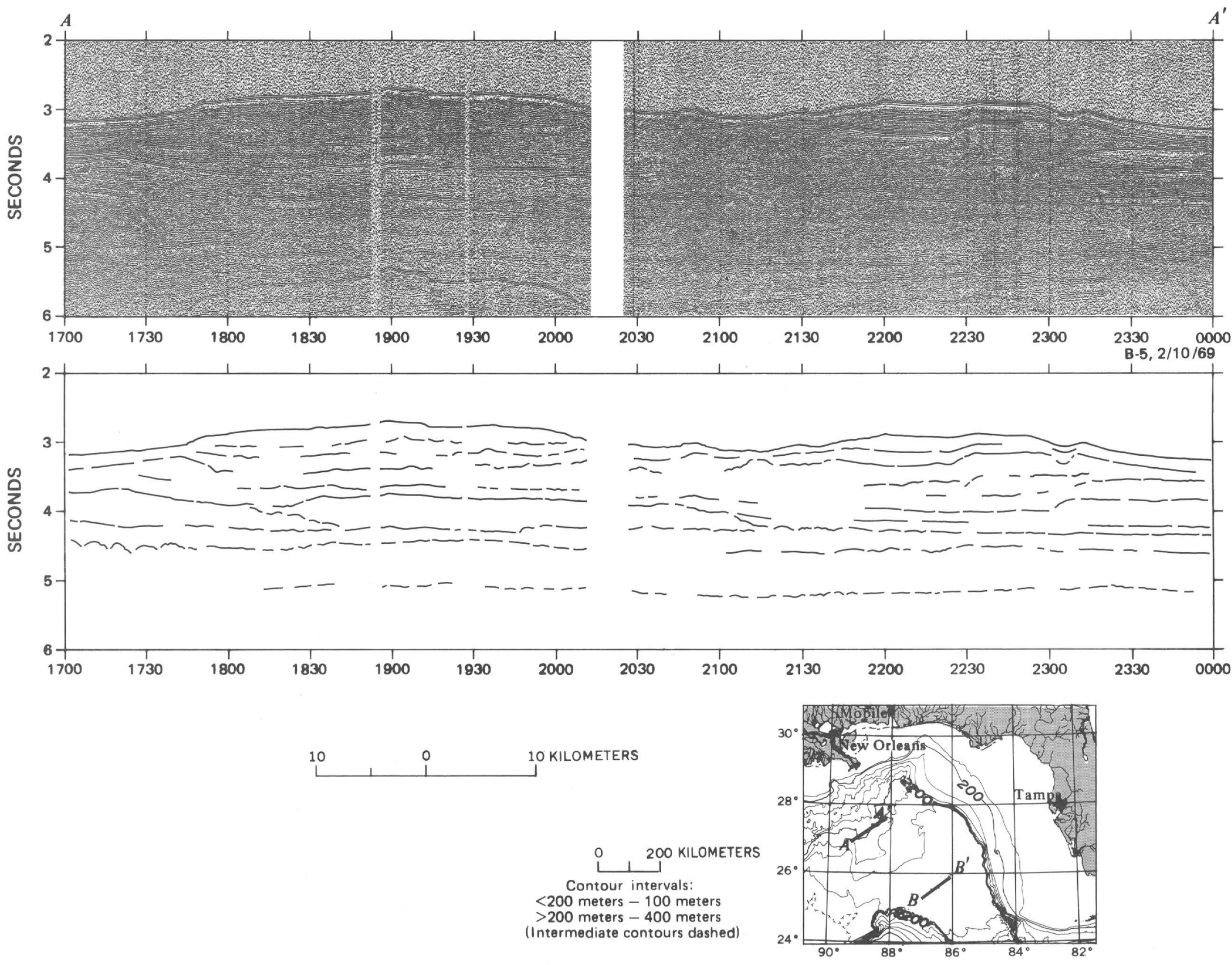


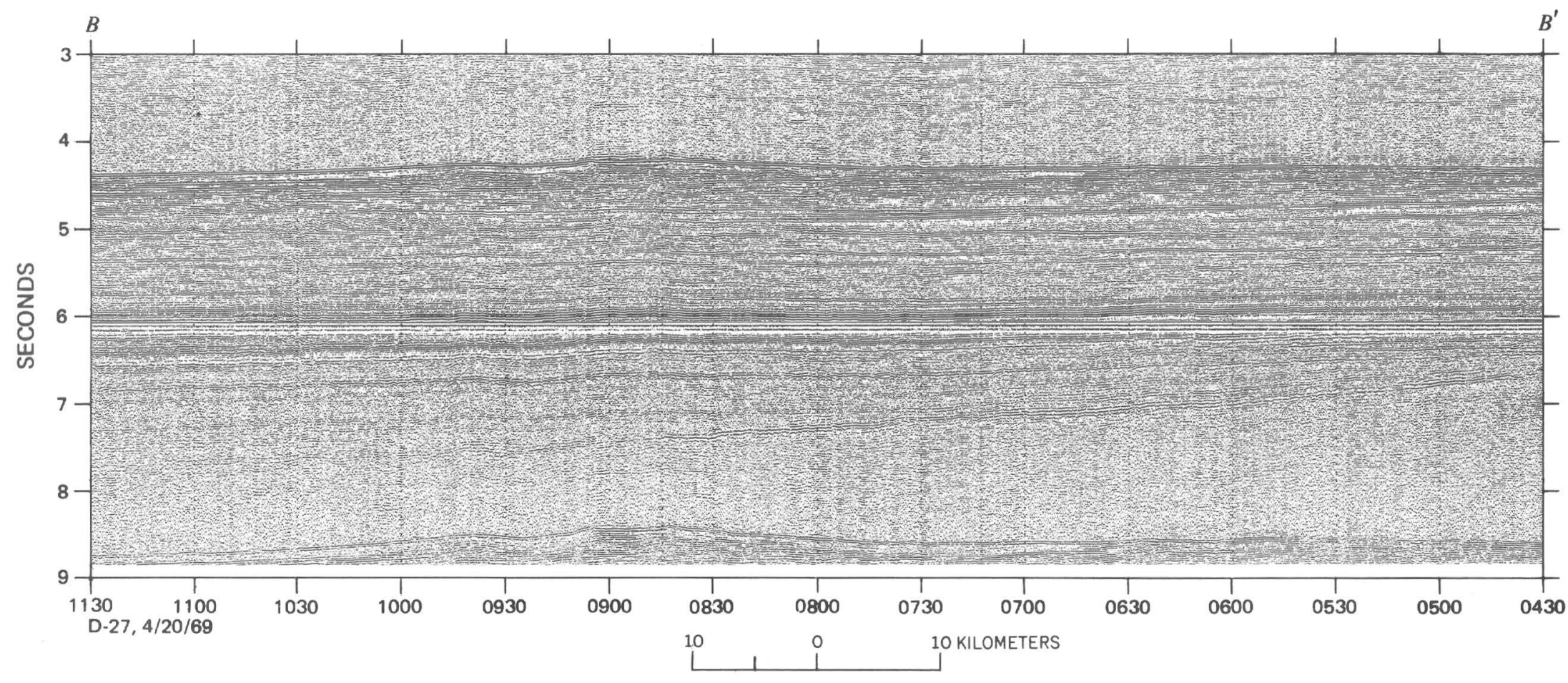

FIGURE 30.-Seismic-reflection profiles, Mississippi Fan, eastern Gulf of Mexico. Profile $A-A^{\prime}$ is an east-west crossing of the fan in water depths of about $2,200 \mathrm{~m}$; it indicates the stratigraphic complexity of the upper part of the fan. The line tracing somewhat simplifies the relationships and emphasizes certain horizons of interest. The prefan gulf floor, identifiable as the uppermost reflector with near continuity beneath the fan, is near 4.1-4.3 sec. As much as $1.5 \mathrm{sec}$ of fan deposits have accumulated above this surface in which numerous channels and buried levee features can be seen, particularly in the upper 1.0 sec of the section. The broad saddle between 2000 and $2200 \mathrm{hr}$ indicates the lobate nature of the fan, showing a clear separation between eastern and western branches. Profile $B-B^{\prime}$ crosses the fan in water depths of about $3,300 \mathrm{~m}$, more than $275 \mathrm{~km}$ southeast of $A-A^{\prime}$. The surface of the fan approaches horizontal here, with a relief of only $200 \mathrm{~m}$ in $115 \mathrm{~km}$. The deep, west-dipping reflector below 6 sec at $B^{\prime}$ is continuous to the scarp-face reflectors of the West Florida Escarpment to the right and the Campeche Escarpment to the left, indicating that it may be Early Cretaceous in age. 

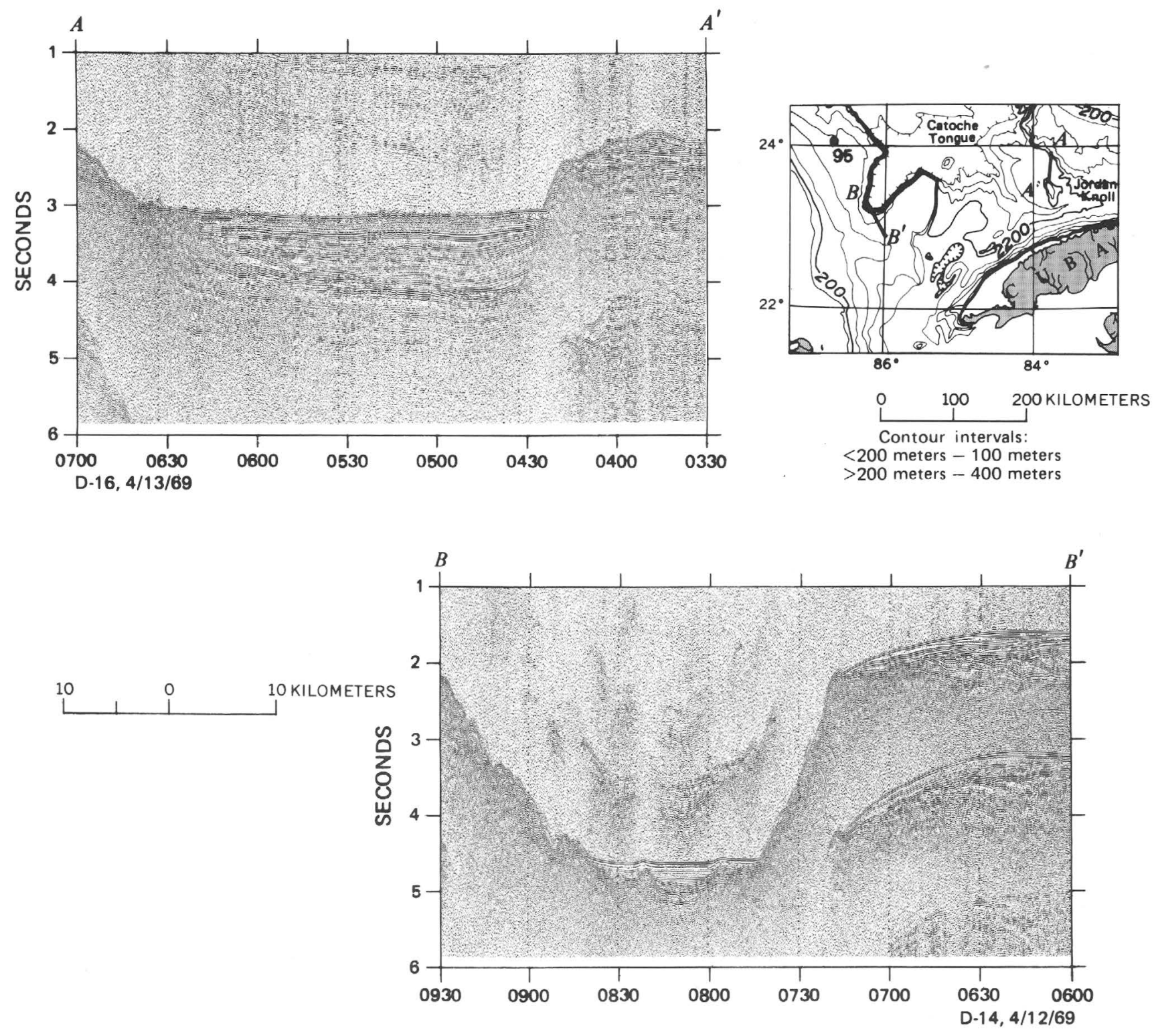
FiguRE 31.-Seismic-reflection profiles, Jordan Knoll and Catoche Tongue, southeastern Gulf of Mexico. Profile $A-A^{\prime}$ shows, from north to south, the lower part of the West Florida Escarpment, a sediment-filled trough in the Straits of Florida, and Jordan Knoll. The Lower Cretaceous reef, thought to trend southeast under the escarpment in this region (Bryant and others, 1969), is not apparent in this crossing of the West Florida "Escarpment. On the south side of the profile, however, the anticlinal shape of acoustic reflectors at the edge of Jordan Knoll indicate its presence there. Jordan Knoll has been described as an Early Cretaceous atoll separated from the West Florida Escarpment reef trend by Bryant and others (1969). These authors, as well as Pyle, Antoine, Fahlquist, and Bryant (1969), noted a total-intensity magnetic anomaly of +200 gammas and a secondary maximum of +150 gammas over the knoll, which they interpreted as being an igneous core of the atoll. Between Jordan Knoll and the West Florida Escarpment, the thick sequence of layered sediments may have been deposited as a deep-sea fan fed by a countercurrent moving west from the Straits of Florida (Hurley, 1964).

Profile $B-B^{\prime}$ crosses the Campeche Escarpment at the head of the Catoche Tongue and shows abyssal sediments deposited over rough basement topography. The north wall $(0845-0930 \mathrm{hr})$ is also rough, with no evidence of sediment accumulation in the basins and gullies which notch its slope. In contrast, the south wall (0715-0745 hr) is smooth and steep and appears to be formed by a Lower Cretaceous reef, as evidenced by the nearby dredge hauls of Bryant and others (1969) and by the anticlinal reflectors near $0730 \mathrm{hr}$ in $B-B^{\prime}$. Above the reef at a reflection depth of about 2.0 sec, a zone of rough reflectors with internal unconformities caps the older section of the south wall. Overlying this zone, the parallel bedding which characterizes clastic deposition smooths the upper slope and pinches out at the edge of Catoche Tongue. 

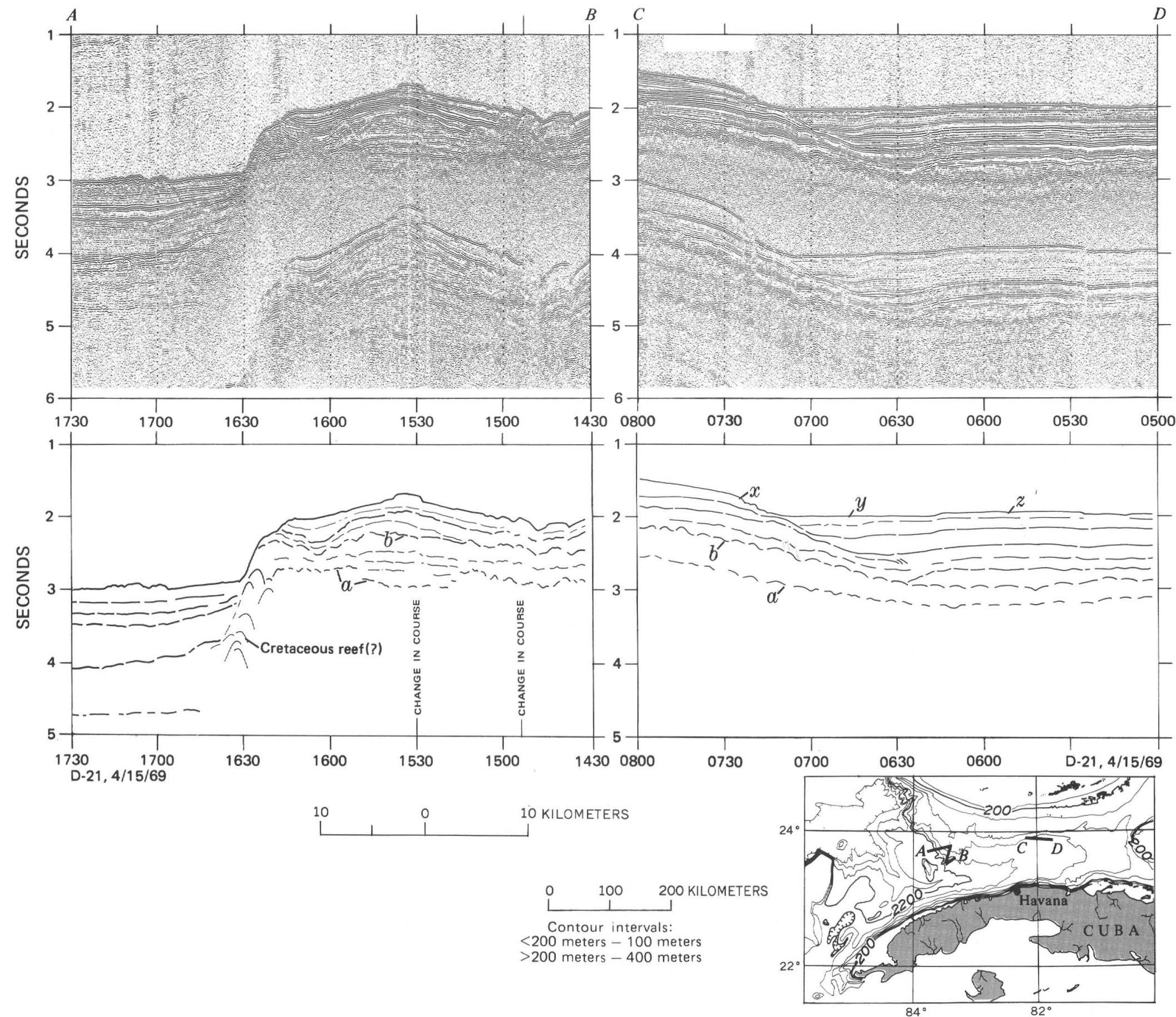

- $100 \quad 200$ KILOMETERS

Contour intervals:

$<200$ meters -100 meters

$>200$ meters -400 meters 
FIGURE 32.-Seismic-reflection profiles, Straits of Florida. Profile $A-B$ is an east-west crossing of the West Florida Escarpment about 10 km south of $A-A^{\prime}$ in figure 31. It shows the postulated Lower Cretaceous reef in the partly buried scarp at one of its southernmost appearances. Reflector $a$ has been interpreted as the top of Lower Cretaceous, and $b$, the top of the Upper Cretaceous by Bryant and others (1969) in similar profiles from the same general area. This profile shows the striking similarity between the lower West Florida. Escarpment and Jordan Knoll less than $50 \mathrm{~km}$ to the south (fig. $31, A-A^{\prime}$ ). Profile $C-D$ is about $130 \mathrm{~km}$ east of $A-B$ and crosses the Mitchell escarpment, $x$, at a low oblique angle. Malloy and Hurley (1970) have noted many scarps in the Straits of Florida which have a trough, $y$, and adjacent sediment rise, $z$, along their bases; they attribute the scarp to minor faulting and the trough and rise sequence to periodic deposition by bottom-contour currents. Reflectors $a$ and $b$ can be correlated with those shown in the adjacent profile. 


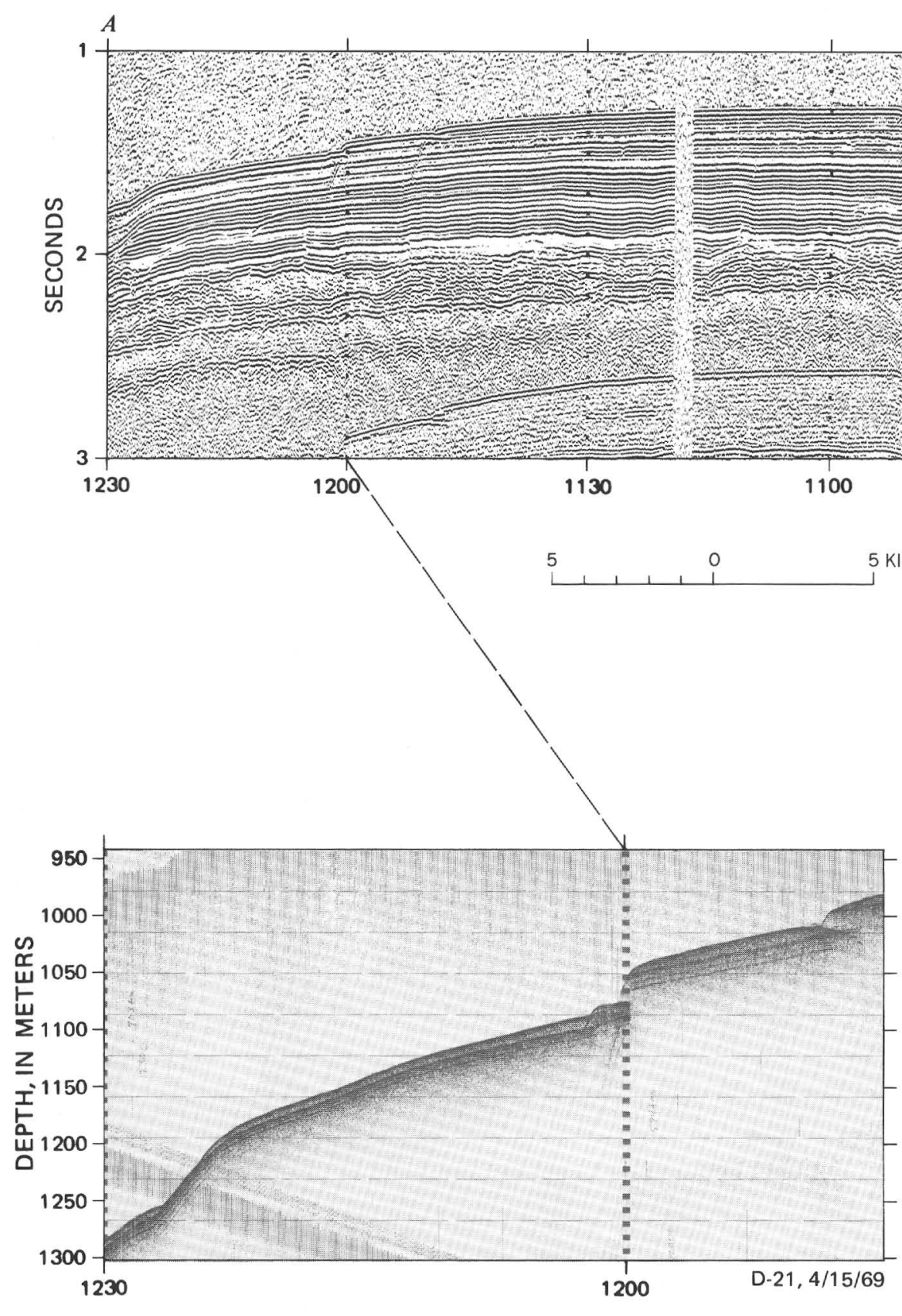

B
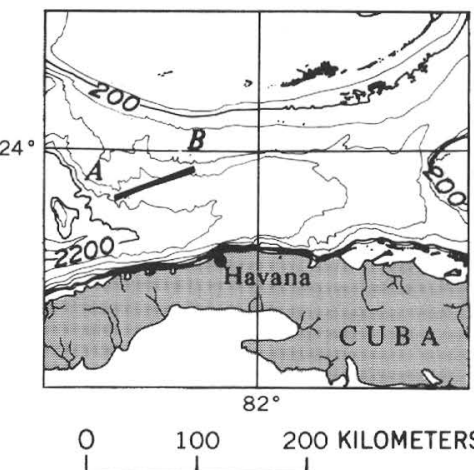

Contour intervals:

$<200$ meters -100 meters

$>200$ meters -400 meters

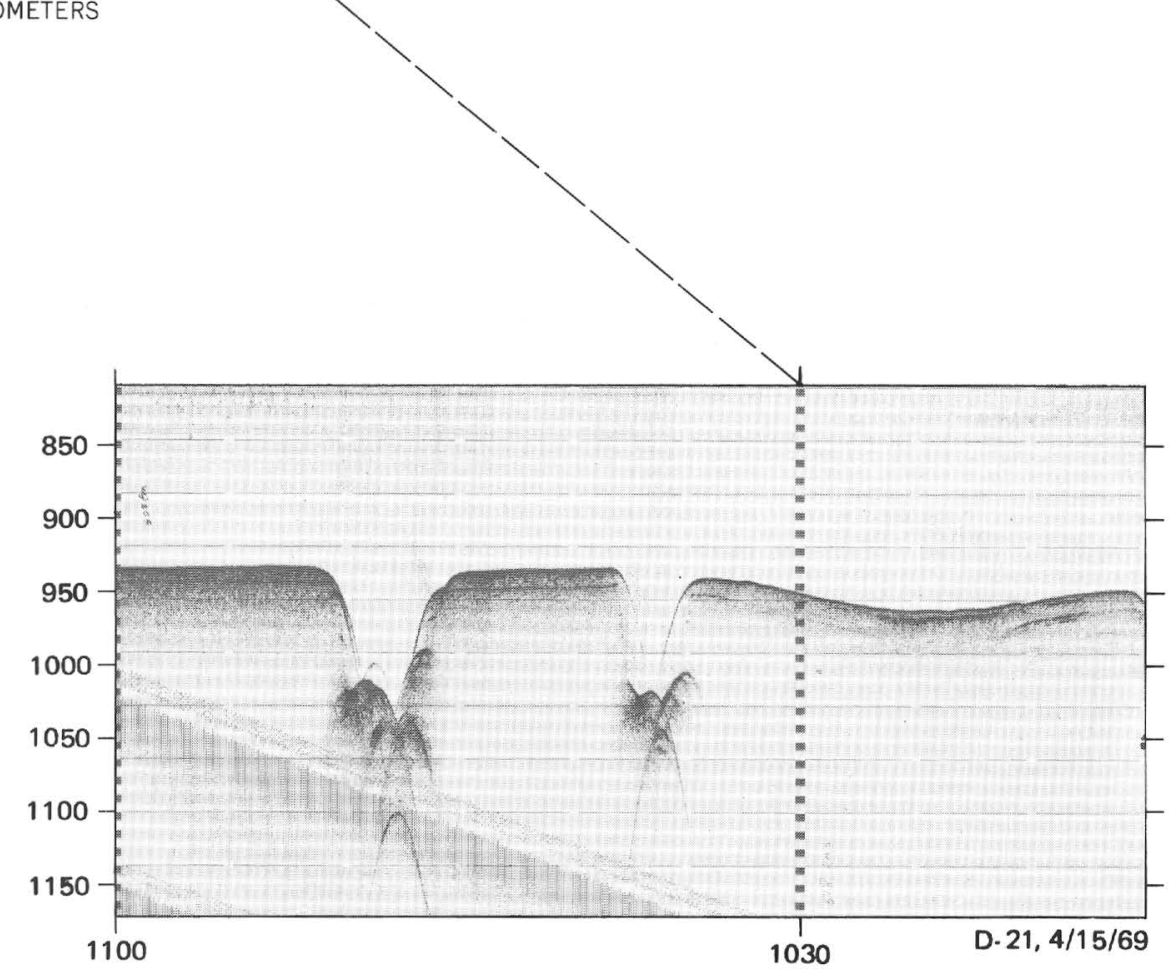


Figure 33.-Seismic-reflection profiles, Tortugas and Agassiz Valleys, Straits of Florida. The seismic-reflection profile $A-B$ crosses the eastern slope of Tortugas Valley from 1230-1200 hr and the smaller Agassiz Valleys between 1050-1010 hr. Jordan and Stewart (1961), who named and described these features, supposed them to have been eroded by turbidity currents. Truncation of deeper beds can be seen near the left edge of the profile at about 1.9-2.0 sec. The narrow Vshaped notches of the younger Agassiz Valleys have been cut downward through almost $100 \mathrm{~m}$ of sediment (1037 and $1048 \mathrm{hr}$ ). The lowermost zone of discontinuous reflectors at about $2.3 \mathrm{sec}$ correlated with the Lower Cretaceous reflector $a$ in figure 32 ; the inferred top of Upper Cretaceous beds, reflector $b$ in figure 32, appears at about $2.1 \mathrm{sec}$ in the center of the profile. The accompanying high-resolution sections show displacement across minor slump faults on the slope of Tortugas Valley, and the narrow sharp profiles of two of the Agassiz Valleys. 

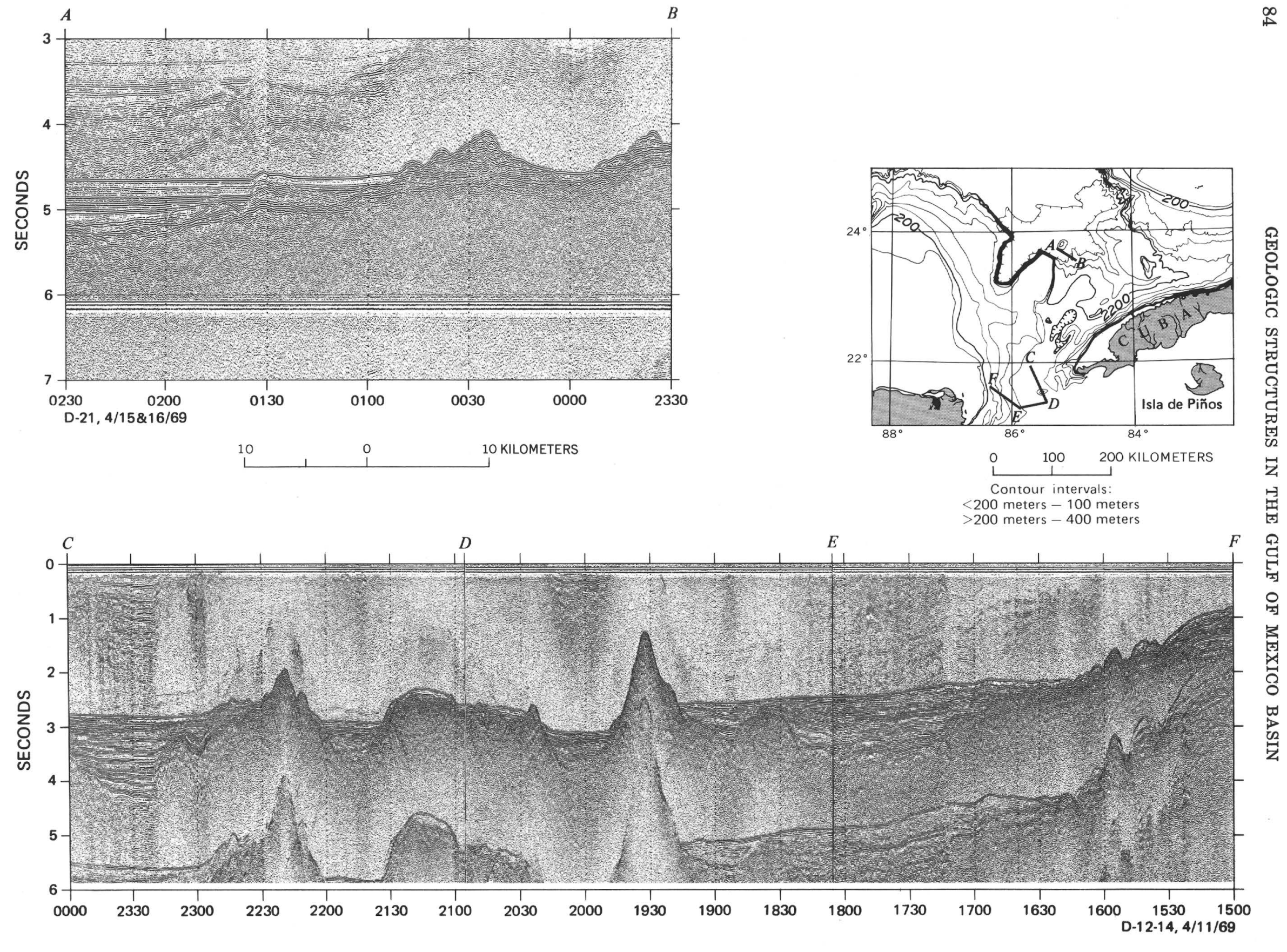
FIGURE 34.-Seismic-reflection profiles, Yucatan Channel and western Straits of Florida. Profile $A-B$ crosses the southern edge of part of the abyssal plain between the Campeche and West Florida Escarpments, where flat-lying turbidite beds thin to a pinchout over the rough topography on the surface of an older unit. The turbidite section has a maximum thickness of $0.55 \mathrm{sec}$ (about $500 \mathrm{~m}$ ) at $0230 \mathrm{hr}$, but thickens to more than a kilometer to the northeast. The age and composition of the older surface has not yet been reported, but it may be equivalent to Cretaceous limestones and cherts encountered in JOIDES holes 96 and 97 reported by Worzel and Bryant (1970).

Profile $C-F$ shows the nature of the ridges that cross Yucatan Channel from Cuba to the margin of the Yucatan Peninsula, where they were described by Baie (1970) as paralleling the coast. Subsequent dredging and profiling by Vedder and others (1971) showed the ridge material to be composed of Upper Cretaceous metamorphic rocks, much like those exposed on Isla de Piños, Cuba (J. G. Vedder, oral commun., 1971). 

